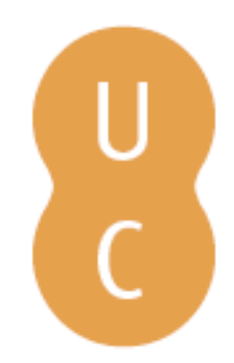

\title{
pommalina
}

\section{Cidadania, políticas públicas e redes sociais}

Autor(es): $\quad$ Portugal, Sílvia, ed. lit.; Martins, Paulo Henrique, ed. lit.

Publicado por: Imprensa da Universidade de Coimbra

URL URI:http://www.uc.pt/imprensa_uc/catalogo/documentos/Pages_from_Ci persistente: dadania.pdf; URl:http://hdl.hand̄le.net/10316.2/2609

DOI: $\quad$ DOI:http://dx.doi.org/10.14195/978-989-26-0222-6

Accessed : $\quad$ 19-May-2017 17:17:24

A navegação consulta e descarregamento dos títulos inseridos nas Bibliotecas Digitais UC Digitalis, UC Pombalina e UC Impactum, pressupõem a aceitação plena e sem reservas dos Termos e Condições de Uso destas Bibliotecas Digitais, disponíveis em https://digitalis.uc.pt/pt-pt/termos.

Conforme exposto nos referidos Termos e Condições de Uso, o descarregamento de títulos de acesso restrito requer uma licença válida de autorização devendo o utilizador aceder ao(s) documento(s) a partir de um endereço de IP da instituição detentora da supramencionada licença.

Ao utilizador é apenas permitido o descarregamento para uso pessoal, pelo que o emprego do(s) título(s) descarregado(s) para outro fim, designadamente comercial, carece de autorização do respetivo autor ou editor da obra.

Na medida em que todas as obras da UC Digitalis se encontram protegidas pelo Código do Direito de Autor e Direitos Conexos e demais legislação aplicável, toda a cópia, parcial ou total, deste documento, nos casos em que é legalmente admitida, deverá conter ou fazer-se acompanhar por este aviso.

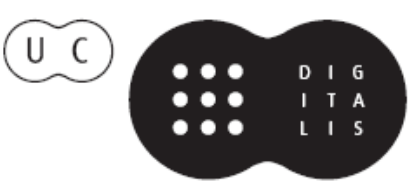


Sílvia Portugal

Paulo Henrique Martins

Organização

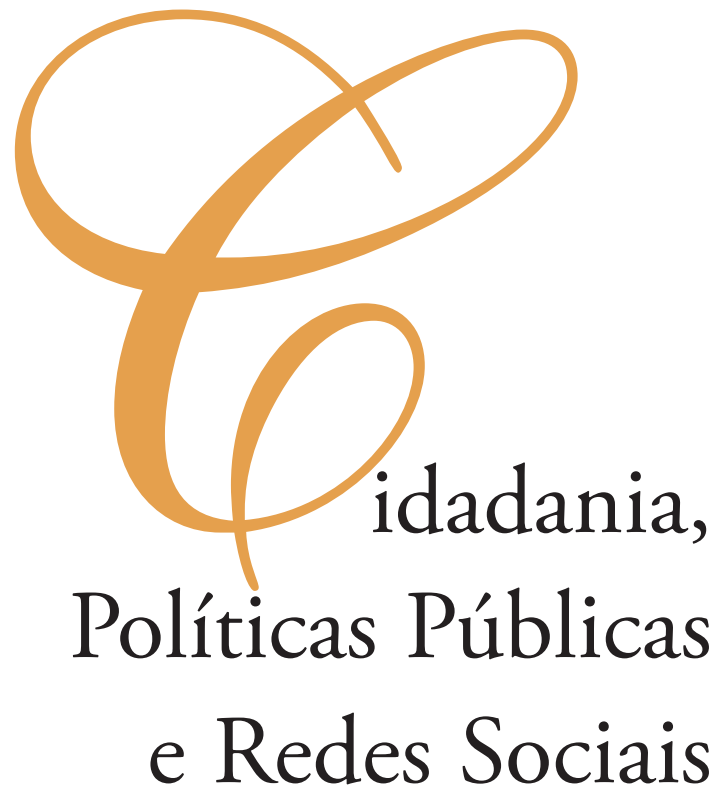


(Página deixada propositadamente em branco) 
iiiiiiiiiie

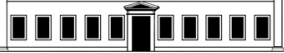

D

0

C

U

M

E

N

T

0

S<smiles>C[C@H]1OCC1(C)C</smiles> 
EDIÇẢO

Imprensa da Universidade de Coimbra

URL: http://www.uc.pt/imprensa_uc

Email: imprensauc@ci.uc.pt

Vendas online: http://www.livrariadaimprensa.com

\author{
CONCEPÇẢo GRÁFICA \\ António Barros \\ INFOGRAFIA \\ Carlos Costa
}

EXECUÇÃo GRÁFICA

Publidisa

ISBN

978-989-26-0073-4

ISBN Digital

978-989-26-0222-6

DOI

http://dx.doi.org/10.14195/978-989-26-0222-6

Depósito LEgAL

$324860 / 2011$

Obra Publicada com o apoio de:

\title{
FCT Fundação para a Ciência e a Tecnologia
}

MINISTÉRIO DA CIÊNCIA, TECNOLOGIA E ENSINO SUPERIOR Portugal

(C) Março 2011, Imprensa da Universidade de Coimbra 
Sílvia Portugal

Paulo Henrique Martins

Organização

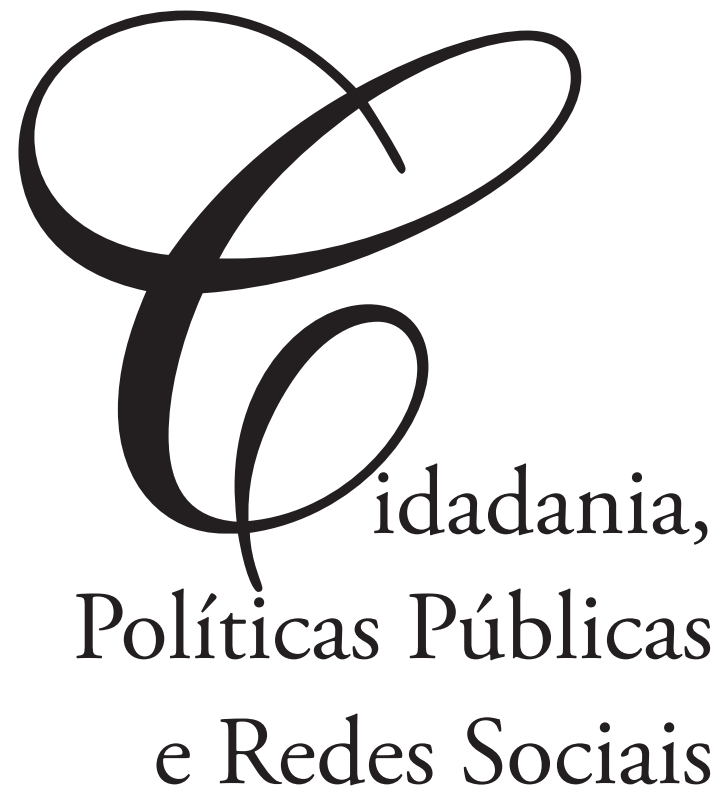


(Página deixada propositadamente em branco) 


\section{SumÁrio}

Introdução: Cidadania, Políticas Públicas e Redes Sociais............................... 7

Sílvia Portugal e Paulo Henrique Martins

O DOM COMO FUNDAMENTO DE UMA CULTURA DEMOCRÁTICA E ASSOCIATIVA.............. 13

Paulo Henrique Martins

CONFIANZA Y DELIBERACIÓN: LAS CONDICIONES ÉTICAS

DE LA PARTICIPACIÓN DEMOCRÁTICA

Cristina Reigadas

Dádiva, Família e Redes Sociais

Sílvia Portugal

A Face Oculta da lua: Reflexốes sobre as Relaçốes

ENTRE O FORMAL E O INFORMAL

Fernando Ruivo

DESPUÉS DE LA DESTRUCCIÓN DEL ESTADO Y DEL FRACASO DEL MERCADO.

EL REDESCUBRIMIENTO DE LA SOCIEDAD, SU CONVERSIÓN

EN “CAPITAL” Y SU PAPEL EN LA LEGITIMACIÓN DE LA DESIGUALDAD

Adriana Marrero

Os Determinantes Sociais de Saúde

Aécio Gomes de Matos

O PAPEl das REDES SOCIAIS NAS POLÍticas SOCIAIS. O CASO dA REDE

Nacional de Cuidados Continuados Integrados

Maria José Hespanha e Pedro Hespanha

Redes Sociais e Saúde Mental

Breno Augusto Souto Maior Fontes

Desafios na Avaliação dos Serviços de Saúde Mental no contexto

DA DESINSTITUCiONALIZAÇÁo

Eliane Maria Monteiro da Fonte

Notas Biográficas dos/As Autores/As 
(Página deixada propositadamente em branco) 
Sílvia Portugal e Paulo Henrique Martins

\section{INTRODUÇÃo \\ Cidadania, Políticas Públicas e Redes Sociais}

As sociedades actuais atravessam profundos processos de mudança, que se relacionam com a globalização, as recomposições do sistema económico, social e político, a entrada de novos actores na esfera pública. Este contexto coloca novos desafios teóricos e metodológicos na agenda de pesquisa das ciências sociais e exige uma reflexão que permita identificar os vectores de mudança, ao nível das diferentes esferas sociais, das instituiçốes estatais às organizaçôes da sociedade civil e às relaçôes informais, da escala supra-nacional ao espaço local.

Este livro apresenta as reflexóes de um conjunto de investigadores portugueses e da América Latina que se questionam sobre estas problemáticas, possibilitando um diálogo entre narrativas disciplinares diversas e o confronto de investigaçóes provenientes de diferentes sociedades. Os textos editados neste volume resultam de um Seminário, realizado em Coimbra, a 26 de Abril de 2007, subordinado ao tema que intitula esta obra - "Cidadania, Políticas Públicas e Redes Sociais". Este encontro foi organizado pelo Núcleo de Cidadania e Políticas Sociais e pelo Observatório dos Poderes Locais do Centro de Estudos Sociais da Universidade de Coimbra (CES), em colaboraçáo com o Núcleo de Estudos sobre Cidadania, Exclusão e Processos de Mudança (NUCEM) da Universidade Federal de Pernambuco, no Brasil. O Seminário reuniu um grupo de investigadores que, após diversos contactos em outros encontros científicos, realizados na Europa e na América Latina, encontrou denominadores comuns nos seus debates acerca das transformaçôes actuais das nossas sociedades.

O conjunto de textos reunidos neste volume pretende contribuir para a construção de novas abordagens sobre os regimes democráticos actuais, a participação cidadã e a produção de bem-estar. Estando atentos aos novos actores e arranjos institucionais que surgem actualmente na esfera pública, e substituem progressivamente as formas de organização societal dominantes do século XX, os autores interrogam velhas e novas teorias e propóem leituras e conceptualizaçóes alternativas, que permitam (re)pensar a tríade Estado-mercado-comunidade.

Dois paradigmas atravessam os diferentes textos - o da dádiva e o das redes sociais. O referencial oferecido por estas duas leituras permite superar uma limitação usual nas ciências sociais: a separação da análise das coisas da análise dos laços. Tradicionalmente, analisa-se, por um lado, o que circula, do ponto de vista económico-social, do mercado, ou da redistribuição estatal e, por outro lado, os laços sociais, a partir de um ponto de 
vista simbólico e relacional, antropológico e psicológico. Os dois aspectos estão separados. É mesmo possível afirmar que esta separação faz parte do ideal da modernidade: de um lado, a dimensão material, do outro, a dimensão afectiva. $\mathrm{O}$ estudo da sociedade a partir da dádiva considera esta separação "uma projecção ideológica" (Godbout, 2000: 14). A perspectiva a partir do dom obriga a juntar os dois pontos de vista, superando a ruptura entre as relaçóes sociais e o seu conteúdo. O objecto de estudo - o que circula - pertence ao mundo económico-social, mas a questáo que se coloca - a sua relaçáo com o laço social resulta duma aproximação simbólico-relacional: "o objecto é económico-social, mas o ponto de vista simbólico-relacional” (Godbout, 2000: 14). Assume-se que todo o objecto económico tem uma dimensão simbólica o que, necessariamente, leva à sua significação social e cultural.

Esta abordagem, desenvolvida a partir do pensamento de Marcel Mauss, constitui uma alternativa aos dois paradigmas dominantes: o individualismo e o holismo, que se apoiam sobre teorias monodimensionais e reducionistas da acção social. O primeiro defende que todas as acçôes, regras ou instituiçôes derivam dos cálculos, mais ou menos, conscientes e racionais, efectuados pelos indivíduos. O holismo (em qualquer das suas versốes: culturalismo, funcionalismo, estruturalismo), pelo contrário, defende que a acção individual se limita a expressar uma totalidade que lhe preexiste e que aparece, assim, como única realidade.

À luz de qualquer destes dois paradigmas a dádiva é incompreensível. No primeiro, dissolve-se no "interesse", no segundo na "obrigação". O paradigma da dádiva não nega a existência de nenhum destes dois momentos - da individualidade ou da totalidade - mas recusa-se a tomá-los como dados. Partindo da interrelação generalizada entre as pessoas, e perguntando-se como se engendram, concreta e historicamente, os dois momentos opostos, faz do dom (do símbolo, do político) o operador privilegiado, específico, da criação do laço social. O paradigma da dádiva reconhece a força dos interesses e a efectividade da obrigação, mas serve-se da dialéctica para pensar estes elementos no quadro de uma teoria pluridimensional e paradoxal da acção.

O interesse sociológico da dádiva para a análise da sociedade contemporânea é reforçado quando agregamos os estudos sobre redes sociais. A visão a partir das redes permite ultrapassar dualidades teóricas e metodológicas características do pensamento hegemónico da modernidade e visibilizar formas sociais, simbólicas e associativas que se encontram obscurecidas nas discussóes acerca da participação e da cidadania, (re)colocando a interacção social no centro do pensamento. De um modo geral, a teoria das redes postula que a análise macro-estrutural deve ser construída sobre fundações micro. Ou seja, o nível interpessoal deve prover bases para explicar actividades e estruturas de níveis mais elevados de agregação. Segundo Mercklé (2004), a teoria das redes constitui uma "terceira via” de compreensão da realidade social - “meso-sociológica”. A sua abordagem tenta responder, simultaneamente, a duas ambiçôes: explicar o comportamento dos indivíduos através das redes em que eles se inserem e explicar a estruturação das redes a partir da análise das interacçóes entre os indivíduos e das suas motivaçóes.

Como afirmam Marsden e Lin, a teoria das redes "oferece novas abordagens para a descrição e estudo da estrutura social e para lidar com o problema complexo de integrar diferentes níveis de análise: o modo como a acção individual cria a estrutura social; o modo como a estrutura social, uma vez criada, constrange a acção individual e colectiva; o modo como as atitudes e comportamentos dos actores são determinados pelo contexto social em que a acçáo ocorre" (Marsden e Lin, 1985: 10). Deste modo, constrói uma "racionalidade 
reticular" que permite olhar o "teatro das circulaçôes" (Parrochia, 2001:17). Ou seja, tal como a abordagem a partir da dádiva, a teoria das redes confere a possibilidade de analisar o espaço relacional, os seus movimentos e o conteúdo desses movimentos - a forma e o conteúdo da relação, simultaneamente.

Segundo Latour, a força da teoria das redes vem da capacidade de tornar visível e descritível o trabalho dos actores (Latour, 1992: 4). É o que pretendem fazer os autores desta colectânea ao visibilizar laços sociais e formas de associação que, de um modo geral, não são considerados relevantes na análise da cidadania e das políticas públicas. Os textos aqui reunidos revelam como os laços primários de parentesco, vizinhança e amizade, as práticas associativas, os arranjos institucionais apresentam desenhos reticulares e dimensôes simbólicas que é preciso valorizar e ter em conta na construção e análise da esfera pública. Os laços primários constroem redes alimentadas por trocas de dádivas materiais e imateriais, apoios, cuidados, afectos e amizades.

No primeiro texto desta colectânea, intitulado "O dom como fundamento de uma cultura democrática e associativa”, Paulo Henrique Martins discute as dificuldades da construção de um pensamento democrático de carácter participativo. Segundo o autor, estas dificuldades não se devem apenas à hegemonia das correntes utilitarista e individualista, mas também à insuficiente compreensão das relaçóes entre simbolismo, poder político e democracia. Para o autor é necessária uma "fenomenologia da percepção" que dê conta dos fundamentos imaginários e normativos da associação primária. $\mathrm{O}$ texto propóe o entendimento da democracia participativa como cultura do dom e do simbolismo e explora o conceito de simbólica associativa como via para aprofundar o conhecimento da acção colectiva, numa perspectiva que privilegie o mundo da vida sobre o mundo dos sistemas.

O capítulo "Confianza y deliberación: las condiciones éticas de la participación democrática”, da autoria de María Cristina Reigadas, aponta no mesmo sentido do anterior, chamando a atenção para a necessidade das políticas públicas promoverem laços de confiança entre os sujeitos. A autora analisa a consolidação das instituiçóes democráticas na América Latina e os debates em torno da qualidade da democracia, identificando as dificuldades colocadas à participação e representação dos cidadãos. Discutindo as difíceis relaçôes entre ética e política, Cristina Reigadas vê na primeira a raíz de uma política emancipatória. Para a autora a participação democrática envolve a conjugação de uma ética das relaçóes interpessoais baseada no respeito, na solidariedade, no reconhecimento e na confiança com uma moral que implica a submissão das posiçóes individuais à crítica e à mudança num processo de abertura ao outro e de generalização de interesses.

O texto seguinte continua a discussão acerca da valorização dos laços sociais e da sua dimensão simbólica. Sílvia Portugal discute, em “Dádiva, Família e Redes Sociais”, o modo como uma abordagem a partir dos paradigmas do dom e das redes sociais pode contribuir para uma reinvenção do político fora dos limites do Estado. Partindo de reflexóes em torno de uma pesquisa empírica sobre a circulação da dádiva no interior da família, a autora sublinha a vitalidade do dom na actualidade e mostra como ele se constitui como um sistema de relaçôes sociais, propriamente ditas, enquanto relações não redutíveis a interesses económicos ou de poder. Analisando o familismo das redes sociais em Portugal, a autora evidencia os desafios colocados por este tipo de laços para a discussáo entre o público e o privado nos países do Sul.

Fernando Ruivo, no capítulo "A face oculta da lua: reflexôes sobre as relaçóes entre o formal e o informal", analisa a coexistência de um modelo hierárquico-formal com um 
modelo horizontal-informal na concepção e execução das políticas públicas. $\mathrm{O}$ autor começa por evidenciar como o mundo informal foi marginalizado e silenciado na análise sociológica, sendo considerado pouco importante para a regulação da vida social, e sublinha alguns contributos fundamentais para a inversão desta tendência. Neste texto, o autor mostra como ambos os sistemas - formal e informal - são faces da mesma moeda, facetas complementares (mesmo que opostas) da mesma realidade, defendendo a ideia de que os processos políticos formais não podem ser devidamente compreendidos sem se prestar a devida atenção à informalidade que contêm. Ruivo usa o conceito de "políticas de informalidade" para esclarecer uma diversidade de situaçôes em que o informal se assume como um instrumento que providencia ao sistema formal um leque de actividades necessárias ao seu funcionamento, concluindo pela necessidade de uma postura analítica que abarque uma cooperação adaptativa entre os dois componentes do sistema - o formal e o informal.

No texto "Después de la destrucción del estado y del fracaso del mercado. El redescubrimiento de la sociedad, su conversión en "capital" y su papel en la legitimación de la desigualdad", Adriana Marrero discute o êxito actual do conceito de capital social na teoria sociológica e na formulação de políticas públicas, mostrando como, na verdade, ele é um "objecto obscuro". Analisando as razóes deste sucesso, a autora evidencia como, apesar dos seus atractivos, as actuais abordagens a partir do conceito de capital social não contribuem para a identificação dos mecanismos de funcionamento e organização da vida social. Segundo Marrero, a teoria do capital social contribui, não para clarificar a análise e a discriminação de elementos importantes para o desenvolvimento das sociedades, mas antes para obscurecer a distinção entre as acçôes do Estado, do mercado e das redes sociais. A autora revela como o principal contributo desta teoria náo é o (re)descobrimento dos laços sociais, mas sim, a atribuição de uma dimensão económica a trocas que têm, na maioria das vezes, um carácter distinto, ignorando as motivaçôes e o significado das acçôes para os actores sociais. Marrero conclui que, sendo fortemente influenciada por pressupostos individualistas e pela economia neo-clássica, a actual teoria do capital social esquece os fundamentos universalistas e os pressupostos igualitários que fundam o Estado moderno e a acção das políticas públicas, celebrando a realidade tal como ela é e legitimando uma ordem social particularista e desigual.

Os textos que se seguem centram a sua análise na temática da saúde, enquanto área fundamental da agenda política actual. Aécio de Matos, no capítulo "Os Determinantes Sociais de Saúde”, mostra como a análise das condiçóes de saúde de uma população extrapola os indicadores sociais típicos relativos ao rendimento, educação e qualidade de vida, para assumir um carácter mais amplo onde se incluem as questóes políticas e o acesso dos sujeitos colectivos aos dispositivos de poder e à tomada de decisão. $\mathrm{O}$ autor analisa a implementação do Sistema Único de Saúde do Brasil - novo modelo de saúde definido pelos princípios de universalidade, equidade e integralidade - para mostrar que o posicionamento das populaçóes no quadro político e, em particular, a sua capacidade para influenciar as decisôes institucionais, tem uma correlação directa com o acesso e a qualidade dos serviços de saúde. Quanto mais isoladas elas estiverem no quadro político, quanto menos capital social elas detiverem, piores são as suas condiçôes de saúde. Neste sentido há que se investir na constituição de sujeitos colectivos, com consciência crítica da sua realidade e da sua relação com o Estado. Segundo o autor esta é a via para a efectividade do SUS no Brasil uma participação social de base comunitária que permita superar os limites da democracia representativa e os desvios da democracia participativa. 
No capítulo seguinte - "O papel das redes sociais nas políticas sociais. O caso da Rede Nacional de Cuidados Continuados Integrados” - Maria José Hespanha e Pedro Hespanha discutem, também, a relação entre saúde e participação, desta vez a partir da realidade portuguesa. Os autores analisam um novo modelo de política social - a Rede Nacional de Cuidados Continuados Integrados - para discutir o modo como diferentes actores se articulam nas respostas aos desafios colocados pela nova realidade demográfica do envelhecimento da população e do aumento de dependentes. A RNCCI é um exemplo da nova geração de políticas sociais que privilegia a parceria do Estado com organizaçóes da sociedade civil, a descentralização do desenho das medidas de política e a sua gestão partilhada pelas instituiçóes locais, a co-responsabilização do prestador e do beneficiário na aplicação das medidas. Os autores mostram, no entanto, que na execução deste programa muitas são as limitaçóes ao efectivo trabalho em parceria e à participação efectiva das famílias e da comunidade, o que os leva ao questionamento desta Rede enquanto tal.

Os dois últimos textos, da autoria de Breno Fontes e Eliane da Fonte, analisam os desafios colocados pela reforma dos serviços de saúde mental e pelo processo de desinstitucionalização em curso na sociedade brasileira. No capítulo intitulado "Redes Sociais e Saúde Mental”, Breno Fontes mostra como, num contexto de reforma do sistema de saúde mental, é essencial considerar a articulação entre o campo médico (instituições e profissionais de saúde), o campo das organizaçóes da sociedade civil (associaçóes e ONGs) e a esfera das redes primárias de sociabilidade (família, amigos, vizinhos). O autor evidencia a importância das redes sociais no quotidiano dos portadores de doença mental e sublinha a necessidade da reforma psiquiátrica integrar esta dimensão. Fontes alerta, no entanto, para as dificuldades que este desafio enfrenta: perante um novo quadro institucional é necessário assegurar que todos os intervenientes (profissionais, associaçôes, comunidade e famílias) têm condiçôes para uma participação efectiva que possa de facto conduzir a novos modelos de integração do doente mental.

Finalmente, no último capítulo - "Desafios na Avaliação dos Serviços de Saúde Mental no Contexto da Desinstitucionalização" - Eliane da Fonte discute os modelos tradicionais de avaliação dos cuidados de saúde, chamando a atenção para a necessidade de construção de instrumentos e indicadores que dêem conta do impacto dos modelos de prestaçáo de cuidados na qualidade de vida dos portadores de doença mental. Indicadores como o número de consultas e de internamentos, remissão de sintomas, número de diagnósticos e de altas revelam-se insuficientes para avaliar os novos serviços criados pela reforma psiquiátrica. A autora analisa o processo de desinstitucionalização em curso no Brasil e o papel estratégico das novas alternativas de base comunitária, chegando à conclusão que os processos de avaliação tradicionais com base no modelo médico e hospitalar não dão uma resposta adequada à realidade actual. Propóe, assim, a integração de variáveis de carácter social para a avaliação dos serviços e da qualidade de vida dos doentes. O desafio consiste em ir além da supressão de sintomas e integrar dimensóes relativas à subjectividade dos doentes e à sua inclusão social. Só assim será possível desenvolver e avaliar políticas de base comunitária. 
Referências Bibliográficas

CAILLÉ, Alain - Antropologia do dom: o terceiro paradigma. Petrópolis: Vozes, 2002.

GODBOUT, Jacques T. - Le don, la dette et l'identité. Paris: La Découverte, 2000.

LATOUR, Bruno - "Introduction". In Centre de Sociologie de L'Innovation, Ces réseaux que la raison ignore. Paris: L'Harmattan, 1992, pp. 1-4.

MARSDEN, Peter V.; Lin, Nan - "Introduction". In Peter V. Marsden; Nan Lin (eds.) Social Structure and Network Analysis. Beverly Hills: Sage, 1985, pp. 9-11.

MERCKLÉ, Pierre - Sociologie des réseaux sociaux. Paris: La Découverte, 2004.

PARROCHIA, Daniel - "La rationalité réticulaire". In Daniel Parrochia (dir.), Penser les réseaux. Seyssel: Éditions Champ Vallon, 2001, pp. 7-23. 
Paulo Henrique Martins

\section{O DOM COMO FUNDAMENTO \\ DE UMA CULTURA DEMOCRÁTICA E ASSOCIATIVA}

\section{Introduçáa $^{1}$}

Neste capítulo propomos que as atuais dificuldades de emancipação de um pensamento democrático de caráter participativo, que são observadas em diferentes contextos, revelam apenas em parte as resistências do pensamento hegemônico utilitarista e mercantilista à adoção de idéias e iniciativas voltadas para uma revalorização da função regulatória do direito entre a faticidade e a validade, como vemos em Habermas (2003). Ou as resistências à adoção de um direito procedimental que permita a transformação do Estado-providência em um Estado-serviço, refazendo a relaçáo sociedade-indivíduo e promovendo melhor redistribuição das riquezas coletivas, inclusão social e maior participação dos atores sociais, como encontramos em Rosanvallon (1995).

No nosso entendimento, tais dificuldades expressam igualmente um outro aspecto que não tem a ver diretamente com a influência do utilitarismo prático e normativo sobre as instituiçóes sociais, mas com a compreensão insuficiente a respeito do modo como o simbolismo aparece no surgimento de alianças e pactos responsáveis pelo trabalho de socialização e formação do caráter e, também, na organização de solidariedades culturais e políticas. Ou seja, apesar do impacto considerável que a descoberta do simbolismo teve classicamente na sociologia, na filosofia e na antropologia, pelas mãos de autores como Mauss (2003), Cassirer (2004) e Lévi-Strauss (2003), não houve ainda o aproveitamento adequado dessas contribuiçóes em termos de repensar as relaçóes entre simbolismo, poder político e democracia. Talvez pelo fato de que os fundamentos simbólicos da vida associativa, dos elementos significativos da consciência coletiva, não sejam visíveis facilmente a partir de uma lógica instrumental, as ciências sociais conhecem dificuldades de incorporar a "fenomenologia da percepção" como base conceitual de suas narrativas críticas.

Sem o entendimento sócio-antropológico adequado a respeito dos fundamentos imaginários e normativos da associação primária entre seres humanos, a ação pública se molda fatalmente em procedimentos administrativos que limitam o horizonte do controle social à aplicação fortuita e pragmática de mecanismos de regulamentação da prática social e de

${ }^{1}$ Faço um agradecimento especial a Maria Cristina Reigadas, cujos comentários foram importantes para melhor sistematizarmos nossa defesa de uma democracia participativa que, sem negligenciar o procedimentalismo, valorize sobretudo o simbolismo, a associação e o dom. 
instrumentalização das instituiçóes que, muitas vezes, apenas ampliam os fenômenos de anomia social. Assim, pela dificuldade de entronizar os fundamentos imaginários e simbólicos da ação humana, as intervenções racionais e planejadas sobre o social tornam-se frequentemente paliativas, superficiais e insuficientes para deter os processos de desorganização, tanto do sistema - a esfera pública e estatal - como do mundo da vida - as práticas do cotidiano -, ao mesmo tempo que terminam favorecendo a dominação da esfera pública pelo sistema mercantil. Nossa hipótese é, pois, que a articulação desta dimensão sócio-antropológica do "mundo da vida", a do simbolismo, com novas açóes públicas que favoreçam o espírito associativo e a esfera pública democrática, é uma tarefa central na discussão sobre democracia, hoje.

Enquanto as atençôes do debate acadêmico voltam-se prioritariamente para o estudo dos procedimentos da participação democrática, dando ênfase no consenso, como faz Habermas, ou no dissenso, como o faz Luhmann (Neves, 2001: 142-145), perde-se de vista que a esfera pública apenas aparece como "mundo comum", "que é comum a todos nós e diferente do lugar que nos cabe dentro dele" (Arendt, 2003: 62), devido a tal esfera se sustentar num magma de significaçóes compartilhadas no mundo vivido e percebido.

Ou seja, embora os estudos das racionalidades procedimentais e sistêmicas sejam importantes para entender a democracia deliberativa, devemos entender que a ênfase excessiva sobre tais racionalidades suprime parte da energia intelectual necessária para se descrever e se explicar o fato de que o fenômeno da participaçáo ocorre primeiramente no plano das significaçóes compartilhadas no plano intersubjetivo, ou do que Charles Taylor define como ontologias morais, que articulam as representaçóes sobre a dignidade, sobre o viver junto e sobre o respeito peculiar aos direitos (Taylor, 2005: 25). Apenas em um segundo momento, depois que se estabelecem alianças e mecanismos de reciprocidade entre as subjetividades presentes no contexto da vida, pode a dádiva emergir como valor moral revelador da práxis política, das regras de solidariedade e dos procedimentos jurídicos e administrativos que asseguram a validade da justiça e do direito no plano formal.

Neste texto, defendemos, em suma, a hipótese de que a ausência de um aprofundamento dos fundamentos subjetivos dos processos de constituição de alianças e solidariedades repercute negativamente na adoção de iniciativas coletivas e cívicas, em geral, e de políticas estatais, em particular, que possam fortalecer a estruturação de uma esfera pública democrática e participativa, ancorada num direito comunitário e de propriedade mais igualitário, a médio e longo prazo. Tal ausência de aprofundamento desta compreensão do simbolismo da ação social inibe, por conseguinte, a tarefa de reorganizar a representação política pela ótica de uma responsabilidade fundada na permanência, baseada em uma transcendência temporal que extrapole a duração de vida dos mortais e integre uma compreensão ética menos imediata e mais alongada da vida (Arendt, 2003: 64; Jonas, 1997: 14). Pois, na medida em que a ação política, em geral, e a ação estatal, em particular, se limitam a uma "metafísica da presença" que condiciona o campo dos movimentos político-estratégicos à objetividade social imediata, perde-se de vista a importância da dualidade, do antagonismo e do conflito na produçáo do mundo da vida (Mouffe, 1994: 12).

No nosso entender, a revalorização conceitual e política do local em sociedades complexas como as atuais, deveria, portanto, considerar as diferenças culturais e sociais como pressupostos do reconhecimento moral, do equacionamento das tensóes entre o público e o doméstico (Arendt, op. cit.: 51), mas também da resolução das tensóes entre a igualdade e o pluralismo (Walzer, 2005: 84-85). Não basta, logo, para se entender a democracia plu- 
ralista, reconhecer os antagonismos com meras diferenças, como tem feito o liberalismo - e também J. Habermas com sua tese sobre o consenso -, mas de entender que a distinção entre o inimigo e o adversário não é algo menor na estruturação do mundo da vida. Tal distinção, explica Mouffe, permite entender que "no interior do nós que constitui a comunidade política, o opositor não deve ser considerado um inimigo cuja existência deve ser eliminada mas um adversário cuja existência é legitima” (Mouffe, 1994: 14). A partir daí, a autora valoriza a distinção entre o antagonismo (relação ao inimigo) do agonismo (relação ao adversário) que é uma categoria central na sua tese acadêmica.

Certamente, o reconhecimento do agonismo como pressuposto de organização da política coloca em cheque as teses de que o pluralismo democrático nasce ou do consenso (J. Habermas) ou do dissenso (N. Luhmann). Diversamente, o agonismo revela diretamente a presença do dom, de sistemas de prestaçóes e contraprestaçôes, que escapam a toda instrumentalização para revelar a expressividade congênita do ser humano na sua vivencia grupal, onírica e material. Urge considerar, portanto, na discussão sobre a democracia plural e sobre a formação da esfera pública democrática, as condiçóes pelas quais os atores redefinem suas hierarquias de valores, em geral incorporadas inconscientemente, para se tornarem cidadãos culturalmente visíveis e portadores de açóes solidárias valorizadoras do bem público.

Com este propósito, buscamos aprofundar neste texto o conceito de simbólica associativa para explorar seu interesse em termos de ação coletiva e esfera pública. Isto implica compreender os fundamentos morais que condicionam os desejos dos indivíduos de estarem juntos e de partilharem iniciativas comuns, como se fosse algo absolutamente natural. De fundarem experiências de dignidade na vida cotidiana, que permitem não apenas direitos objetivos mas, sobretudo, direitos subjetivos, para cada indivíduo e grupo, como acontece na modernidade ocidental (Taylor, op. cit.: 30). Tais experiências redundam em resoluçôes culturais mais complexas do dom, que deixa de se referir apenas a pactos comunitários, abrindo-se para o anonimato (Godbout em colaboração com Caillé, 1998: 81-96) como é o caso da dádiva entre estranhos e para o individualismo (Godelier, 2004: 12).

Nosso interesse é trazer uma discussão mais efetiva sobre o simbolismo, dando ênfase particular à contribuição de Marcel Mauss (2003), cuja noção de "fato social total" tem um valor heurístico particularmente pertinente para se compreender a relaçáo subjetiva entre cultura e política. Por fim, tentaremos desenvolver algumas reflexóes relativas à importância de uma cultura do dom fundada nas alianças primárias, que nos parece um desafio necessário para se entender a emancipação de novas esferas públicas híbridas e participativas, sem as quais a vida associativa é um projeto precário.

\section{O embaraço democrático}

Fóruns sociais, orçamentos participativos, conselhos municipais, assembleias e plenárias, mobilizaçóes locais de grupos de mulheres e de orientaçóes sexuais diversificadas, movimentos étnicos, nacionalistas, culturais e religiosos, tudo isso compóe o quadro que tem sido conhecido como democracia participativa nas duas últimas décadas. Acreditou-se que a institucionalização dos movimentos sociais, o crescimento do número de organizaçóes não-governamentais transnacionais, o surgimento de governos de esquerda mais sintonizados com as novas demandas sociais e culturais, e as manifestaçóes de rua nas grandes 
cidades, seriam sinais de que estaria para acontecer, brevemente, uma mudança importante nas lutas anti-globalizaçáo e na implantação de um socialismo promissor ancorado na democracia participativa.

As primeiras avaliaçóes sérias sobre o assunto ${ }^{2}$ demonstram que foram importantes os ganhos resultantes de mobilizaçóes sociais e culturais voltadas à criação de novos mecanismos de participação e de reconhecimento identitário, no âmbito do planeta, das naçôes, dos municípios e comunidades. A cada dia, surgem novas experiências que sugerem estar em curso uma grande reforma das instituiçóes sociais e culturais, com o surgimento de redes associativas que estimulam a criatividade e a solidariedade dos atores e agências no plano horizontal.

O preocupante, porém, é observar que essas reformas não parecem apontar necessariamente para o fortalecimento de um novo tipo de regime democrático, legitimado em uma ampla rede de solidariedade estendida nos planos local, nacional e planetário. Pelo contrário, ao se analisarem diferentes experiências, tidas como exemplares, percebem-se indícios preocupantes de um mal-estar crescente, revelado por sinais como a fragmentação dos direitos de cidadania, o aumento das iniquidades sociais e das distâncias entre os mais ricos e os mais pobres, a manipulação generalizada da opinião pública pelo marketing eleitoral, o desinteresse crescente dos jovens pela participação direta na vida política. Em conjunto, tais fenômenos sugerem que o princípio do igualitarismo universal próprio, a experiência republicana e a preservação do ideal de um bem comum superior à soma dos bens individuais, estariam sendo ameaçados em vez de preservados e ampliados. Se a desconstrução do universalismo é importante, por um lado, para se fazer a crítica do racionalismo iluminista, por outro, ela se torna um problema no momento em que o excesso de relativismo ameaça, como diz Mouffe, a permanência de um projeto político de realização da igualdade e da liberdade para todos (Mouffe, 1994: 31).

Ilustremos esta discussão com uma experiência concreta, a do orçamento participativo (OP) na cidade do Recife (Brasil), que vem se constituindo numa bandeira importante do governo do Partido dos Trabalhadores (PT), desde 2002. Analisando-se o quadro de distribuição de recursos, percebe-se que os grupos com mais sucesso prático na apropriação dos recursos públicos são aqueles formados por mulheres, por negros e por animadores culturais, revelando a força organizadora desses grupos nos processos decisórios locais. As pressôes exercidas por grupos e mobilizaçôes locais, sobre os gestores públicos, resultam numa distribuição assimétrica e desigual de bens coletivos entre os atores institucionais envolvidos, o que escapa, pelo menos teoricamente, ao ideal de um igualitarismo que beneficie a todos. Isso estabelece uma situação paradoxal.

Por um lado, tais pressóes são legítimas dentro de uma ótica utilitarista liberal na qual cada um, coerente com o princípio da liberdade, receberia aquilo que corresponde às finalidades perseguidas a partir do próprio interesse. Por outro, tal mecanismo gera novas desigualdades que levam a democracia, como experiência de gestáo igualitária, livre e voltada para o bem comum e público, a perder credibilidade em favor de um sistema hierárquico desigual de distribuição de renda. Conclui-se, entấo, que estas assimetrias no

2 A Revue du Mauss organizou um número especial, intitulado 'Alter-démocratie, alter-économie: chantiers de l'espérance' (2005), que contém reflexôes interessantes sobre a importância de se avançar num novo debate sobre a democracia, devido aos mecanismos da democracia representativa não bastarem para garantir os princípios de uma igualdade universalista. 
funcionamento de programas descentralizados, como o orçamento participativo, não são meros acidentes de percurso resultantes da tensão entre redistribuição e reconhecimento. Elas revelam também a presença e/ou sobrevivência de um sistema de dominaçáo voltado para a manipulação mesmo que involuntária da representação, que se camufla no discurso da participação democrática ${ }^{3}{ }^{4}$.

As experiências sugerem haver no ar uma ameaça de impasse da luta democrática, realçando problemas antigos - as dificuldades crescentes de regulação das diferenças entre os mais ricos e os mais pobres nas democracias modernas -, e revelando novos problemas como os obstáculos múltiplos à manutenção de uma política de redistribuição de bens coletivos que preserve a perspectiva do interesse público e comum -, num contexto de forte diversificação identitária.

As teorizaçôes em curso sobre as experiências de democracia participativa deixam perceber um problema teórico bem mais geral. Observa-se, assim, em escala planetária, incluindo a América Latina, a emergência de uma tendência particularista da luta pela igualdade (iguais pela similaridade identitária) que vem tomando a dianteira dos que defendem a representação universalista tradicional da igualdade (iguais pela similaridade jurídica), que vem sendo objeto de novas teorizaçóes. Alain Caillé vê os processos em curso como expressôes de uma "parcelarizaçáo" sem limites da política, ou seja, o surgimento de um movimento de multiplicação ilimitado de demandas por participação, que é preocupante por comprometer o valor da universalidade. O risco político da excessiva demanda por direitos setorializados - que não mais se pautam pelas referências da igualdade universal, mas pelos interesses grupais localizados - é de se sair da democracia para entrar num sistema parcelado, "que oscila na ilimitação pela via da exaltação do heterogêneo e pelo sacrifício das liberdades coletivas em favor da liberdade individual, que é hipostasiada e fantasmatizada" (Caillé, 2006a: 92, tradução nossa). O dilema central que se coloca no presente momento não é, então, entre mais ou menos participação e representação, porém entre a democracia participativa e a diluição das experiências democráticas, num jogo de fragmentação da memória do igualitarismo universalista.

Por outro lado, esta "parcelarização" e a descrença crescente a respeito das instituiçôes democráticas reforçam os interesses privados e especulativos, facilitando o avanço do projeto neoliberal. Este, pelo mesmo movimento que dissemina o utilitarismo mercantil e o individualismo consumista, aprofunda as tendências de desigualdade social, de ampliação das fraturas culturais e identitárias e de dissociação dos laços de solidariedade nos âmbitos da comunidade e da cidadania, permanecendo a família um refúgio afetivo-cognitivo dos indivíduos num mundo fragmentado.

${ }^{3}$ Na sua tese de doutorado sobre a cidade do Recife, Paul Cary observa que o OP desta cidade parece mais a contrapartida de uma obrigação moral dos dirigentes do Partido dos Trabalhadores que a expressão de uma confiança concreta nas capacidades das classes populares de se autogovernarem, o que, conclui ele, contribui para um certo mal-estar resultante do fato de que se estabelece uma nova separação hierárquica entre dirigentes e administrados (Cary, 2005: 227).

4 As dificuldades de emancipação da democracia participativa não sẫo apenas vivenciadas pelos países do Sul. Trata-se de um fenômeno muito mais geral ligado ao aumento das desigualdades sociais, tanto nos países ricos como pobres. François Dubet, ao analisar a situação da escola na França, por exemplo, observa que ela vem contribuindo para aumentar as desigualdades naquele país (Dubet, 2003: 45). Este tipo de problema vem se verificando de modo mais ou menos intenso em escala planetária. 
Evelina Dagnino (2004: 99) denomina de "confluência perversa” um fenômeno recente de cooptação de entidades e grupos da sociedade civil pelo Estado, servindo à adaptação do projeto neoliberal em contextos de capitalismo periférico, como o brasileiro. Ela explica que a inserção institucional de setores da sociedade civil visando uma atuação conjunta com o Estado, com a finalidade de aumentar o seu potencial participativo, tem contribuído para apagar distinçóes e divergências e gerar um vocabulário comum de procedimentos e mecanismos institucionais que enfraquecem a dimensão política da cidadania e da solidariedade (Dagnino, 2004: 108). Confluência perversa expressa, então, um processo de centralização de decisóes que desfaz os mecanismos de mediação institucionais e políticos que possibilitam a existência efetiva do direito público, em nome da necessidade de assegurar a distribuição de serviços e benefícios sociais exigidos por demandas particularizadas e utilitárias. Confluência perversa designa o deslocamento de significados, produzido pelo neoliberalismo no Brasil e em sociedades com características similares, o qual exalta a presença de uma sociedade civil ativa, não para garantir o projeto participativo mas justamente o contrário, para fragmentar a memória institucional da igualdade universalista da ação pública em favor da lógica dos ganhos e da especulação econômico-financeira.

Uma das teses que pretendemos desenvolver neste texto é, assim, de que o atual embaraço democrático tem como uma das explicaçóes centrais, no debate acadêmico, a indefinição conceitual do termo democracia participativa. Por um lado, esta indefiniçáo tem um caráter histórico: ela revela um dilema subjacente - aquele entre democracia representativa (e o poder da representação) e democracia direta (e o poder da identificação) -, devidamente lembrado por Jacques Godbout (2005). Por outro lado, tal indefinição tem um caráter semântico: a redução do termo participação à mobilização intencional e direta de grupos organizados em torno de temas culturais e sociais.

Este reducionismo do termo participação deixa de lado o fato de que a prática associativa pressupóe que os indivíduos e agentes sociais, presentes na ação, compartilhem de significados comuns ou próximos a respeito da vida comunitária ou do bem comum e público, algo já entendido há um século pelos autores pragmatistas (Cooley, 1966; Dewey, 1997). Neste texto vamos propor, então, que uma das saídas para repensarmos os impasses acerca da definição de democracia participativa é o de focalizar teoricamente, com mais intensidade, o simbolismo, de modo a que possamos entender a democracia primeiramente como originada nas experiências primárias do dia a dia, como o fizeram os pragmatistas, experiências que, lembra Chanial (2001), têm estreita correspondência com o sistema da dádiva.

Compreender a democracia participativa primeiramente como uma prática cultural e de associação, a qual se revela quando são dadas as condiçóes básicas para emergir o sentimento de pertencimento grupal, é uma forma de se priorizar o mundo da vida sobre o dos sistemas. Mas esta alternativa é a única maneira de se valorizar um olhar sobre o cotidiano que não se restrinja ao microssocial, abrindo-se ao macrossocial, como o fez Mauss com a tese do "fato social total". E este olhar sobre a realidade apenas emerge quando os indivíduos e agentes coletivos compartilham símbolos comuns no trabalho, na política e na vida cotidiana, símbolos que são por natureza dons e alianças (Caillé, 2000).

Pretendemos demonstrar que o salto teórico qualitativo em termos do conceito de democracia participativa apenas pode ser alcançado se visualizarmos a participaçáo coletiva na política como prática cultural, ou, mais precisamente, a democracia participativa como cultura do dom, da aliança e da solidariedade em torno do bem comum e, no caso das sociedades modernas, do bem público. Aqui, não é a ação intencional ou a vontade de 
poder de alguns indivíduos, mas a vivência coletiva de certos simbolismos que engendra a associação e o dom, tanto no espaço privado como no público ${ }^{5}$.

Pela consideração do dom como simbolismo, acreditamos ser possível avançar numa nova relação entre democracia e ação pública. Isto é, as possibilidades de se repensar a ação pública a partir das novas exigências de reconhecimento e de participação apresentadas pelos atores-autores da sociedade civil, devem implicar em se considerar com atenção, ao mesmo tempo e com a mesma valoração, o direito e a prática; tanto as mobilizaçóes concretas dos cidadáos em torno de símbolos compartilhados no imaginário social e político, como o imperativo da universalidade de valores e regras plurais, que se voltem para resguardar a liberdade e a igualdade de todos, como sugere com pertinência Mouffe (1994: 31).

Seguindo esta linha de raciocínio, nossa hipótese é de que a institucionalização da democracia participativa de forma mais permanente, depende do surgimento de uma cultura do dom e da associaçáo, a qual, na verdade, para sermos mais precisos, deveria ser tratada no plural, como culturas do dom. O sistema do dom, dos movimentos de doaçóes, recebimentos e retribuiçóes que estão presentes em todas as sociedades humanas já existentes, como observa Marcel Mauss no seu texto Ensaio sobre o dom: forma e razáo da troca nas sociedades arcaicas, de 1924, é o referente básico de que nos servimos neste trabalho para desenvolver nossa reflexão sobre as perspectivas de uma cultura democrática participativa de base associativa, pluralista e universalista. Açôes mais efetivas a médio e longo prazos e voltadas para a emancipação de uma democracia participativa de caráter associativo, deveriam considerar a importância do dom na prática cotidiana. Não apenas como uma experiência pontual, limitada à família ou grupos de amigos, mas como um modo efetivo de se viver generosamente e reciprocamente a si mesmo, ao outro e à comunidade.

Contudo, para clarearmos esta reflexão, devemos esclarecer, primeiramente, o que entendemos pelo termo cultura, de modo a defendermos, em seguida, o valor do dom como cultura e a democracia participativa como cultura do dom.

\section{Cultura, dom e democracia}

Nos limites do presente texto, nossa preocupação é de explorar o uso do simbolismo dentro da sociologia política e dos estudos sobre democracia, a qual pode ser resumida na seguinte questão: como podemos definir uma cultura do dom e do simbolismo, que nos auxilie no entendimento de uma democracia participativa, fundada na aliança e solidariedade, no atual contexto de fragmentação social e diversidade identitária? No nosso entendimento, os estudos maussianos nos oferecem elementos importantes para avançar nesta discussão e para sairmos dos limites da abordagem procedimentalista da política, que prendeu nossa atenção na primeira parte deste artigo.

Em primeiro lugar, é necessário dizer que, na perspectiva de Mauss, a compreensão da democracia participativa, como cultura do dom, deve considerar que as práticas culturais de base associativa surgem, necessariamente, das relações interpessoais e dos sistemas de prestações e contraprestaçóes fundados na doação, no recebimento e na retribuição de bens

\footnotetext{
${ }^{5}$ Este novo tipo de prática cultural surge paulatinamente, como já vimos, nas experiências associativas territorialmente localizadas, nos bairros e comunidades e, também, em novos espaços de significação da política, como os conselhos municipais e as mobilizaçôes políticas espontâneas de ruas.
} 
simbólicos e materiais, envolvendo comunidades, grupos e famílias. A dimensão do simbolismo é fundamental na reflexão sobre a troca em Mauss, diz Merleau-Ponty, na medida em que apenas ela permite o acesso ao outro, a compreensão do outro, sem que sacrifiquemos nossa lógica ou a lógica do outro (Merleau-Ponty, 1960: 124). Diferentemente de leituras sobre o simbolismo, que o condicionam à dimensão fonética e formal da linguagem, aquela proposta por Mauss no Ensaio sobre a dádiva (Mauss, 2003) tem, claramente, um valor prático associado à aliança entre os homens, aos seus vínculos ${ }^{6}$.

Merleau-Ponty esclarece ainda, a respeito de Mauss, em seu texto "De Mauss à Claude Lévi-Strauss", que "concebendo o social como um simbolismo, ele criou as condiçóes para se respeitar a realidade do indivíduo, aquela do social e a variedade de culturas, de modo que não permanecessem impermeáveis umas à outras" (Merleau-Ponty, 1960: 126, tradução nossa). A compreensão do social como simbolismo permite superar os modelos teóricos dicotômicos e lineares, para se entender as partes em interação a partir de uma totalidade mítica invisível, de uma espécie de síntese primeira que funciona como cimento afetivo e significativo dos múltiplos eventos que permeiam o contexto e que se articulam, apesar de suas variedades. ${ }^{7}$

Em segundo lugar, podemos propor que o entendimento da democracia participativa, como cultura do dom, se explica pelo fato de que os ideais morais de bem comum e público, de igualdade e de justiça social, não podem ser construídos apenas pelas racionalidades dos atores sociais consideradas como objetos separados. É fundamental entender-se que a própria idéia de participação coletiva tem que ser experimentada primeiramente como um simbolismo, como um imaginário instituinte coletivo, antes de aparecer como um vivido particular qualquer. Os atores se tornam autores na medida em que partilham, voluntária ou involuntariamente, certos símbolos, representaçôes e crenças.

Ora, se o símbolo é o próprio dom e se reveste da forma de um sinalizador de alianças, ele é a condição necessária para que a coletividade experimente sentimentos e emoçóes comuns a respeito da vida e da morte, da liberdade e da obrigaçáo, do interesse e do desinteresse. Ou seja, se os dons simbolizam a aliança (Caillé, 2000: 203-206), o sentimento da participação democrática não pode resultar de nenhuma decisão calculada de indivíduo ou grupo isoladamente, mas de uma vivência comum do simbolismo. Tal compreensão da realidade humana como um sistema simbólico nos permite falar de um paradigma do dom, forma de saber e de ação, no interior da qual se forjam as alianças e o que estamos denominando de cultura do dom.

Nossa hipótese é de que uma cultura democrática participativa inédita deveria ser o desdobramento dessas experiências originárias da dádiva, ou seja, das tendências dos indivíduos

6 Isso diferencia, desde já, uma definição operacional de cultura fundada numa sociologia do ator, ou do sujeito, por um lado, de uma definição de cultura fundada na sociologia do vínculo, sobre a qual se apoiam os estudos sobre o dom, por outro. Nesta sociologia do vínculo o sujeito existe não como projeto cognitivo de indivíduos ou grupos, mas como resultado das modalidades de circulação coletiva de prestações e contraprestações nem sempre objetivadas, isto é, muitas vezes inconscientes, envolvendo a totalidade dos membros da comunidade, mesmo que frequentemente tenha ressonância diferenciada sobre os mesmos.

A noção de "hau" à qual se refere Mauss no Ensaio, quando busca descrever o espírito das coisas dadas em sociedades tradicionais estudadas, tem este valor de síntese organizativa. Mas é um erro, lembra Caillé (2000: 216), reduzir esta totalidade organizativa a leis estruturalistas de trocas, como fez Lévi-Strauss, o que impede se compreender que as funçôes simbólicas organizativas variam de cultura para cultura e como elas são refeitas em sociedades complexas como as atuais para dar nascimento a novas estruturas de significação histórico-cultural. 
e grupos se associarem de algum modo em torno de funçôes simbólicas que dão sentido à vida comunitária e associativa. Tais funçôes simbólicas são flexíveis e dependem dos contextos históricos e culturais particulares, não se reportando, por conseguinte, apenas ao mundo do trabalho ou da ação política organizada, mas ao conjunto de atividades presentes no dia-a-dia, como jogos, festas e gentilezas ${ }^{8}$. O diferencial oferecido pela cultura da dádiva para o entendimento das sociedades complexas e contemporâneas, é o de que o sistema de prestaçóes coletivas tende a ultrapassar as fronteiras do imaginário comunitário local tradicional, desenraizando os indivíduos, favorecendo novas formas de relação fundadas no anonimato (Godbout e Caillé, 1992), e incorporando esses indivíduos em esferas políticas que se translocalizam e se transnacionalizam.

O espaço tradicional da cultura do dom tinha um caráter mais propriamente obrigatório, dado pelo modo como o fato religioso condicionava a difusão do simbolismo nas festas, rituais e magias. No contexto de sociedades complexas, todavia, os membros da sociedade são convidados a definirem seus próprios sistemas de troca (Merleau-Ponty, op . cit.: 141), o que amplia grandemente o valor da liberdade individual. A cultura do dom contribui, na contemporaneidade, para refazer as obrigaçóes coletivas a partir da valorização de uma experiência de libertação do imaginário social pela individualização (Godelier, 2004) e surgimento de um self expressivo complexo (Taylor, 2005). Neste novo contexto, o simbolismo se revela mais ágil na função de significar novos sentimentos e motivaçóes coletivas voltadas para a associação. Todavia, os novos padróes de significação que os grupos emergentes criam, tanto podem apontar na direção de uma cultura de solidariedade ampla, como os movimentos pela paz ou pela preservação do meio ambiente, como podem, no sentido contrário, apontar para açóes de violência aberta contra os padróes culturais tradicionais. O primeiro desses padrôes, podemos representar, metaforicamente, pela imagem de uma pomba branca, o segundo, pela de um revólver.

A cultura do dom como base da democracia participativa deve implicar, por conseguinte, a decisão política de criação de significados coletivos que permitam articular o movimento de diversificação e de libertação de movimentos gerados pelos choques incessantes de culturas em sociedades complexas. Deve estimular a interiorização de regras morais e valores emocionais que favoreçam a solidariedade grupal e a prática da negociação discursiva e afetiva?. $\mathrm{O}$ vínculo associativo não se gera nem por baixo - a partir da perspectiva de indivíduos separados -, nem por cima - a partir da perspectiva de uma totalidade social separada -, mas a partir do seu meio, "horizontalmente, em função do conjunto de inter-relaçôes que ligam os indivíduos e os transformam em atores propriamente sociais” (Caillé, 2000: 19).

$\mathrm{Na}$ ótica de uma cultura do dom o fundamental é verificar que iniciativas políticas, jurídicas e institucionais devem ser forjadas para surgir uma democracia participativa e associativa autêntica, para nascer uma aliança que possa canalizar - sem se fragmentar - as tensôes horizontais e verticais - culturais, históricas, religiosas e morais -, geradas pelas mo-

\footnotetext{
${ }^{8}$ Esta ideia da sociedade como fato social total é o grande trunfo da contribuição de Mauss. Nele, a cultura do dom deve ser compreendida como representaçóes coletivas intrinsecamente simbólicas que se apresentam como fato social total. Nelas se incluem nossas representaçôes atuais de democracia participativa.

9 O paradigma do dom é o sistema de conhecimento mais amplo que envolve a cultura do dom e que permite compreender a realidade social de modo relacional, incluindo, pela aliança, as dimensóes macro e micro, subjetivas e objetivas e, a partir da simbólica da associaçáo, o surgimento de experiências voltadas para o bem comum, para o público.
} 
bilizaçôes dos indivíduos e grupos sociais no calor do choque cultural. O desafio, aqui, é o de se conceber uma idéia de cultura democrática de base associativa que assegure no plano simbólico a criação de um sistema normativo, moral, jurídico e institucional de caráter coletivo, universal e obrigatório, mas aberto ao mesmo tempo à diversidade, à singularidade e à liberdade. Isto é, que estabeleça uma prática institucional e política, plural e dialógica, onde o interesse deve ser mediado pelo desprendimento, onde o bem individual deve se submeter ao bem comum.

As disputas interpessoais geradas no plano das experiências diretas e locais, nos bairros, nas comunidades, nas assembléias e nos fóruns, não são casuais. Elas apontam para a existência de um conjunto de novas significaçôes que informam as práticas discursivas - as rivalidades, as celebrações, as solidariedades. Como também indicam novas modalidades de resistência geradas a partir de sentimentos de exclusão, de não reconhecimento e de abandono que provocam o surgimento de simbólicas associativas de base corporativa e particular. A partir de certo momento tais práticas podem se tornar mesmo anti-democráticas, comprometendo a manutençấo dos valores de uma cidadania equitativa e universal. Independentemente dos significados morais que adquirem as novas representaçóes profanas e sagradas da vida política, o fato é que elas são necessariamente reguladas por dispositivos - memórias, crenças, valores que favorecem o surgimento de novos lugares de enunciação e exercício do poder, regidos pelas diversidades identitárias e culturais. As novas narrativas simbólicas contribuem, tanto para promover diálogos diferenciados e legitimados pelo respeito à diferença e pelo ideal de preservação da universalidade como, no sentido contrário, para estabelecer padróes individualistas, particulares, que comprometem as bases da democracia participativa. Esta segunda tendência vem se espalhando no momento presente, mas nada indica que ela tenda a comprometer estruturalmente a memória construída sobre democracia e participação.

Em outros termos, propomos o entendimento da democracia participativa como experiência coletiva pulsante, isto é, como uma prática cultural e associativa de valor público e com potencial deliberativo, constituindo um salto teórico inestimável para superar o dilema atual entre democracia representativa e democracia direta, para ultrapassar o abismo atual entre ação por representação e ação direta por mobilização cívica.

Enfim, o projeto neoliberal não pode sustentar sua validade quando o enfocamos a partir de uma crítica cultural que permita demonstrar que a identificaçáo do fenômeno da cultura ao consumismo utilitário é um equívoco teórico, que esconde o fato de que os interesses de satisfação imediata, como o do consumo, não são naturais, mas instaurados simbolicamente. Como diz Sahlins "as atividades práticas possuem sempre um valor simbólico e os efeitos materiais, inclusive os da política, sempre se referem a um significado e a uma localização cultural" (Sahlins, 2003: 205-206). Este é o contexto em que aprofundaremos a compreensão da importância da cultura do dom para o surgimento de novas esferas híbridas, públicas e participativas.

\section{A cultura do dom e o surgimento de uma nova esfera pública participativa}

É importante articularmos esta discussão sobre uma cultura democrática e participativa fundada no dom com a instauração de políticas públicas que favoreçam o surgimento de experiências coletivas voltadas para a solidariedade: na política, na economia, nas práticas culturais e sociais. Ou seja, um novo fato moral associativo que contribua para mobilizar 
as vontades e desejos múltiplos, trazendo à tona as diferenças e singularidades, mas estimulando a negociação, a aliança e a associação, favorecendo, como propuseram os filósofos pragmatistas norte-americanos John Dewey (1997) e Charles Cooley (1966), a opinião pública e o espaço público.

Mas o novo fato associativo não pode prosperar com sucesso caso náo entendamos que a liberdade individual na contemporaneidade tem um impacto subversivo sobre o simbolismo. Merleau-Ponty compreendeu com clareza este fenômeno de estilhaçamento das estruturas simbólicas tradicionais nas sociedades complexas contemporâneas. Tal fenômeno é aquele em que os indivíduos são levados a definirem seus sistemas simbólicos a partir de suas próprias motivaçóes e experiências. Diz ele que "esta subversão significa ganhos imensos, possibilidades inteiramente novas, como, por outro lado, perdas cujo valor precisam ser mensuradas, riscos que começamos a constatar. A troca, a função simbólica, perdem sua rigidez, mas também sua beleza hierática; à mitologia e ao ritual substituem a razão e o método, mas igualmente um uso profano da vida, acompanhado, aliás, de pequenos mitos compensatórios sem profundidade" (Merleau-Ponty, op. cit.: 141).

As novas formas societais - interpessoais, intergrupais ou intercomunitárias - fundadas nas lutas pelo reconhecimento, pela inclusão, pelo respeito e pelas novas posiçóes identitárias, constituem a trama central das tentativas de culturas democráticas participativas autênticas, que resultam dessas novas estruturas simbólicas. Mas, para que estas culturas particulares se generalizem, servindo de base para modelos organizacionais mais amplos para culturas gerais - e para um novo sistema de direito associativo de base comunitária ampliada, é necessário açóes públicas que valorizem as simbólicas associativas que funcionam como cimento afetivo daquelas formas societais. O processo de criação cultural de uma nova forma de fazer política, a partir das sociabilidades primárias, revela as tramas vividas pelos sujeitos sociais no bojo de choques culturais cruzados, de uma parte, entre o tradicional e o moderno, de outra, entre o nacional e o global. A inovação cultural contemporânea manifesta, por sua vez, novas modalidades de trocas, de dádivas positivas e negativas, que são recriadas e recicladas pelos indivíduos a partir das rupturas de antigas crenças e valores e do surgimento de novas modalidades de ação.

Certamente, o clima sócio-cultural é efervescente e marcado por conflitos, rivalidades e generosidades, dentro de diferentes estruturas de poder que escapam ao controle de quaisquer poderes centralizados, como é o caso do Estado. Isto desperta uma tensão inevitável entre ação direta e ação indireta, entre democracia primária e democracia secundária, provocando deslocamentos de sentidos e surgimento de novas significaçóes coletivas que se expressam em normas, valores, crenças e regras sociais que são traduzidas nos espaços entre o indivíduo e o grupo. Por conseguinte, as perspectivas de surgimento de uma cultura democrática participativa autêntica, válida no plano macrossociológico e não apenas nos níveis microssociológicos, passam a depender das formas de regulação que sejam capazes de dissolver as tensóes diversas - entre propósitos individuais e coletivos, entre interesse e desprendimento, entre liberdade e obrigação.

A cultura democrática participativa, plural e pública - criada pela vivência coletiva do dom e do simbolismo em espaços de poder nos quais os interesses grupais, individuais e setoriais, são transformados em favor de uma nova prática de bem comum -, deve responder à questão que já se colocava Schopenhauer no século XIX. Tal questão era a de saber sob que condiçôes o bem-estar ou o mal-estar do outro move minha própria vontade, como se fosse meu próprio bem. E ele respondia que isto somente ocorre por meio de que o outro se 
torne, de tal modo, o fim último de minha vontade, como eu próprio o sou, que eu queira imediatamente seu bem-estar e náo queira seu mal-estar, tão diretamente como se fosse o meu. "Isto, porém, pressupóe necessariamente que eu sofra com seu mal-estar, sinta seu mal como se fora o meu e, por isso, queira seu bem como se fora o meu próprio. Isto, porém, exige que eu me identifique com ele, que aquela diferença total entre mim e o outro, sobre a qual repousa justamente meu egoísmo, seja suprimida pelo menos num certo grau." (Schopenhauer, 2001: 135-136).

Ou seja, este tipo de bem moral e simbólico, na perspectiva da cultura democrática fundada na aliança, não é o resultado dos interesses materiais e privados egoístas. Diferentemente, o bem público, na perspectiva de uma cultura democrática participativa fundada no dom, deve constituir um novo código de referências normativas e axiológicas não redutível aos interesses privados ${ }^{10}$, um código que supera o egoísmo individual para instaurar uma experiência de identificação com o outro, que Schopenhauer (2001: 136) sintetiza pela expressão compaixão.

As experiências atuais de democracia participativa - como são os casos dos conselhos municipais - apontam teoricamente para este salto na instituição democrática, embora, na prática, ainda tenham um longo caminho a percorrer antes de aparecer como uma realidade efetiva. Neste sentido, é conveniente para a expansão da democracia participativa que a ação pública leve em conta o valor do simbólico para a materialização da prática associativa e solidária. Certos símbolos, como a bola e o time de futebol, as cartas de baralho ou o jogo de dominó, que aparentemente são figuras banais e de pouco interesse para a política e para a ação pública, carregam em si forte componente associativo. Infelizmente, tais figuras são, em geral, menosprezadas pelos planejadores e gestores públicos que pensam - o que é uma visão limitada da política - que a conscientização do espírito de cidadania depende apenas de estratégias de convencimento e de manipulação, desconhecendo a importância do simbolismo, em geral, para promover solidariedades e adesôes a açóes de caráter público.

Apenas uma cultura democrática apoiada no simbolismo generalizado e no "fato social total" pode explicar o aparecimento de esferas públicas híbridas que articulem as práticas primárias e as secundárias, o "mundo da vida", e os sistemas formais, como o Estado. Nessas novas esferas híbridas, as vontades e açóes particulares de cidadãos e movimentos associativos, de uma parte (lado do social), e de gestores e políticos, de outra parte (lado do institucional), devem se conjugar e se sacrificar em favor do bem comum, que apenas se define a partir da idéia de participação pública. Pensando em termos das complexas sociedades contemporâneas, podemos propor que tais esferas públicas híbridas, inspiradas na idéia de uma cultura democrática, participativa, pública e eminentemente política, fundada na circularidade de dádivas, devem ser capazes de suportar pressóes diversas e muitas vezes contraditórias. ${ }^{11}$

${ }^{10}$ Este novo tipo de cultura democrática vem sendo estimulada em experiências de inspiração associativa, como os conselhos municipais. Para alguns estudiosos dos fatos urbanos, como Orlando dos Santos Júnior, Luis César de Queiroz Ribeiro e Sérgio de Azevedo (2004: 25), tanto pela força da sua difusão no País como pelas diferenças com as experiências anteriores de participação, "os conselhos municipais representam uma importante inovaçâo institucional na gestão das políticas sociais".

11 Aqui, nos referimos às pressōes verticais, resultantes do poder institucionalizado, e pressões horizontais, derivadas dos movimentos sociais e das reivindicaçóes de base, pois "a articulação social da diferença, da perspectiva da minoria, é uma negociaçáo complexa, em andamento, que procura conferir autoridade aos hibridismos culturais que emergem em momentos de transformação histórica” (Bhabha, 2003: 21). 
Atualmente, as tentativas de criação de esferas deste porte, como os Conselhos $\mathrm{Mu}$ nicipais ou os Orçamentos Participativos, ainda têm limites claros, tanto em termos de assegurar efetiva participação (Cary, 2005), como de se constituir em instância deliberativa e não apenas consultiva. ${ }^{12}$ Todavia, constituem, sem dúvida, um bom ponto de partida para se avançar nesta via de renovação da luta democrática. Afinal, a questão não é apenas de criar novas modalidades de governo democrático, mas de reformar a governabilidade e de ampliar as bases de sustentação do jogo democrático mediante uma nova compreensão sócio-antropológica do mesmo, para que ele responda mais efetivamente às novas demandas de participação e aos novos desafios de gestão pública.

Tal esfera deve ser também suficientemente flexível para lidar com novas modalidades associativas e experiências de alianças, nascidas fora dos partidos e sindicatos tradicionais e que tomam frequentemente a forma de redes sociais (Fontes e Martins, 2006; Aguiton, 2006), de movimentos de base (Matos, 2006) e de atividades lúdicas e artísticas variadas, abrindo-se para a diversidade e a singularidade. Isto significa tanto repensar o controle social, que tradicionalmente era feito de cima para baixo, denotando o viés autoritário das políticas públicas no século passado (Rodger, 1996), como liberar novas formas de proteção social fundadas numa cultura da solidariedade, plural, diversificada e singularizada. Por um lado, esta esfera pública híbrida deve ser o lócus privilegiado para administrar as trocas de informaçôes entre Estado e Sociedade Civil e definir os critérios básicos para a redistribuição de bens, riquezas, e direitos setoriais locais ${ }^{13}$. Mas, por outro, deve também ser capaz de integrar - sem cooptar - a luta pelo reconhecimento (Honneth, 2003) que tanto motiva as mobilizaçóes sociais e culturais, com vistas à formulação de políticas mais justas. Pois "a justiça hoje", lembra por sua vez N. Fraser, "requer ao mesmo tempo a redistribuição e o reconhecimento" (Fraser, 2005: 152, tradução nossa).

\section{Conclusão}

Uma esfera pública híbrida, participativa e deliberativa, baseada na cultura do dom, deve funcionar como território simbólico para uma nova modalidade coletiva de gestáo do poder social. Ela pode e deve comportar várias dimensóes: o saber especializado e o saber comum, a ciência e a arte, o Estado e a Sociedade, a vida no trabalho e o lazer, a seriedade e a brincadeira. Deve absorver, sem se fragmentar, tensôes culturais e políticas contrárias em torno da igualdade libertária ou do que Amartia Sen designa de uma "liberdade-igual", pela qual "a crença de que uma liberdade é importante não pode estar em conflito com a visão de que é importante que os ordenamentos institucionais sejam dispostos para promover a

12 Os Conselhos de Saúde foram criados oficialmente pela Lei no 142/90, que os definiu como espaços vitais para o exercício do controle social do Sistema Único de Saúde (SUS). As atribuições legais e políticas dos Conselhos são: a) atuar na formulação de estratégias de operacionalização da política de saúde; e b) atuar no controle social da execução da política de saúde. Ao longo dos anos tais Conselhos vêm sendo estruturados em vários estados e municípios. As experiências de implantaçáo de unidades de saúde, assim como o debate nas grandes conferências de saúde, permitiram uma compreensão crescente sobre a importância da capacitação dos conselheiros como uma das medidas para aperfeiçoar este instrumento de gestão participativa, o que foi consolidado no documento Diretrizes nacionais para a capacitação dos conselheiros de saúde, publicado em 1999.

13 O Estado do bem-estar no século XX, como lembra P. Rosanvallon (1981), exerceu este papel, mas referindo-se a uma categoria de cidadania limitada ao trabalho, à cotização e à securitização, o que não é mais o caso hoje. 
igualdade de liberdades que as pessoas têm" (Sen, 2001: 53). Não há como se pensar, pois, uma cultura da dádiva capaz de suportar uma democracia participativa universalista sem que se superem as tensóes entre representação e identificação. E tal superação apenas se faz pela consideraçáo de todo o simbolismo existente nas memórias e representaçóes coletivas, informais e organizacionais.

Há, evidentemente, dificuldades teóricas inúmeras a serem resolvidas para a compreensão desta nova cultura democrática participativa fundada no dom, no simbolismo e na associaçáo. O fundamental é entender que a cultura do dom náo resulta de meras estratégias ou tentativas calculadas de se controlar a açáo de outrem, mas justamente do contrário: da superação das barreiras entre eu, mim e o outro, tema que foi teorizado de modo exemplar por George Mead (1967). Esta superação é a condição para que o dom apareça como política de reconhecimento cultural e associativa, num mundo aberto em permanência à novas formulaçóes simbólicas que produzem tensóes na totalidade social a partir das redes associativas diferenciadas e plurais e da individualizaçáo incessante.

Tal observação é particularmente pertinente em sociedades como aquelas do Sul, em que a precariedade do trabalho assalariado não deve ser traduzida como um impasse histórico que condenaria tais sociedades ao "subdesenvolvimento". Ao contrário, pelo entendimento da sociedade como fato social total, podemos verificar existir uma diversidade de estruturas simbólicas à disposição para se pensar a autonomia sócio-histórica. Mas o modo como os simbolismos são traduzidos e apropriados por diferentes sociedades depende, basicamente, do fazer político, da capacidade de se organizar novas formas associativas, e de se fundar uma cultura do dom e da associação que se enraíze nos saberes, nos desejos e nos sonhos dos cidadãos. Pensando de forma abstrata tal desafio parece uma utopia, mas, ao nos debruçarmos sobre as condiçôes concretas de produção da cultura, da sociedade e da política, podemos constatar haver experiências em desenvolvimento que são muito originais e promissoras. Sobre elas podemos começar realisticamente a pensar os fundamentos da cultura democrática participativa e associativa de valor universal, cujos fundamentos procuramos delinear no presente trabalho.

Pensamos, enfim, que o trabalho de mapeamento de tais experiências assim como os esforços de articulação e de divulgação das mesmas, nos moldes como vem sendo realizado, por exemplo, por Boaventura de Sousa Santos, é decisiva para se organizar novos espaços de solidariedade e de participação no plano transnacional ao mesmo tempo em que reforça as lutas locais de ampliaçáo dos espaços de reconhecimento e de participação. 


\section{Referências Bibliográficas}

AGUITON, Christophe - «Crise et renouveau de la démocratie en période de mondialisation». In CAILLÉ, Alain (Dir.) Quelle démocratie voulons-nous ? Pièces pour un débat. Paris: La Découverte, 2006.

ARENDT, Hannah - A condição humana. Rio de Janeiro: Forense Universitária, 2003.

BHABHA, Homi - O local da cultura. Belo Horizonte: Editora da Universidade Federal de Minas Gerais, 2003.

CAILLÉ, Alain (2000) Anthropologie du don : le tiers paradigme. Paris: Desclée de Brouwer.

CAILLÉ, Alain - «Un totalitarisme démocratique ? Non, le parcellitarisme». In CAILLÉ, Alain (Dir.) Quelle démocratie voulons-nous? Pièces pour un débat. Paris: La Découverte, 2006a.

CAILLÉ, Alain - «Introduction». In CAILLÉ, Alain (Dir.) Quelle démocratie voulons-nous? Pièces pour un débat. Paris: La Découverte, 2006b.

CARY, Paul - «Qui participe à quoi?» Revue du MAUSS semestrielle: Alter-démocratie, alter-économie. Chantiers de l'espérance, no 26, 2005, pp. 211-230.

CASSIRER, Ernst - A filosofia das formas simbólicas: II - o pensamento mítico, São Paulo: Martins Fontes, 2004.

CHANIAL, Philippe - Justice, don et association: la delicate essence de la democracie. Paris: La Découverte, 2001.

COOLEY, Charles N. - Social process. Carbondale: Southern Illinois University Press, 1966.

DAGNINO, Evelina - «Sociedade civil, participação e cidadania: de que estamos falando?». In MATO, Daniel (Coord.) Políticas de ciudadanía y sociedad civil en tiempos de globalización. Caracas: Universidad Central de Venezuela, 2004.

DEWEY, John - The public and its problem. Athens: Ohio University Press, 1997.

DUBET, François - As desigualdades multiplicadas. Ijuí: Editora Unijuí, 2003.

FONTES, Breno; MARTINS, Paulo Henrique (Orgs.) - Redes, práticas associativas e gestão pública. Recife: Editora da Universidade Federal de Pernambuco, 2006.

FRASER, Nancy - Qu'est-ce que c'est la justice sociale? Paris: La Découverte, 2005.

GODBOUT, Jacques em colaboração com CAILLÉ, Alain - L'esprit du don. Paris: La Découverte, 1992.

GODBOUT, Jacques em colaboração com CAILLÉ, A. - O espírito da dádiva, Rio de Janeiro: FGV, 1998.

GODBOUT, Jacques - «Pas de représentation sans représentativité». Revue du MAUSS semestrielle: Alter-démocratie, alter-économie. Chantiers de l'espérance, n. 26, 2005, pp. 90-104.

GODELIER, Maurice - Métamorphoses de la parenté. Paris: Fayard, 2004.

HABERMAS, Jurgen - Direito e democracia: entre facticidade e validade. Rio de Janeiro: Tempo Brasileiro, 2003.

HONNETH, Axel - Luta por reconhecimento, São Paulo: Editora 34, 2003.

JONAS, Hans (1997) Le principe responsabilité: une éthique pour la civilisation technologique, Paris: Les Editions du CERF.

LÉVI-STRAUSS, Claude - As estruturas elementares do parentesco, 3a Edição, Petrópolis: Vozes, 2003.

MATOS, Aécio - «Participação e democracia». In FONTES, Breno; MARTINS, Paulo Henrique (Orgs.) Redes, práticas associativas e gestão pública. Recife: Editora da UFPE, 2006.

MAUSS, Marcel - Sociologia e antropologia, São Paulo: Cosac \& Naify, 2003.

MOUFFE, Chantal - Le politique et ses enjeux: pour une democratie plurielle, Paris: La Découverte/MAUSS, 1994.

MEAD, George H. - Mind, self and society, Chicago: The University of Chicago Press, 1967.

MERLEAU-PONTY, Maurice - «De Mauss à Claude Lévi-Strauss». In Idem, Éloge de la philosophie, Paris: Gallimard, 1960.

NEVES, Marcelo - «Do consenso ao dissenso: o Estado democrático de direito a partir e além de Habermas» In Sousa, J. (org.) Democracia hoje: novos desafios para a teoria democrática contemporânea, Brasília: Editora da Universidade Nacional de Brasília, 2001.

RODGER, John - Family life \& social control: a sociological perspective. London: Macmillan, 1996.

ROSANVALLON, Pierre - La crise de l'Etat-providence, Paris: Seuil, 1981.

ROSANVALLON, Pierre - La nouvelle question sociale: repenser l'Etat-providence, Paris: Seuil, 1995.

SAHLINS, Marshall - Cultura e razão prática. Rio de Janeiro: Jorge Zahar, 2003.

SANTOS JÚNIOR, Orlando Alves dos; RIBEIRO, Luiz Cesar de Queiroz; AZEVEDO, Sérgio de - «Democracia e gestão local: a experiência dos conselhos municipais no Brasil». In Idem (Orgs.) Governança democrática e poder local: a experiência dos conselhos municipais no Brasil. Rio de Janeiro: Revan/ Fase, 2004.

SCHOPENHAUER, Arthur - Sobre o fundamento da moral, São Paulo: Martins Fontes, 2001.

SEN, Amartya - Desigualdade reexaminada. Rio de Janeiro: Record, 2001

TAYLOR, Charles - As fontes do self: a construção da identidade moderna, São Paulo: Ediçóes Loyola, 2005.

WALZER, Michael - Politics and passion: toward a more egalitarian liberalism, New Haven \& London: Yale University Press, 2005. 
(Página deixada propositadamente em branco) 
María Cristina Reigadas

\section{CONFIANZA Y DELIBERACIÓN: LAS CONDICIONES ÉTICAS DE LA PARTICIPACIÓN DEMOCRÁTICA}

\section{Introducción}

A más de veinte años de recuperadas las instituciones democráticas en América Latina, el debate político gira hoy en torno a las cuestiones relativas a su consolidación y calidad institucional tanto como respecto a las bases sociales de los procesos de democratización. Visiones institucionalistas y populistas o neopopulistas compiten por hegemonizar el campo interpretativo. El retorno del estado se sucede al de la sociedad civil y los sujetos de sus respectivas esferas pujan por resignificar el sentido de la crisis de la política y de lo político. Gobernantes, funcionarios, administradores y partidos políticos, por un lado, y viejos y nuevos movimientos sociales, ONG's y asociaciones voluntarias, por otro, se reflejan y acusan mutuamente: los unos, de querer robarles la función, el rol y la clientela. Los otros, de corruptos, poco transparentes e ineficaces, no sólo en la gestión, sino en su incapacidad para formular objetivos transformadores. Sin embargo, la disputa no logra soslayar la cuestión de base: los modelos tradicionales de acumulación de poder social y político, la toma de decisiones, los tipos de liderazgo, la formulación, ejecución y evaluación de las políticas públicas estatales tanto como los servicios realizados por las organizaciones comunitarias, son poco democráticos. Importan los resultados más que el modo en que éstos se construyen e importa muy poco si los sujetos "destinatarios" se transforman, aprenden y crecen en autonomía y poder decisorio.

Por otra parte, los debates sobre la construcción y calidad de la democracia en la región se dan hoy en un contexto de marcada desconfianza y desvalorización de la democracia representativa y, paradójicamente, de baja participación ciudadana.

Respecto de la primera cuestión, ${ }^{1}$ los datos son alarmantes. En Argentina (que no constituye un caso aislado en Latinoamérica) más de la mitad de la población estaría dispuesta a aceptar un régimen autoritario si se garantizara un mejoramiento económico. Mientras que un $43 \%$ respalda a la democracia, el $30 \%$ es ambivalente y el 26,5 tiene un punto de vista no democrático. A pesar de los altos niveles de afiliación política (3 millones de afiliados), hay escasa participación en actividades partidarias: sólo un 3\% participa de ellas. Solamente el $29 \%$ de los encuestados considera que hay democracia cuando se garantiza el voto y la libertad de expresión. Por otra parte, las relaciones paternalistas y clientelares no parecen

1 Véase Informe del Banco Mundial (2002). Ver también Reigadas (2004). 
haber sido superadas en la política argentina. La mayoría de los argentinos culpabilizan al Estado de su ignorancia respecto de sus deberes y se consideran niños inmaduros para vivir en democracia. Creen que los cambios deben venir desde arriba, desde el Estado pero, a la vez, lamentan la carencia de poder de éste.

En cuanto a los índices de participación ciudadana son significativamente más bajos que en Europa Occidental, Australia y Estados Unidos², siendo menor aún el índice de confianza que constituye un aspecto decisivo en la construcción de una sociedad democrática. En la Argentina solamente un 23\% confía en sus compatriotas y menos personas aún en los poderes públicos. Según una encuesta de la Universidad de Belgrano, un tercio de la población aceptaría liderazgos fuertes si la gestión produce los resultados esperados y, por los mismos motivos, otro tercio toleraría la corrupción y el clientelismo. Finalmente, la Argentina ha desarrollado una cultura de la sospecha y de la confusión, en la cual el cumplimiento de los deberes y las normas suele estar identificado con el disciplinamiento autoritario, la corrupción tolerada y el éxito es considerado como legitimador de la conducta individual y colectiva.

En síntesis, si bien se han multiplicado las acciones de la sociedad civil (movimientos sociales, organizaciones comunitarias, etc.), el índice de participación ciudadana es aún muy bajo y tiende a descender. ${ }^{3}$ Segundo, las prácticas de los distintos actores involucrados (provengan del campo social, político o gubernamental) muchas veces no son democráticas y tercero, la baja valoración de la democracia en la región sin duda tiene que ver con lo que buena parte de la ciudadanía considera sus muy escasos rendimientos. ${ }^{4}$ En suma, (1) participación ciudadana, (2) calidad de la democracia y (3) valoración de la democracia constituyen un entramado ético-político y social al que debemos interrogar a fin de salir del atolladero que pendularmente nos ha hecho creer que con la democracia sola se come o que, dado que no nos garantiza comer, bien podríamos prescindir de ella.

Sin duda que los obstáculos que operan para fortalecer y profundizar la democracia son diversos, siendo muy importante el impacto de las condiciones que impone la economía global y la política internacional y la carga histórica que al respecto pesa sobre el continente y que, por cierto, no puede ser reducida a las crisis de las últimas décadas. En cuanto a los factores culturales, se ha destacado el peso del autoritarismo, pero se han descuidado otros igualmente fundamentales, como la negación y olvido de la historia, el afán refundacionalista, la mímesis y, en el caso argentino, el excepcionalismo (Reigadas, 2000).

Por otra parte, se observa que las explicaciones económicas, políticas y/o culturales de nuestras dificultades suelen naturalizar las causas tanto como atribuirlas siempre a agentes externos. En última instancia y aún cuando cíclicamente hay autoculpación y sentimientos

${ }^{2}$ El Índice de Participación Ciudadana (2005) muestra un descenso en la participación en nuestro país en relación a ańos anteriores. Hay que relacionar el momento más alto de la participación con la crisis (y postcrisis) del 2001, tanto con la multiplicación de la solidaridad ante situaciones de urgencia y emergencia económico-social como con necesidades vinculadas a la defensa de derechos: troquistas, ahorristas defraudados, familiares de víctimas del gatillo fácil y de la seguridad.

3 Véase el Informe de Participación Ciudadana en América Latina (2005), realizado en 8 países de América Latina por la RID (Red Interamericana para la Democracia), Fundación Conciencia, GADIS (Grupo de Análisis y Desarrollo Institucional y Social) y FINES (Fundación de Investigaciones Económicas y Sociales).

4 Véase PNUD/Argentina (2004 y 2005), Encuesta “Democracia, corrupción y clientelismo” (2003), PNUD (2004). 
de impotencia, la explicación en última instancia está dada por la acción manipuladora de "los otros".

Finalmente, que América Latina tenga 150 millones de pobres y 225 millones de indigentes y sea el continente con mayores desigualdades distributivas del planeta, tal como lo certifica que el 10\% más rico tiene el 40 al $47 \%$ del ingreso y el $20 \%$ más pobre del 2 al $4 \%$, constituye un desafío singular para la consolidación de la democracia.

Mientras que algunos se cuestionan cuanta democracia puede sostenerse en tales condiciones, otros, por el contrario, consideran que hay un nexo entre pobreza y debilidad de la democracia y que su fortalecimiento constituye un factor decisivo para un desarrollo humano con justicia y equidad.

Sin embargo, las críticas y los déficits de la democracia en la región no constituyen un obstáculo para la defensa de la participación ciudadana en las cuestiones públicas, habida cuenta de que la fuerza de la democracia participativa, que combina mecanismos de la democracia representativa con otros de la democracia directa, reside en su defensa irrestricta de la soberanía popular. La participación ciudadana recentra la acción colectiva en la sociedad civil, que recupera su protagonismo y carácter público, y cuestiona en los hechos el monopolio estadocéntrico de las política.

Pero si bien hay consenso acerca de la legitimidad de la participación ciudadana, lejos se está de haberlo alcanzado cuando hay que definir qué es lo que hace democrática a la participación popular, ya que no toda participación es democrática y que más participación no asegura más democracia.

$\mathrm{Al}$ respecto, Jürgen Habermas y Amartya Sen, entre otros y por distintos caminos, han señalado que una política democrática no puede reducirse a la agregación de intereses ni a la toma de decisiones producto de la hegemonía, ni al reparto de bienes o al principio de beneficiar siempre a los desaventajados, ni tampoco fundarse en decisiones técnicas, en valores supuestamente compartidos o en la sabiduría del gobernante. Una política democrática debe asegurar la construcción de una voluntad y opinión pública racionalmente fundada. Son los debates públicos y los acuerdos racionalmente motivados que de ellos emanan lo que otorga cualidad democrática a la participación popular.

En este sentido, las teorías de la democracia deliberativa proponen un camino más complejo y más lento, pero más sólido y eficaz para promover la inclusión con igualdad y la capacidad de decidir autónomamente los propios proyectos de vida individuales y colectivos. Es por cierto su práctica habitual en distintas instituciones formales e informales lo que hace de ella, como quería Dewey, una forma de vida.

\section{Las difíciles relaciones entre ética y política}

Difícilmente pueda pensarse la política desvinculada de la ética y mucho menos si se la define a partir de la deliberación. Sin embargo, las relaciones entre ambas no son sencillas y la separación entre ambas se remonta a los inicios mismos de la modernidad. Hay que subrayar que las consecuencias de esta disociación han sido y son nefastas para el desarrollo de la vida social, máxime en situaciones de colonialismo y poscolonialismo, ya que cuando no se posee la fuerza ni el poder, la ética constituye un poderoso aliado de la liberación. Claro que no cualquier ética, y ese es el punto que es necesario discutir. En especial para unas ciencias sociales habitualmente ciegas para las cuestiones morales y en 
las cuales el estructuralismo y postestructuralismo han dificultado la comprensión de las cuestiones microsociológicas ligadas al rol del respeto y la reciprocidad, del reconocimiento y la confianza mutua, del diálogo y la conversación, en cuanto medios informales de coordinación social y fundamentos insoslayables del funcionamiento de la economía y de las instituciones políticas.

La propia mainstream de nuestras ciencias sociales y la falta de interacción entre filósofos y cientistas sociales es sin duda uno de los motivos por los cuales la ética ha sido restringida a sus aspectos estrictamente prescriptivos y considerada ajena a las duras realidades del poder. Y si bien hoy ha renacido un fuerte interés por ella, que se manifiesta en oficinas y comités de ética, empresas y foros e iniciativas gubernamentales y no gubernamentales, éste suele expresarse en discursos moralizantes y vagorosas apelación a los "valores" que confirman la desconfianza de los científicos sociales en ella. Estas recientes apelaciones a la ética más allá de las intenciones - suelen estar al servicio de complejos y oscuros intereses, y finalmente funcionan como boomerangs, que neutralizan y/o domestican su potencial crítico.

De este modo, las visiones hegemónicas de la política y de la ética ratifican su divorcio: entre la política como pura facticidad del poder y la ética como discurso abstracto no parece haber más que perversa complicidad, pero nunca un vínculo mutuamente enriquecedor y un límite para los excesos.

Sin embargo, la ética está en la raíz misma de una política democrática orientada por ideales emancipatorios y en esa medida, posee una insoslayable materialidad para la construcción de la vida social, ya que no hay cambio social imaginable sin la activa disposición de los sujetos a la autotransformación y a la cooperación.

Siguiendo a Habermas, distingo dos sentidos o aspectos de lo ético, claves para pensar la vida democrática: uno, la ética en cuanto ámbito de las actitudes, significaciones y valores encarnados en prácticas sociales y la ética en cuanto punto de vista moral universalista. $\mathrm{Al}$ primero, corresponden las cuestiones evaluativos propias de las formas de vida, ancladas siempre en contextos histórico-culturales concretos y necesariamente plurales en las sociedades complejas. Mientras que la ética es siempre necesariamente singular, el punto de vista moral nos abre a la dimensión de la universalidad en la medida en que constituye un procedimiento intersubjetivo discursivo que exige la universalización de intereses, lo cual obliga a los participantes a trascender el contexto social y particular de su propia forma de vida y adoptar la perspectiva de todos los posibles afectados. Si las cuestiones ético-evaluativas corresponden, siempre, al ámbito de los contextos histórico-culturales singulares, las cuestiones morales expresan las pretensiones universalistas de justicia. Ambos están estrechamente entrelazados tanto en las comunicaciones de la vida cotidiana como en los discursos prácticos. $\mathrm{Al}$ respecto, Habermas afirma

\footnotetext{
"Sin la irrestricta libertad individual que representa la capacidad de tomar postura frente a pretensiones de validez susceptibles de crítica, un asentimiento tácticamente obtenido no puede tener verdaderamente carácter general; sin la capacidad de cada uno de ponerse solidariamente en el lugar del otro no puede llegarse en absoluto a una solución que merezca el asentimiento general. El proceso de formación discursiva de la voluntad colectiva da cuenta de la íntirna conexión de ambos aspectos: de la autonomía de individuos incanjeables y de su inserción en formas de vida intersubjetivamente compartidas. Los iguales derechos de los individuos y el igual respeto por su dignidad personal vienen sostenidos por una red de relaciones interpersonales y de relaciones de reconocimiento recíproco" (Habermas, 1991).
} 
Es así que la participación democrática conjuga, por un lado, una ética de las relaciones interpersonales basada en el respeto, la solidaridad, el reconocimiento y la confianza y un punto de vista moral que exige someter las propias posiciones a crítica y ser capaz de modificarlas en el transcurso de un proceso de generalización de intereses. Este constituye un auténtico proceso de aprendizajes mutuos en la medida en que surge del intercambio de posiciones y perspectivas, de la adopción del punto de vista del otro y del distanciamiento respecto de los propios intereses y valores.

\section{La confianza}

El creciente interés por la cuestión de la confianza - piedra de toque del lazo social - y sobre la deliberación - piedra legitimatoria de la acción democrática -, y por el nexo entre ambas y democracia, está en relación directa con el aumento de la incertidumbre, del riesgo, de la complejidad y el pluralismo valorativo de la sociedad contemporánea y con la intensificación y multiplicación de los intercambios entre personas, bienes y mensajes producidos por los procesos de globalización, que han precarizado los lazos sociales al dislocar identidades, achicar distancias y volatilizar tiempos.

Basta mencionar dos ejemplos. Uno, la necesidad de relocalización y territorialización de las prácticas sociales, frente a los temores surgidos ante la licuación e intercambiabilidad de las experiencias y el temor a la disolución del sí mismo en un vagoroso y por momentos inasible 'global'. Sin embargo, lo local no es ya mera y solamente local, identificado con el territorio, sino una construcción compleja producto de múltiples acciones y retro-acciones que operan en diferentes tiempos y escalas espaciales.

Dos, y en relación a los sujetos de la participación democrática, el recelo respecto de los lazos impersonales y/o indirectos entre individuos, grupos y redes y, en general al 'sistema', lleva a ubicar reductivamente el lugar 'propio' de la democracia en el cara a cara de los lazos de familiaridad, vecindad y amistad. Sin embargo, la sociabilidad primaria no es el único modelo de democracia ni tampoco su seguro garante. No es el cara a cara y/o los vínculos directos y presenciales (¿cómo definir, por ejemplo, los vínculos internéticos?) lo que genera espacios democráticos, sino aquello que cumple con lo que de ella se espera: el cuidado y la acción solidaria fundados en consideraciones de justicia. Sabido es, por otra parte, que éstos vínculos no se dan "natural" o "espontáneamente" en dichos núcleos primarios y que la confianza básica indispensable para generar lazos sociales democráticos requiere una laboriosa construcción que pone en juego valores tales como decir la verdad, cumplir las promesas y trato equitativo, imparcial y neutro (Offe, 1999) que, obviamente, pueden o no hallarse en distintos tipos de instituciones, incluyendo la familia y la vecindad y la escuela.

$\mathrm{Al}$ respecto Offe sostiene que la construcción de confianza implica procesos reflexivos y abstractos, mediados por reglas institucionales que, finalmente, siempre dependen para su viabilidad de la disposición a la comprensión y al sostenimiento de los que están involucrados en ellas. En este sentido, siempre confiamos en personas, dado que cuando lo hacemos en instituciones, es a través de quiénes están encargados de cumplir los valores presentes en las reglas que rigen aquéllas. Por ello, no se trata de privilegiar un tipo de sociabilidad a otro, suponiendo, por ejemplo, que la sociabilidad primaria es más apta para la democracia. Si la democracia depende de la calidad y tipo de vínculos -y éstos residen en el ethos y la 
ética de los grupos-, éstos entonces son independientes del tipo de sociabilidad: en todo tipo de relaciones sociales se puede ser mendaz, incumplir promesas y ser parcial e injusto.

Pero el hecho de cuestionar el carácter necesariamente democrático y/o más apropiadamente democrático de la vida familiar y vecinal, no implica desconocer que estas instituciones son, en otro sentido, su cuna, ya que difícilmente pueda haber democracia en una sociedad cuyas prácticas sociales cotidianas no lo sean. Dónde la familia es autoritaria, dónde la amistad es mafiosa, donde la vecindad se convierte en un guetto al que poco le importan los demás, difícilmente crezca la democracia. Esto es a lo que Dewey apuntaba cuando sostenía que la democracia es un estilo de vida que, como tal debe cultivarse desde la temprana edad y en las instituciones primarias. No es el 'cara a cara' lo que garantiza la democracia, sino la construcción de hábitos de respeto, reconocimiento y confianza mutua. Tampoco el traslado de las prácticas democráticas de una esfera a otra (de las instituciones familiares o de las asociaciones de la sociedad civil a las instituciones políticas, por ejemplo) es automático, ni hay tampoco entre éstas una relación causal, aún cuando difícilmente haya instituciones democráticas en sociedades cuyas prácticas democráticas no lo sean.

Por otra parte y más allá de los vínculos con iguales -lazos aglutinantes, en términos de las teorías del capital social-, la democracia requiere generar vínculos con individuos y grupos diferentes y lejanos. Aprender con extraños (tal como también caracterizaba Dewey a la democracia) exige desarrollar vínculos de confianza.

Para Seligman (1997) dichos vínculos en el mundo moderno se fundan en la figura del contrato social. Este surge por un acto de confianza que obliga mutuamente al cumplimiento de promesas y une a las personas en una comunidad moral. Siguiendo a Giddens y a Luhmann (aunque en un sentido diferente), distingue confianza (trust) y confiabilidad (confiden$c e$ ) y define a ésta última en relación al conocimiento pasado y a las anticipaciones futuras; hay confidence cuando contamos con que el otro cumplirá su rol y que los sistemas abstractos funcionarán. Por cierto que es trust la que interesa para la construcción de la democracia. Esta, en razón de la incertidumbre que la habita, necesita para su funcionamiento el impulso a asumir un riesgo (confianza). En este sentido, uno confía cuando no sabe, cuando no conoce los motivos del otro, cuando se enfrenta a la 'otredad" del otro. La confianza se distingue también de la fe o creencia por cuanto surge de la interacción y es una función de reciprocidad posibilitada por los espacios que abren el juego mutuo de las expectativas de rol.

Por cierto que hay otras perspectivas sobre la confianza que, a diferencia de ésta, subrayan su dimensión instrumental. Warren (1999) advierte que si bien la democracia se funda en un acto de desconfianza hacia la autoridad, no puede prescindir de ella, dado que asegura la gobernabilidad y alivia las cargas de la decisión política. Así, confianza y democracia son modos diferentes pero complementarios de tomar decisiones y organizar acciones colectivas e instrumentos orientados a disminuir amenazas (el otro es fuente potencial de daño) y conflicto (el otro es portador de intereses antagónicos), y reducir la complejidad. Según esta interpretación, la confianza abreviaría las decisiones tornando prescindible el momento deliberativo, que por cierto requiere información, tiempo y coordinación de la cooperación social.

Hardin (1999) profundiza esta visión instrumental de la confianza y la analiza desde la teoría de la decisión racional que supone que los individuos buscan maximizar sus preferencias y economizar en el esfuerzo de ganar la información necesaria para saber que curso de acción lo logrará. Sin embargo, desde la perspectiva de la elección racional la confianza asume un carácter paradojal, ya que, por un lado, disminuye el costo de la información 
y aumenta los beneficios de la cooperación, pero, por el otro, los que confían parecerían elegir irracionalmente aumentar su vulnerabilidad.

Estas interpretaciones de la confianza parten correctamente de la naturaleza vulnerable del ser humano, máxime en los contextos de interdependencia, incertidumbre y complejidad contemporáneos, pero extraen conclusiones equivocadas al presuponer que el otro constituye, básicamente, una amenaza. Para este enfoque, la confianza es un cálculo de intereses y de reducción del riesgo antes que un proceso de comunicación social.

Otras perspectivas, como las de Foley y Diani (2001), más cercanas al contextualismo de Bourdieu y Coleman, afirman que si bien no hay duda de que la confianza es crucial para muchas relaciones sociales, tampoco hay suficiente evidencia de que confiar en general sea un índice de la salud de la democracia o de logros económicos. Para ellos, la confianza social no es el lubricante universal que aceita las ruedas de la cooperación sino el resultado de un sistema económico, político y social que funciona bien para algunos y por lo tanto, la consideración de la desigualdad en la distribución de recursos no puede estar ausente en el análisis de su construcción.

Sin duda se trata de tres posiciones diferentes que subrayan distintos aspectos o dimensiones de la confianza: en el caso de Warren y de Hardin, el papel del cálculo individual en la acción colectiva, en el de Seligman, el de los valores construidos en las prácticas intersubjetivas y, en el último, el papel determinante del contexto y las estructuras sociales. Quizás estos diferentes puntos de vista no sean necesariamente excluyentes: individuos y grupos se encuentran fuertemente enraizados en estructuras desde las cuales calculan, luchan y producen sentidos y valores. En todo caso y más allá de la perspectiva privilegiada, la confianza constituye un elemento esencial para la existencia, continuidad y "éxito" de la vida social. Lejos de ser naturalizada se construye mediante procesos reflexivos (Offe), que requieren tiempo para transformarse en hábitos. Estos hábitos de confianza, intersubjetivamente construidos y fundados en procesos comunicativos (y no solamente "hábitos del corazón" o recursos para reducir la complejidad sistémica) son los que posibilitan que la democracia funcione. Si de algo trata la confianza es, paradójicamente, acerca de cómo construir el vínculo social en ausencia de fe. Si, como sostuvo Nietzsche, somos animales que hacemos promesas, confiar y ser confiado es esencial en la construcción de la vida humana y la confianza constituye el presupuesto del lazo social y de todo proceso comunicativo.

Resumiendo: la participación democrática debe redefinirse teniendo en cuenta los contextos globalizados, complejos y plurales, y su dimensión ética, en especial aquellas disposiciones que, como la confianza, vehiculizan valores de igualdad y libertad mediante el juego de expectativas mutuas que generan. La confianza pública, lejos de ser una fácil prolongación de la confianza básica o análoga a la confianza intersubjetiva, debe ser construida reflexivamente y según reglas. En este sentido, no es un acto "irracional”, o producto de la fe, sino una disposición que vehiculiza valores de igualdad y libertad, constituyendo así la condición necesaria, aunque no suficiente de la democracia. Una vez establecido el juego del reconocimiento y confianza mutua hay que argumentar y dar razones acerca de las decisiones que atañen a las cuestiones públicas.

\section{La deliberación}

Por cierto que las prácticas deliberativas y los debates previos a la toma de decisiones en las cuestiones públicas constituye parte inalienable de la doctrina democrática. Sin embar- 
go, no sólo en la práctica y por razones de poder y de urgencias la deliberación languidece en la mayoría de las sociedades que se definen como democráticas. También la teoría ha intentado mostrar que los ajustes sistémicos, las decisiones de las élites políticas y/o tecnocráticas y las prácticas hegemónicas pueden ser sucedáneos de las prácticas deliberativas, que suelen son sospechadas de ingenuas idealizaciones dado que, obviamente, nadie ha visto ni verá a una comunidad entera (¿cuáles son sus límites??), arracimada en torno al árbol de la deliberación. Es por ello que, en una época en la que se combinan el decisionismo político y el populismo antiilustrado, es necesario revisar los fundamentos de la deliberación y seńalar sus vínculos insoslayables con la democracia. Dado que además la deliberación no puede ser erróneamente identificada con un procedimiento teórico o un saber de ilustrados, es necesario basarla en el ámbito más amplio y comprensivo de las prácticas comunicativas.

Este es el camino elegido por Habermas, quien ancla la política, por un lado, en la ética comunicativa y por otro en el ámbito jurídico-legal, aunque sin subsumirla en ellos y manteniendo así la autonomía del campo político democrático centrado en la soberanía popular discursivamente redefinida.

Los principios de la ética del discurso o ética comunicativa ${ }^{5}$, que constituyen, a su vez, los fundamentos de la política deliberativa, son el principio del discurso (D) y el principio de universalización de intereses (U). Básicamente, la democracia deliberativa sostiene que los conflictos prácticos deben dirimirse intersubjetivamente mediante argumentos basados en razones, de modo tal de tener en cuenta los intereses y perspectivas de todos los afectados presentes y futuros por la situación del caso. La generalización de intereses supone un proceso de intercambios y aprendizajes mutuos mediante los cuales se busca modificar las respectivas posiciones a fin de lograr consensos sobre cuestiones públicas racionalmente fundados. Por cierto que éstos no siempre pueden ser alcanzados y que nunca son definitivos y por ello la democracia deliberativa reconoce la legitimidad de otros principios en el campo político, por ejemplo, la negociación.

La deliberación democrática opera como un contrafáctico y presupone siempre una situación idealizada: que todos los afectados por la situación objeto de la argumentación entran a ella con igual derecho a defender sus intereses y valores libres de toda coacción y acuerdan lograr entendimientos fundados en buenas razones. Ello no es motivo - como algunos críticos pretenden - para su descalificación por "idealista" e impracticable, dado que se trata de un procedimiento que es a la vez condición de posibilidad y de legitimación de una opinión y voluntad política racionalmente fundadas y un patrón de enjuiciamiento normativo de las acciones sociales justas, pero nunca un modelo o una receta para la toma del poder. La lucha social y política corre por un andarivel y la situación ideal del discurso por otro, pero sin ésta, aquélla corre el riesgo de disolverse en la protesta, el gesto exasperado, la propuesta desarticulada, el movimiento sin institucionalización y la expresión de meras particularidades, y de carecer, además, de un procedimiento y criterio de juicio normativo para distinguir lo justo de lo injusto.

Tampoco el principio del discurso (D) debe ser confundido con un principio científico-teórico de cuño eurocéntrico. Por el contrario, se trata aquí de la capacidad comunicati-

\footnotetext{
5 Dado que la palabra 'discurso' ha sido frecuentemente mal interpretada, Habermas ha preferido referirse a su teoría como ética comunicativa, eliminando el equívoco respecto a un posible sesgo teórico e intelectualista del término discurso.
} 
va inherente a todo ser humano capaz de lenguaje y acción, de la dimensión universal de la pragmática, por medio de la cual se logran acuerdos fundados en buenas razones.

En el transcurso de la situación discursiva se construye un sistema de expectativas mutuas basadas en interpelaciones, respuestas e intercambios. Pero a diferencia de los diálogos propios de los mundos de la vida, los discursos prácticos continúan mediante procedimientos reflexivos el interjuego de reconocimiento, confianza y expectativas mutuas presentes en las conversaciones ordinarias.

Ambos principios son complementarios. Generalizar intereses no significa universalizar una particularidad ni limitarse a las opciones dadas, puesto que se trata de un proceso por el cual se producen transformaciones en el sistema existente de valores y/o intereses con la única restricción de no socavar los principios de igual respeto, igual consideración e igual trato. En este sentido, el principio de universalización es la forma en que se expresa la utopía emancipatoria en sociedades en las cuales son las razones y argumentos de los propios participantes la piedra de toque de las decisiones políticas. Ambos ofrecen una alternativa para dirimir conflictos prácticos, generar consenso y promover la construcción de esferas públicas como un ámbito de instituciones mixtas, formales e informales y de fronteras móviles y flexibles, congruentes, justas y eficaces, en contextos complejos en los cuales debe garantizarse el pluralismo valorativo y disminuir la desigualdad. ${ }^{6}$

Escuchar al otro y ponerse en su lugar, distanciarse de sí mismo para constituirse en otro para sí, modificar la propia posición, anticipar las consecuencias de las decisiones tomadas, imaginar alternativas, son algunos de las acciones discursivas que se realizan en los procesos de deliberación. Como se ve, estos procedimientos no tienen nada de 'formales', puesto que involucran debates y tomas de posición respecto a cuestiones sustantivas referidas a actitudes, intereses y valores. Pero dichas decisiones deben fundarse en buenas razones, en razones que todos podrían aceptar sin vulnerar los principios de igual respeto, trato y consideración para todos. Las razones que deben circular e intercambiarse pueden ser tanto prácticas como teóricas, jurídico-legales, como éticas, pragmáticas o estrictamente políticas.

Finalmente, ¿para qué participar? Sin duda que no hay una única respuesta. Se participa para afirmar el sentido de pertenencia y afianzar la propia identidad, para lograr mayor bienestar, para luchar por los derechos y para reclamar justicia. Para afirmarnos como sujetos autónomos y soberanos. Todos estos sentidos están vinculados y constituyen aspectos o dimensiones de la ciudadanía. Si, en términos generales, el objetivo de la participación democrática es mejorar las condiciones de vida reduciendo desigualdades, el cómo tiene que ser acorde con los mismos y debe haber concordancia entre la autonomía (o heteronomía) de medios y fines. Si el objetivo es lograr la igualdad de resultados, el cómo puede ser objeto de decisiones heteronómas. Pero si el objetivo es la potenciación de las propias capacidades para reducir las desigualdades injustas, entonces el cómo debe incluir procesos de participación que respeten tanto el principio de universalización de intereses como el principio de deliberación y argumentación: no nos transformaremos en individuos libres para reducir la desigualdad si carecemos de igual posibilidad y capacidad de tomar decisiones autónomamente.

${ }^{6}$ Tomo esta triple caracterización (contextos de complejidad, pluralismo valorativo y justicia social) de J.Bohman (1996). 
En síntesis, las políticas (públicas) definidas exclusivamente por el Estado, pensadas exclusivamente con criterios locales, orientadas a la obtención de productos y resultados y decididas mediante prácticas democráticas restringidas, carentes de consensos fundados en razones y mediante procesos deliberativos, por cierto que no contribuirán a una auténtica democracia - por más que pretendan autolegitimarse en la apelación a la participación popular. Muy especialmente, las políticas públicas que no promueven la construcción de lazos de confianza racional se verán condenadas al fracaso porque sin el humus ético de dichas virtudes todo diálogo, conversación y procedimiento deliberativo carecerá de la credibilidad necesaria para generar acciones colectivas y reforzar el lazo social.

\section{Referências Bibliográficas}

Bohman, James - Public Deliberation, Pluralism, Complexity and Democracy. Cambridge, Mass: MIT Press, 1996. Foley, Michael; Edwards, Bob; Diani, Mario - "Social Capital Reconsidered". In Idem (eds.) Beyond Tocqueville, Civil Society and the Social Capital Debate in Comparative Perspective. Hanover: TUFTS University, 2001.

Habermas, Jurgen - Escritos sobre moralidad y eticidad, Barcelona: Paidós, 1991.

Hardin, Russel - "Do we trust in government?" In Warren, Mark (ed.) Democracy \& Trust. Cambridge, Mass: Cambridge University Press, 1999.

Offe, Claus - "How can we trust our fellow citizens?, In Warren, Mark (ed.) Democracy \& Trust. Cambridge, Mass: Cambridge University Press, 1999.

Reigadas, Maria Cristina - "Modernización e identidad en América Latina. El argumento de la inferioridad", Revista de Filosofía Latinoamericana y Ciencias Sociales, Asociación de Filosofía Latinoamericana y Ciencias Sociales. Segunda Epoca, Año XXV, No 22, 2000.

Reigadas, María Cristina - "Capital social y democracia: el caso argentino", Revista de Estudos em Sociología, Vol.10, No 1/2, 2004, pp. 65-83.

Seligman, Adam - The problem of trust. Princeton, N.J: Princeton University Press, 1997.

Warren, Mark - "Introduction". In Warren, Mark (ed.) Democracy \& Trust. Cambridge: Cambridge University Press, 1999.

\section{Informes y Encuestas}

Informe sobre Capital Social del Banco Mundial para América Latina y el Caribe, 2002.

Encuesta "Democracia, corrupción y clientelismo", Universidad de Belgrano, Argentina, 2003.

Informe de Participación Ciudadana en América Latina, RID, GADIS y FINES, Buenos Aires, 2005.

PNUD/Argentina, Informe para el Desarrollo Humano, 2005.

PNUD, Democracia en América Latina, 2005. 
Sílvia Portugal

\section{Dádiva, Família e Redes Sociais}

\section{Introduçáo}

As teses sobre o processo de individualização nas sociedades modernas tendem a opôr um quadro passado de fortes laços e obrigaçóes familiares a um presente com um escasso peso das relaçôes e obrigaçôes familiares. Esta é uma visão "monocromática" da relação entre família e indivíduo (Smart e Shipman, 2004), que é preciso "colorir", repensando a natureza dos laços sociais que ligam o indivíduo à família. É este objectivo que me proponho cumprir neste capítulo. A reflexão que aqui apresento estrutura-se em torno de dois conceitos fundamentais: o conceito de dom e o conceito de rede social. Parto, assim, da discussão do estatuto da dádiva nas sociedades contemporâneas. A perenidade do sistema de dom tem sido ocultada por duas tendências hegemónicas: a das teorias utilitaristas, no pensamento académico, a do Estado, na protecção social. O sistema estatal tem um tipo específico de relação com o sistema de dom. Por um lado, muitos serviços anteriormente prestados pelas redes pessoais ou de caridade foram assumidos pelo Estado. Por outro lado, este (ao contrário do mercado) não nega o altruísmo: recebe, organiza, reparte e distribui em nome da solidariedade; solidariedade mais extensa do que a das redes primárias, mais justa do que a dos sistemas de caridade. O desenvolvimento do Estado-Providência foi, por esse motivo, visto como um substituto feliz do dom, diminuindo a injustiça e a desigualdade e repondo a dignidade dos beneficiados. Deste modo, alguns autores viram na providência estatal a forma moderna da dádiva, cujas formas tradicionais se tornariam cada vez mais residuais.

Neste texto pretendo contrariar estas perspectivas. Em primeiro lugar, defendo que sistema estatal e sistema de dádiva não são sinónimos e fundam-se em princípios diferentes. Em segundo lugar, procuro demonstrar a vitalidade do dom face às deficiências do sistema estatal. Partindo da hipótese central de que o espaço doméstico é o lugar de base do dom, o local onde ele é vivido com maior intensidade e onde é realizada a sua aprendizagem ${ }^{1}$, pretendo identificar, a partir da família, os vínculos sociais que alimentam o sistema de dádiva e analisar as lógicas que regem a sua acção.

Deste modo, o conceito de rede social surge como um conceito operacional que permite analisar, simultaneamente, a forma e o conteúdo das relaçóes sociais envolvidas na

1 Sobre as características do espaço doméstico como espaço estruturante das relaçôes sociais cf. Santos (1994 e 2000). 
produção de bem-estar. A abordagem a partir da network analysis possibilita a passagem do nível macro ao nível micro, das estruturas sociais à acção individual, ou seja, no caso, permite discutir o modo como se articulam sistemas de produção de bem-estar e condiçóes individuais.

A reflexão que aqui apresento tem por base uma pesquisa empírica, de carácter qualitativo, que estudou o papel das redes sociais das famílias no acesso aos recursos de bem-estar. Foram realizadas 60 entrevistas em profundidade a pessoas com idades entre os 25 e os 34 anos, vivendo em situação de conjugalidade, com ou sem filhos.

Qual o papel que cabe à família na produção de bem-estar? Qual o papel das redes sociais na provisão de recursos? Quais são os laços mais activos das redes? Que tipo de necessidades permitem suprir? Qual o papel dos laços de parentesco? Como se articulam as redes informais com outros modos de produção de bem-estar? O que as faz mover? Quais são as normas que regulam a sua acção? Estas foram algumas das questôes às quais a pesquisa procurou dar resposta.

O estudo reconstituiu as redes de relaçóes da família a partir de uma abordagem "egocentrada", ou seja, identificando os indivíduos que interagem com um determinado "alvo" (indivíduo ou casal) (Milardo, 1988). Este tipo de procedimento tem a vantagem de nos dar uma visão ptolomeica das redes: em vez da concepção do observador exterior obtem-se a perspectiva dos indivíduos que se encontram no seu centro. No entanto, um dos problemas das redes egocentradas consiste na dificuldade em identificar a totalidade dos membros da rede de um dado indivíduo ou família, sendo quase sempre necessário criar uma amostra do total da sua população. A pesquisa utilizou três abordagens diferenciadas para reconstituir as redes sociais: as redes de intímos ${ }^{2}$, as redes de interacção ${ }^{3}$ e as redes de troca ${ }^{4}$. Utilizando estes três procedimentos, em simultâneo, identificam-se os elementos significativos, do ponto de vista simbólico, ao mesmo tempo que se confrontam as pessoas com uma série de cenários sociais de modo a identificar os indivíduos com os quais existe interacção e trocas efectivas. Cruzam-se, assim as decisóes do/a entrevistado/a e da investigadora sobre quem deve ser incluído na rede, procurando-se, por um lado, uma aproximação à totalidade da rede social e, por outro lado, uma inclusão de diferentes tipos de laços.

Da análise realizada (Portugal, 2006) destaco algumas das conclusôes, que de seguida utilizarei para discutir a relação entre dádiva, família e redes sociais: a centralidade das redes sociais na provisão de recursos às famílias; a diferenciação dos laços activados e da morfologia das redes consoante o recurso que está em jogo; o familismo das redes sociais; a permanência e vitalidade da dádiva e a sua importância na produção de bem-estar das famílias; a complexidade do sistema de normas que regula o dom familiar.

2 As redes de intímos são constituídas pelos indivíduos considerados importantes pelo "alvo". Milardo define, operacionalmente, este tipo de redes como "indivíduos cuja opinião acerca da sua vida pessoal é importante para si" (Milardo,1988: 22).

3 As redes de interacção são constituídas pelos indivíduos com quem "ego" interage numa base de rotina.

4 As redes de troca incluem os indivíduos com os quais a probabilidade de recompensa de trocas é elevada. Este tipo de abordagem "inclui entre os membros da rede social as pessoas cujo comportamento recompensa ou penaliza ego ou as pessoas que são directamente recompensadas ou penalizadas por ego" (Fischer, 1982: 287). As trocas incluem um vasto leque de interacçóes, avaliadas quer positiva quer negativamente, que vão desde a ajuda material e a prestação de serviços, ao aconselhamento e companhia nas actividades de lazer. 


\section{Os nós e os laços}

Quem faz parte da rede? Com quem se estabelecem as trocas? Com quem se interage? Com quem se pode contar? A quem se recorre quando se precisa de emprego? A quem se deixam as crianças? A quem se pede dinheiro emprestado? A quem se contam os segredos? Para uns, as respostas a estas e outras questôes permitem identificar múltiplas relações, para outros, com diferentes perguntas obtêm-se sempre os mesmos nomes. No entanto, apesar da diversidade na morfologia das redes que foi possível encontrar, é importante sublinhar algumas características transversais que emergem na análise da identificação dos nós da rede: a primeira, prende-se com a clara distinção entre as relaçóes de parentesco e as restantes relaçôes sociais - existe a família e existem "os outros". Os laços familiares representam segurança, permanência, confiança. Por oposição, os "outros" laços estabelecidos fora do parentesco são muitas vezes alvo de desconfiança e insegurança, os relatos de desilusóes com amigos e vizinhos são muito mais frequentes do que aqueles que se referem aos parentes.

A divisão entre "a família" e "os outros" tem duas implicaçōes: por um lado, é nos laços familiares que a maioria das pessoas encontra resposta para as suas necessidades de apoio material e afectivo. Por isso, quando alguém fora das relaçóes familiares é um nó importante da rede, um amigo próximo, um colega com quem se pode contar, essa pessoa "é como se fosse da família". Por outro lado, os nós que pertencem à rede familiar tendem também a assumir a representação de um "nós" - um colectivo de pertença e de referência. Cada família dispóe de um certo número de atributos e de referências identitárias que funcionam como símbolos de reconhecimento e diferenciação social a partir dos quais se situa a identidade singular do indivíduo. O conjunto destes elementos fornece uma espécie de carta comum a todos os membros do grupo familiar cujo código é transmitido, negociado, apropriado e reapropriado, construindo ao longo do tempo a identidade familiar e definindo, a partir de uma mesma trama colectiva, a identidade pessoal de cada um. Deste modo, os laços familiares apresentam-se como um todo com identidade própria, que representa uma esfera de identificação e referência, que dificilmente se encontra para a totalidade da rede ou para outros conjuntos de relaçôes (os amigos, os colegas, os vizinhos) - "nós somos assim", "connosco nunca há problemas", "na nossa família estamos habituados a fazer desta maneira”.

A segunda característica que emerge na identificação dos nós da rede é a sua tendência para a homogeneidade social. As redes heterogéneas são menos comuns do que as homogéneas. Os elementos da rede são da mesma família, ou da mesma vizinhança, ou do mesmo grupo socioprofissional, ou têm o mesmo nível educacional. Fora da rede de parentesco, os nós da rede apresentam características socioeconómicas e socioculturais muito semelhantes. De um modo geral, as redes apresentam uma forte tendência para a homofilia (Degenne e Forsé, 1994: 43-46; Lin, 2001: 38-40), sobretudo entre as mulheres, como sublinharam Lynn Smith-Lovin e J. Miller McPherson (1993).

Longe de se construírem de uma forma socialmente aleatória, as redes de relaçóes pessoais são nitidamente marcadas pelas características estruturais de quem as compóe e, em grande parte, socialmente pré-determinadas. Se esta realidade é mais ou menos óbvia para as relaçóes de parentesco, ela continua a revelar-se nas relaçóes de afinidade. As relaçóes com amigos, colegas e vizinhos são fortemente marcadas pela homofilia, sobretudo ao nível dos estatutos socioculturais mais elevados. Se, do ponto de vista do estatuto profissional, as redes são mais heterogéneas, do ponto de vista da escolaridade os diplomas de ensino 
superior marcam a diferença: entre os licenciados a homofilia das redes de afinidade é quase absoluta .

A pesquisa que realizei permite responder afirmativamente à questão colocada por Alexis Ferrand sobre se as relaçóes familiares formam um subsistema autónomo no conjunto de relaçóes do indivíduo (Ferrand, 1992). Os parentes são os nós predominantes na maioria das redes analisadas, quer se trate de trocas, de interacção ou de significado emocional. A maioria dos laços fortes é constituída no interior das relaçóes familiares e caracteriza-se pela multiplexidade e pela transitividade. Deste modo, os parentes constituem um subsistema, fortemente interligado, no interior das redes sociais.

No entanto, se olharmos para as três relaçóes elementares fundadoras do parentesco a relação de aliança, a relação de consanguinidade e a relação de filiação (Lévi-Strauss, 1949) - verificamos que os laços gerados por cada uma delas têm funçóes diferenciadas e diferenciadoras no interior da rede. Quer de um ponto de vista material, quer emocional, os laços de filiação são com grande frequência os mais fortes, seguindo-se os laços de consanguinidade. Os nós que entram na rede por via do casamento têm, em geral, um estatuto secundário - mesmo que desempenhem um papel activo ao nível das trocas e da interacção; do ponto de vista emocional, os laços estabelecidos através da relação de aliança são secundarizados pelas pessoas entrevistadas ${ }^{6}$. Esta constatação é, no entanto, mais comum entre as mulheres do que entre os homens. As mulheres têm mais dificuldade em assumir a família do marido como sendo sua, do que o inverso.

A importância da rede de parentesco deve-se ao facto de ela oferecer "garantias" que não se encontram noutro tipo de relaçóes. Uma delas é a permanência no tempo: muitos dos laços estabelecidos fora da família - relaçóes com colegas de escola ou de trabalho, com vizinhos, com amigos - não resistem à passagem do tempo, que se sobrepóe a outro tipo de mudanças, como as geográficas. Existe um sentimento generalizado de que "com a família podemos sempre contar". Esta representação dos laços familiares resulta de um entrecruzar de vínculos biológicos, emocionais, sociais e jurídicos, socialmente construídos, simultaneamente, no interior e no exterior da família. A rede familiar representa para a maioria das pessoas entrevistadas uma rede de protecção e de segurança. Os parentes são um porto de abrigo ao qual se pode sempre recorrer - mesmo que os laços não estejam sempre activos na prestação de apoios, "eles estão sempre lá quando é preciso".

É de sublinhar que a importância dos parentes é significativa mesmo quando os laços não são positivos. As situaçôes de conflito e de ruptura das relaçôes familiares são sentidas com dor pelas pessoas que as revelam. Independentemente das causas, ser privado dos laços de parentesco representa uma perda profunda, sobretudo quando esses laços se estabelecem com base numa relação de filiaçáo ou de consanguinidade. As rupturas de relaçóes com

${ }^{5}$ Estes dados aproximam-se das conclusóes de Elísio Estanque e José Manuel Mendes sobre a permeabilidade das fronteiras de classe nas redes de amizade. Os autores concluem que a sociedade portuguesa apresenta uma "estrutura social relativamente rígida também na constituição das relaçóes de amizade, sendo as qualificaçóes a dimensão estruturadora das relações sociais de amizade” (Estanque e Mendes, 1998: 128).

${ }^{6}$ Estas conclusôes são consonantes com resultados de trabalhos anteriores. António Manuel Hespanha defende que a preferência dos laços generativos aos conjugais é uma das linhas estruturantes da família no Antigo Regime (Hespanha, 1993: 956). Brian O’Neill, ao estudar os padrōes de casamento em Trás-os-Montes, conclui que a residência natolocal não é unicamente resultado de uma falta de meios para construir casas, antes sugere uma ênfase cultural generalizada sobre a descendência e os vínculos de filiação em detrimento do casamento e dos laços de afinidade (O’Neill, 1984: 320-337). 
parentes que resultam da relação de aliança nunca são apresentadas de uma forma tão dramática, lamentam-se mais as perdas do cônjuge do que as próprias, o que vem mais uma vez confirmar a secundarização dos laços de parentesco estabelecidos através do casamento.

Na obra A corrosão do carácter, Richard Sennett (2001) analisa os novos tempos do trabalho e discute o modo como as instituiçôes modernas se sustentam em esquemas que privilegiam o curto prazo, limitando, deste modo, o fortalecimento da confiança informal. O mote é "não há longo prazo" - "um princípio que corrói a confiança, a lealdade e a entrega mútua" (Sennett, 2001: 37). O autor sublinha a desvalorização dos laços fortes e a importância dos laços fracos, num contexto de permanente mudança, onde o distanciamento e a cooperação superficial são mais benéficos do que a lealdade e o compromisso. Sennett identifica um conflito entre trabalho e família, esfera em que o compromisso mútuo e o longo prazo são fundamentais. Deste conflito, o autor extrai algumas questôes sobre a "experiência adulta": como se procuram objectivos de longo prazo numa sociedade de curto prazo? Como se podem manter relaçóes sociais duradouras? Como pode um ser humano desenvolver uma narrativa de identidade e história de vida numa sociedade composta de episódios e fragmentos? (Sennett, 2001: 41).

O meu trabalho aponta para que a resposta a estas perguntas resida nos laços de parentesco. Como atrás se observou, uma das linhas que sustenta a força dos laços familiares é a perenidade das relaçóes. O laço de parentesco oferece a perspectiva de longo prazo que falta às outras relaçôes, mais susceptíveis às mudanças de diferentes tipos e à erosão pelo tempo. É a permanência das relaçóes familiares, garantida pelo laço biológico, que permite, em larga medida, a construçáo da confiança e do compromisso mútuo que constituem âncoras instrumentais e afectivas para os indivíduos e as suas famílias. Deste modo, os laços de parentesco constituem-se como elementos estruturadores do desenho das redes sociais.

Coenen-Hunter et al. distinguem quatro tipos de laços de parentesco na sua análise das solidariedades familiares (1994: 352-361): a tendência para o desapego (détachement), o instrumentalismo, a expressividade e o familismo. O desapego caracteriza-se por um nível fraco de ajudas dadas e recebidas, a raridade dos encontros, uma distância afectiva dos parentes, uma fraca organização da rede, uma difusão restrita das solidariedades e uma confiança muito limitada no apoio prestado pelos familiares. $\mathrm{O}$ instrumentalismo caracteriza as famílias que ajudam os seus parentes em questóes concretas (guarda das crianças, trabalho doméstico). A proximidade afectiva é baixa, a frequência dos encontros decorre dos serviços prestados, a concentração geográfica da parentela é grande, não existe um sentimento de poder contar com as pessoas, nem se reconhece o dever de ter que as ajudar. A expressividade caracteriza um "género de relaçóes de parentesco menos claras" (p. 354): a proximidade afectiva é forte, existe um sentimento de poder contar com grande parte dos parentes e uma recusa de retribuição na prestação de apoio. No entanto, é possível pensar que estas características não passam de declaraçóes de boas intençóes, dado que a instrumentalidade é fraca (as ajudas dadas e recebidas são escassas). Os autores preferem, contudo, uma interpretação mais positiva: o estilo de relacionamento é muito expressivo, os sentimentos são fortes, mas não necessariamente acompanhados por possibilidades de se manifestar sob a forma de apoios concretos. Finalmente, o familismo caracteriza as famílias que gostam muito dos seus parentes e os encontram com frequência. As ajudas são intensas, sabe-se que se pode contar com os parentes e está-se disposto a ajudá-los quando é necessário. A ajuda mútua assenta em normas explícitas de solidariedade que reforçam a tendência para ajudar ligada às proximidades afectivas. 
Embora a metodologia utilizada por estes autores seja muito diferente da do meu estudo ${ }^{7}$, a tipologia e a caracterização dos laços de parentesco que apresenta parecem-me bastante pertinentes para analisar os dados da pesquisa que aqui apresento, não apenas pela suas potencialidades analíticas, mas também pela possibilidade de confrontar resultados. Analisando as propriedades dos laços de parentesco verificamos, que, em geral, esses laços são laços fortes e positivos, circula no seu interior uma grande diversidade de recursos, os contactos e trocas são intensos, existe uma interacção frequente, a influência e a interferência dos parentes, sobretudo dos ascendentes, na vida da família conjugal é significativa. As entrevistas revelam que para a maioria das famílias os laços de parentesco se definem pelo familismo, contrariando as conclusóes do estudo de Coenen-Hunter et al., no qual se afirma que o "familismo é nitidamente minoritário" (1984: 355). Ao contrário, a tendência para o desapego que preocupa os autores pela sua relevância estatística - duas famílias em cada cinco (idem: 353), é minoritária no meu estudo. Aqueles que conjugam uma baixa frequência de contactos e de ajudas com um afastamento emocional dos familiares são a excepção. Apesar dos resultados não serem comparáveis de um ponto de vista estatístico, as entrevistas permitem apontar para a existência de uma realidade social bastante distinta da descrita pelos autores para a Suíça ${ }^{8}$. A minha pesquisa mostra a importância crucial dos laços de parentesco, quer do ponto de vista instrumental, quer do ponto de vista afectivo - o parentesco é um laço determinante na configuração das redes sociais dos indivíduos e das suas famílias.

O discurso de uma das entrevistadas, expressa bem as características deste familismo, simultaneamente, instrumental e expressivo, que preenche necessidades materiais e afectivas: "Posso contar com a minha família toda... toda... o meu marido, o meu filho, os meus pais, a minha irmã, a minha sogra... são as pessoas que eu... eu sei que posso contar sempre com eles, sempre. Sei que é uma coisa incondicional. Ninguém póe condiçóes para ajudar quem gosta e eles também sabem que podem contar sempre comigo."

O familismo que caracteriza as redes sociais é alimentado por intensas relaçóes intergeracionais, uma forte matrilinearidade e uma nítida lateralização do lado da mulher. Estas três características resultam de uma complexidade de elementos: consaguinidade, afectos, apoios, sociabilidade, direitos legais, obrigaçóes morais, modos de ser, de fazer e de pensar que se constroem no tempo longo da continuidade geracional que a família garante. Até certo ponto este familismo desempenha um papel excludente face a outro tipo de relaçóes sociais, mas não apresenta as características do "familismo amoral" de que fala Edward Banfield $(1967)^{9}$. As redes sociais são marcadas pelo familismo, mas este não assume o carácter negativo que lhe confere este autor, mas, antes, um sentido positivo, desempenhando um

${ }^{7}$ A tipologia apresentada foi construída a partir de dados quantitativos recolhidos através de um inquérito por questionário e tratados estatisticamente através de uma análise de clusters (Coenen-Hunter et al., 1994: 350-352).

${ }^{8}$ Neste sentido apontam, também, outras análises relativas ao "modelo do Sul", em que se destaca o papel da família nos sistemas de protecção social de Portugal, Espanha, Itália e Grécia (Andreotti et al., 2001).

9 Edward Banfield usou o conceito "familismo amoral" para descrever as práticas dos camponeses do Sul da Itália na década de 50, caracterizando "as bases morais de uma sociedade atrasada”. Segundo o autor, estas eram explicadas pela incapacidade dos indivíduos agirem colectivamente em função de um bem comum ou de qualquer fim que transcendesse o interesse material e imediato da família nuclear. Esta incapacidade para concertar qualquer actividade para além da família imediata derivava de um ethos - o "familismo amoral" - produzido por três factores agindo em combinação: a elevada taxa de mortalidade, as condiçóes relativas à propriedade da terra e a ausência da família alargada. 
papel de recurso estratégico no plano da protecção pessoal e familiar, tal como defende Manuel Villaverde Cabral (2005).

Recentemente, este autor recuperou as ideias de Banfield para discutir o problema da "distância ao poder" da sociedade portuguesa (Cabral, 2005). Villaverde Cabral dissocia o conceito da exclusiva esfera económica e transporta-o para a dimensão social, nas suas articulaçôes com o Estado e o poder político. O autor identifica "dois grandes nexos históricos de longa duração" que se terão constituído como elos mediadores entre o "familismo amoral" e a "distância ao poder": a literacia e o despotismo administrativo do Estado português moderno. Estes dois factores constituem dois nexos estruturantes das relaçôes entre as elites do poder e as classes subordinadas, que têm contribuído para reproduzir a falta de confiança e de participação da maioria da população nas instituiçôes representativas. Articuladas entre si, estas duas formas de relacionamento comunicacional e político entre elites e massas terão gerado uma forma duradoura de dominação autoritária, de modo que, nem a liberalização do sistema político-partidário, nem a massificação do ensino, nem o crescimento económico conseguiram erradicar das representaçóes e práticas da maioria da população portuguesa um sentimento generalizado de "distância ao poder" (Cabral, 2005: 21).

Da reconstrução que o autor faz do conceito de Banfield dois traços revelam-se bastante interessantes para a presente discussão: por um lado, o "familismo amoral" é recuperado como forma de identificar um conjunto de representaçóes e práticas que favorece, no seu relacionamento externo, nomeadamente com o Estado e o mercado de trabalho, o estabelecimento de relaçóes verticais assimétricas (dependência clientelar) em detrimento de relaçóes horizontais organizadas e estáveis, nomeadamente de participação cívica, de associativismo e mobilizaçáo colectiva, em suma, os dispositivos convencionais do exercício dos direitos de cidadania. Por outro lado, Villaverde Cabral desconstrói a negatividade do conceito, sublinhando o seu carácter de recurso estratégico (de que o clientelismo faz parte integrante) no plano da protecção pessoal e familiar e no plano das relaçóes com o sistema político ${ }^{10}$.

Parto destes contributos para me interrogar sobre o carácter do familismo no nosso país. Procuro avaliar o seu impacto na configuração das relaçóes sociais e na relação entre público e privado. O familismo é uma causa para o afastamento dos indivíduos da esfera colectiva, como afirma Banfield, ou antes um mecanismo de defesa perante um Estado autoritário e deficitário em políticas sociais? Se o quisermos adjectivar, teremos, contrariando Banfield, que o designar como "familismo moral", dado que a sua acção é pautada por normas de obrigação e reciprocidade, como se verá de seguida.

\section{As normas ${ }^{11}$}

Por que é que uma pessoa ajuda a outra? Por que é que uma pessoa recebe ajudas de outra? Que expectativas têm dadores e receptores? Que normas regulam as trocas no interior das redes? O que é considerado certo e errado, justo e injusto? Como se definem as obrigaçóes? Laços diferentes obedecem a princípios diferentes?

10 Os trabalhos de Fernando Ruivo sobre as relaçóes entre poder central e local têm mostrado com clareza o modo como as relaçôes informais são um recurso fundamental no sistema político português (Ruivo, 2000).

11 Retomo, neste ponto, argumentos aprofundados em Portugal (2007). 
A pesquisa aponta para uma resposta afirmativa a esta última questáo, condicionando, assim, em grande parte, as respostas às restantes questóes. As normas que regulam a interacção no interior das redes dependem do tipo de laço que está em jogo. O que está certo ou errado, o que é devido ou não, o que é justo ou injusto depende da natureza da relação em causa. As normas reflectem uma relação entre as pessoas mais do que um equilíbrio entre coisas trocadas. Como concluem Kellerhals et al. (1995), o sentimento de justiça traduz, em primeiro lugar um projecto relacional, um "reconhecimento das pessoas".

Os trabalhos de Jean Kellerhals e dos seus colaboradores sobre os critérios que regulam a justiça distributiva (quem tem direito a quê?) e processual (como chegar a decisôes justas?) têm feito escola. No seu livro Figures de l'équité. La construction des normes de justice dans les groupes (Kellerhals et al.,1988), os autores identificam cinco questóes genéricas que estruturam a definição de justiça nos grupos: uma primeira decisão diz respeito à norma de repartiçâo: que regra utilizar para distribuir os bens raros? A necessidade, o mérito, a igualdade ou ainda outro critério? Mas colocar este princípio em acção implica a intervenção de normas de avaliação, ou seja, de critérios que permitam definir o valor das contribuiçóes e a situação dos membros do grupo que participam na troca. Em terceiro lugar, a norma de comparação define a forma como o estatuto e a identidade social são importantes para a decisão interna de justiça: estas categorias são ignoradas ou, pelo contrário, tão importantes que as normas de repartição e avaliação funcionam em função delas? Qualquer destas opçóes pode ser afectada pela natureza do bem em jogo. Trata-se de aplicar uma regra de transformação: pode-se ou não utilizar as mesmas regras e os mesmos critérios para distribuir bens de natureza diferente?

Finalmente, os autores sublinham que estes quatro aspectos da decisão de justiça estão condicionados pelo problema da norma de apropriaçáo. Trata-se de saber como o grupo constitui a massa de bens sobre os quais posteriormente procede a uma repartição. A norma de apropriação define se os títulos de propriedade individual que prevalecem fora do grupo são conservados no seu interior ou se, pelo contrário, o grupo define a todo o momento os direitos de propriedade dos seus membros. No primeiro caso, o indivíduo define as fronteiras do grupo, no segundo caso é o inverso que acontece.

A pesquisa permite concluir que a aplicação destes critérios, ao conjunto da rede, depende da natureza e da força dos laços e também do recurso em jogo. Ou seja, as normas de comparação (qual é o laço da rede) e de transformação (qual é o bem em causa) prevalecem sobre a norma de repartição. Por um lado, os critérios que definem a justiça entre contribuiçôes e retribuiçóes aplicam-se de forma diferente, dentro e fora da rede de parentesco. Como afirma Alexis Ferrand, "a grandeza, por vezes, o horror, dos laços familiares está na capacidade de decretar a equivalência de valor entre ajudas totalmente heterógeneas" (Ferrand, 1992: 89). Por outro lado, o tipo de bem em jogo obriga a rever a aplicação das normas. Bens de natureza diferente obrigam a critérios diferentes, dentro e fora da família. Se os pais têm mais do que um filho e fazem uma doação de dinheiro a um, a norma que prevalece é a da igualdade - todos devem receber o mesmo. No entanto, se os avós tiverem mais do que um neto e tomarem conta apenas do que vive mais próximo, o critério aceite é o da conjugação da necessidade com a proximidade.

Estas conclusóes são semelhantes às de Jacques Godbout na sua reflexão sobre a aplicação das normas de justiça às relaçóes de parentesco (Godbout, 1995). O autor analisa três circuitos de troca distintos - a ajuda em serviços, os presentes e a hospitalidade - e conclui que os critérios que regulam cada um deles são distintos. Godbout chega a uma conclusão 
final, para a qual também aponto: a norma da justiça é de difícil aplicação no interior da rede de parentesco. Ela apenas constitui um princípio dominante quando aplicada à comparação entre diferentes retribuiçôes para uma mesma contribuição. Ou seja, o princípio náo se aplica entre um dador e um receptor, mas entre dadores ou entre receptores. Como afirma Godbout, nas redes de parentesco a ideia de justiça náo diz directamente respeito à relação contribuição-retribuição, mas à comparação entre "pares" (dadores ou receptores) na sua relação com um terceiro (1995: 361).

A análise das normas no interior das redes mostra que estas obedecem aos princípios gerais do sistema de dádiva. A minha pesquisa demonstra a permanência e vitalidade do dom e a sua importância na produção de bem-estar das famílias, contrariando a ideia generalizada de que a dádiva desapareceu das sociedades contemporâneas e cedeu o seu lugar ao cálculo racional e à troca mercantil.

$\mathrm{O}$ pensamento dominante defende que à medida que o individualismo ganha peso, a generosidade se perde e é substituída pelo cálculo egoísta. Se, por um lado, se lamenta estas tendências, por outro, valoriza-se algumas das conquistas: o Estado-Providência apresenta-se como um substituto feliz da dádiva: ninguém se lamenta que a esmola e a caridade sejam substituídas por um sistema mais justo de segurança social. Se as sociedades contemporâneas resistem a acreditar na existência do dom é porque o representam como a imagem contrária do interesse material e egoísta: a "verdadeira" dádiva é gratuita; como a gratuitidade é impossível, a verdadeira dádiva é impossível.

Marcel Mauss, em Ensaio sobre a Dádiva (1988), afirmou a centralidade da dádiva nas sociedades arcaicas. No entanto, teve dificuldade em reconhecer que a sua existência nas sociedades modernas fosse além do estatuto de manifestação residual do passado. Penso, no entanto, tal como os autores do M.A.U.S.S. ${ }^{12}$, que "o dom é tẫo moderno e contemporâneo como característico das sociedades arcaicas” (Godbout, 1992: 20). Fenómenos como a oferta de prendas, a prestação de cuidados às crianças, aos idosos e aos doentes, os convites para festas e a hospitalidade, o voluntariado, a doação de sangue e de orgãos constituem formas de troca social que não são hoje residuais nem quantitativamente (dada a sua frequência no quotidiano) nem qualitativamente (dada a sua importância na vida dos indivíduos). Adopto a definição de dádiva proposta por Godbout em L' Esprit du don (1992), e que Caillé retoma (2000): "toda a prestação de bem ou serviço efectuada sem garantia de retorno, com vista a criar, alimentar ou recriar o vínculo social entre as pessoas"

12 O movimento M.A.U.S.S. - Moviment Anti-Utilitariste en Sciences Sociales - fundado em 1981, tem, como explica Alain Caillé, na sua apresentação ao público brasileiro, "um sentido negativo e outro positivo". O sentido negativo prende-se com a recusa do utilitarismo, a ideologia hegemónica da modernidade. O sentido positivo procura a reflexâo, a partir das ideias de Marcel Mauss sobre o dom (Caillé, 2003:16). O Movimento, que surgiu como reacção à hegemonia do economicismo nas ciências sociais que se instalara durante a década de 70, publica actualmente a Revue du MAUSS e reune uma série de investigadores de áreas diversas. Os autores do M.A.U.S.S. rejeitaram os raciocínios dominantes, recusando-se a aceitar o homo economicus como concepção do indivíduo e o mercado como princípio estruturador da sociedade. Deste modo, procuraram argumentos que lhes permitissem construir uma visão alternativa do mundo. Esses argumentos foram-lhes dados pela obra de Marcel Mauss, sobretudo pelas ideias contidas no Ensaio sobre a Dádiva. Esta obra contém a "descoberta” (a designação é de Caillé) crucial para o movimento: a de uma certa universalidade, nas sociedades arcaicas, da tríplice obrigação de dar, receber e retribuir. O dom apresenta-se, para Mauss, como um "fenómeno social total". Mesmo efectuada por indivíduos singulares, a dádiva diz respeito ao conjunto das dimensóes da acção e repercute-se em toda a sociedade. Para além da sua dimensão utilitária, ela é, essencialmente, simbólica. Não só os dons são símbolos, como os símbolos devem ser entendidos como dons. Deste modo, "o paradigma do dom pode ser compreendido igualmente como um paradigma do simbolismo” (Caillé, 2000: 125). 
(Caillé, 2000: 124; Godbout, 1992: 32). O trabalho que tenho vindo a realizar mostra como o dom, assim caracterizado, como modo de circulação dos bens ao serviço do laço social, constitui um elemento essencial da sociedade.

A perenidade da dádiva não resulta apenas da necessidade de trazer um "suplemento de alma" aos interesses mercantis e estatais, mas testemunha o "facto de o dom, ele próprio, tal como o mercado e o Estado, formar um sistema" (Godbout, 1992: 21), sistema de relaçóes sociais, propriamente ditas, enquanto relaçôes não redutíveis a interesses económicos ou de poder.

O facto de o dom ser diferente da troca mercantil não implica que seja gratuito. É verdade que "o dom gratuito não existe" (Bourdieu, 1997: 124), o dom serve para estabelecer relaçôes; uma relação sem esperança de retorno, uma relação de sentido único, não é uma relação. Mas o dom também não se reduz à expectativa de retribuição, tal como a corrente utilitarista defende: "os móbiles do dom estão relacionados entre si de uma maneira profundamente paradoxal” (Caillé, 2000: 10). Interesse e desinteresse, liberdade e obrigação alimentam a dádiva e o vínculo social que ela estabelece. Se a regra fundamental é a reciprocidade, ela não se processa numa lógica binária de dádiva e retribuição. Ao aceitar uma dádiva - "muito obrigado" - o receptor passa a ter obrigaçóes para com o dador. O dom instala entre os parceiros um estado de dívida que se torna permanente à medida que se constrói um ciclo de dom e contra-dom. Ao contrário do mercado que se rege pela anulação da dívida, a dádiva funda-se sobre ela (Godbout, 2000).

O conceito de dívida positiva utilizado por Godbout (2000) revela-se mais produtivo para analisar a circulação da dádiva no interior da família do que o de reciprocidade. Numa relação, o estado de dívida positiva escapa à equivalência e faz com que cada um considere que recebe mais do que dá, embora esteja sempre disposto a retribuir. A definição de Godbout é bastante frutífera para perceber o dom familiar, e, sobretudo, os fluxos intergeracionais: "a dívida positiva existe quando o receptor não percebe no dador a intenção de o endividar através do seu gesto - o que está estreitamente ligado ao prazer de estar em dívida, elemento essencial do estado de dívida positiva" (Godbout, 2000: 47). Esta condição marca o discurso da maior parte das pessoas entrevistadas - dívida é a palavra mais usada para se falar das dádivas dos progenitores. Por um lado, eles deram a própria vida, e essa é por si uma dádiva impossível de retribuir - embora os netos sejam por vezes encarados pelos filhos como uma recompensa dada aos pais pelos seus sacríficios. ${ }^{13}$ Por outro lado, existe a noção de que é necessário retribuir de algum modo, mas que qualquer retribuição "nunca paga” o que já se recebeu. Finalmente, como já o mostraram outros estudos (Degenne e Lebeaux, 1997), existe quase um consenso sobre a inexistência de expectativas por parte dos pais dadores face a uma retribuição dos seus filhos - como diz uma entrevistada, "eles [os pais] gostam muito mais de nos ajudar a nós do que nós os ajudarmos a eles".

A dívida com os progenitores é simultaneamente uma dívida económica e uma dívida de reconhecimento. Elementos materiais, afectivos e simbólicos misturam-se num jogo complexo que, no entanto, não deixa totalmente de lado a reciprocidade. Se o parentesco mantém a reciprocidade "à distância”, como diz Godbout, ele não a exclui definitivamente, antes a reveste de formas diversas: ela é "limitada" (Godbout, 2000: 36), "diferida"

${ }^{13}$ Deste modo, a continuidade da filiação inscreve-se no circuito amplo e no tempo longo da dádiva familiar, e é, sem dúvida, uma das formas mais claras do modo como os laços de parentesco tornam equivalente o incomensurável. 
(Bawin-Legros, 2003: 169), “indirecta” (Attias-Donfut et al., 2002: 263). Na reciprocidade familiar, por um lado, dádiva e retribuição fazem circular e equivaler coisas muitos diferentes; por outro lado, entre dom e contra-dom, o tempo pode correr sem que o ciclo se quebre.

Não conta o que se troca, nem quando se troca. Nesta dádiva, o tempo conta tanto menos quanto mais se confia no outro. Mediada pela afectividade e pela confiança, a reciprocidade entre parentes realiza-se muitas vezes à "escala de uma vida" e transforma a ajuda numa espécie de "crédito a longo prazo" que não necessita de ser retribuída no imediato, nem de ser simétrica: o contra-dom pode vir muito mais tarde ou mesmo ser destinado a outra pessoa (Bawin-Legros, 2003; Déchaux, 1990; Finch,1989). Nesta concepção inscreve-se também uma ideia clara da evolução das posiçóes de receptor e de dador ao longo da vida, de pais e filhos. Na infância e juventude, os filhos são apenas receptores, na idade adulta são receptores e dadores, de uma forma assimétrica, até que os pais atingem a velhice, e nessa altura passam eles a ser os receptores. A velhice dos pais é a altura em que a norma implícita da reciprocidade é posta em prática (Bawin-Legros, 2003; Grundy, 2005; Schaber, 1995).

Os cuidados dos idosos são um exemplo de como na dádiva familiar a norma da reciprocidade se estende no tempo longo da história familiar e vai para além da troca restrita. Cuidar dos pais na velhice não é apenas uma retribuição pelas dádivas recebidas no decorrer da vida, é também uma retribuição pelas dádivas que estes fizeram aos seus próprios pais. Deste modo, o mesmo tipo de dom pode ter diferentes actores envolvidos no momento da dádiva e no momento da retribuição. Como diz um entrevistado: "eles também tomaram conta de mim, e se um dia eu quero que alguém tome conta de mim também tenho que tomar agora conta de alguém, é simples". Filhos, pais e avós fazem parte de uma cadeia intergeracional, através da qual a dádiva circula e a reciprocidade chega sempre um dia (Attias-Donfut et al., 2002).

É necessário pensar a dádiva não como uma série de actos unilaterais e descontínuos, mas como relação: "o dom não é uma coisa mas uma relação social” (Godbout, 1992: 15). A expectativa de retribuição e a retribuição estão sempre presentes; no entanto, tendem a ser ocultadas - "muito obrigado"; "não é nada". Não só se escondem as verdadeiras regras como se enunciam outras que tendem a negar a lógica existente ${ }^{14}$. Esta foi uma das observaçóes que Mauss fez para as sociedades arcaicas: onde o investigador vê interesse e obrigação, o discurso dos actores é o da voluntariedade e generosidade. A relação do dom com as regras afasta-o do paradigma holista (tal como do modelo individualista). Na realidade os elementos de um sistema de dádiva têm uma relaçáo particular com as regras. Em primeiro lugar, "as regras do dom devem ser implícitas" (Godbout, 2000: 159). Em segundo lugar, existe uma tendência generalizada para os actores negarem a obediência a um sistema de regras num gesto de dádiva. A "verdadeira” dádiva é aquela que não tem como objectivo conformar-se com uma convenção social ou uma regra, mas sim exprimir o laço com o outro.

Deste modo, a tendência é de negar a importância do próprio dom (Godbout, 2000: 159). O dever da reciprocidade não é nomeado de modo a conservar um risco no contra-dom, uma incerteza e indeterminação. O doador age deste modo para ficar o mais longe possível do compromisso contratual que tem a propriedade de obrigar o outro,

14 Bourdieu fala de "tabu da explicitação" (1997: 124). 
independentemente dos seus sentimentos. O objectivo é deixar o outro livre de retribuir ou não, de "calcular" o que deve retribuir, quando o deve fazer, etc., de modo a "obrigar mas livremente" (Godbout, 1992: 264).

Assim, uma das características fundamentais da dádiva é o seu carácter simultaneamente livre e obrigatório. Os interlocutores são simultaneamente livres e constrangidos a dar, receber e retribuir. A relação de dom estabelece-se a partir duma situação onde nada existe a não ser indivíduos separados que, enquanto tal, seguem apenas o seu próprio interesse. Quando surge uma dádiva cria-se um sentimento de obrigaçáo, o indivíduo é livre para o assumir ou para o recusar, recorrendo, por exemplo, a um contra-dom monetário que recoloca a situação no ponto de partida. Ao assumir a obrigação de retribuir estabelece-se uma relação, no interior da qual a dádiva circula como forma de alimentar e recriar o vínculo estabelecido.

A natureza do vínculo social criado pela dádiva moderna parece, pois, ser distinta da do dom arcaico. Nas sociedades contemporâneas, a dádiva cria um vínculo social de solidariedade selectiva, construída com base em princípios de afectividade e afinidade, que se encontram em permanente construção e reconstrução. Fora da rigidez relacional e espacial das sociedades arcaicas, os indivíduos possuem uma autonomia maior na escolha dos seus círculos de pertença e na definição das suas obrigaçóes práticas e morais. Deste ponto de vista, o dom moderno é muito mais livre que o dom arcaico.

A tríplice obrigação "dar, receber, retribuir" estrutura as práticas e representaçôes dos actores, mas dela decorrem diversos problemas para a acção das redes sociais (Portugal, 2007). A pesquisa empírica revela a relação entre normas e laços e a especificidade dos laços de parentesco no interior da rede. Mostra, também, a complexidade de que se reveste a aplicação das normas no interior das redes. A análise das normas exige a diferenciação do parentesco dos restantes laços, mas obriga, também, a um olhar atento sobre o modo como se constroem e aplicam os princípios reguladores da dádiva familiar.

As interacçôes e as trocas obedecem a um modelo complexo, cujos princípios são, muitas vezes, contraditórios entre si e geradores de tensóes e conflitos. A dependência dos apoios que fluem nas redes choca com o princípio basilar da autonomia; os sentimentos de dever e de obrigação conflituam com a liberdade e a afectividade; a norma da reciprocidade ilude a assimetria das trocas; o dom coexiste com o interesse utilitário; o princípio da igualdade é obscurecido pelas desigualdades sociais e sexuais que marcam as ajudas.

Este conjunto de paradoxos deve ser olhado a partir de dois eixos fundamentais de problematização: a diferenciação do parentesco dos restantes laços e o confronto entre práticas e representaçóes. $\mathrm{O}$ trabalho empírico mostra que as normas têm uma aplicação diferenciada dentro e fora dos laços de família. As redes definem formas de inclusão e de exclusão, oferecem protecção ou indiferença, a partir de critérios de confiança e de desconfiança. As entrevistas mostram que o parentesco biológico oferece aos indivíduos a segurança que os outros laços náo comportam, ao mesmo tempo que impóe deveres e obrigaçóes claras.

Deste modo, no processo de individualização da contemporaneidade, a fragilização do laço conjugal (Singly, 2001) e do laço profissional (Sennett, 2001) não vão de par com a fragilizaçáo do laço de parentesco. O papel e a normatividade das relaçôes familiares revelam-se de múltiplas formas na pesquisa que realizei, permitindo afirmar a sua vitalidade e importância na configuração das redes sociais. Se como afirma Martuccelli, "o indivíduo existe apenas na medida em que é sustentado por um conjunto de suportes" (2002: 63), a minha pesquisa mostra que os laços de parentesco são um suporte fundamental. 
A análise das normas, no interior das redes, mostra que o parentesco tem propriedades alquímicas: torna equivalente o que não o é; permite a dependência sem perder a autonomia; concilia liberdade e obrigação; transforma a dívida num elemento positivo. Esta alquimia é possível graças ao predomínio do sistema de dádiva e ao primado do laço social sobre as coisas, na definição das relaçôes entre os indivíduos.

Tudo isto não se faz, contudo, sem problemas. A definição e a aplicação das normas têm, muitas vezes, uma dimensão conflitual, mais ou menos explícita. As tensóes, no interior da família, são, frequentemente, silenciadas, ou expressas através de não-ditos, gerando mal-estar. Outras vezes, são assumidas com veemência, gerando incompatibilidades e rupturas nos relacionamentos.

Outra dimensão relevante da dádiva familiar é a forma como reproduz, de um modo muito claro, desigualdades sociais e sexuais. Por um lado, a obrigação de reciprocidade directa aumenta nas famílias pertencentes a grupos socioeconómicos mais desfavorecidos. Por outro lado, o dever de "cuidar dos seus" inscreve-se nas representaçóes de todos, mas, sobretudo, nas práticas das mulheres.

\section{Consideraçóes finais}

A análise das normas que regulam a acção das redes mostrou que existe nas famílias um enorme potencial de solidariedade que é necessário pensar para definir o seu lugar na produção de bem-estar. O "familismo moral" que identifiquei nas redes revela-se importante pela sua dimensão de recurso estratégico, mas também pelas suas potencialidades para pensar o laço social. O "familismo moral" não se fecha ao outro, pelo contrário disponibiliza para a relação, tece obrigaçôes, assenta na confiança tecida nas relaçôes interpessoais. Deste modo, coloca um desafio à discussão das relaçóes entre público e privado.

Este tipo de laços, que estrutura as redes socias, pode dar azo a relaçóes baseadas na horizontalidade ou na verticalidade. As análises, nos países do Sul da Europa, têm destacado a dimensão vertical e a assimetria, sublinhando a importância do clientelismo e do particularismo no acesso aos recursos (Mutti, 2000; Ruivo, 2000; Santos, 1994). Mas as relações baseadas na dádiva podem, também, ser geradoras de relaçóes horizontais de associação ${ }^{15}$. Nesta dicotomia reside o lugar da família na realização do laço político. O seu papel dissociativo ou associativo joga-se na sua relaçáo com outros espaços estruturais, nomeadamente na relação com o espaço da cidadania.

As análises de Boaventura Sousa Santos sobre a relação entre Estado e sociedade civil em Portugal (Santos, 1994 e 2000) identificaram uma oscilação entre um Estado protector e um Estado predador, que constrói uma sociedade civil íntima e uma sociedade civil estranha, afastando os cidadãos que não possuem relaçóes interpessoais privilegiadas no interior do sistema administrativo. Este tipo de processos conduziu à desconfiança profunda face à capacidade protectora do Estado e contribuiu, sem dúvida, para um centramento no espaço doméstico.

Deste modo, urge pensar soluçóes alternativas para um modelo cada vez mais sujeito a pressóes. Do meu ponto de vista, a perspectiva a partir das redes sociais e da dádiva pode contribuir para a construção dessas soluçóes. O pensamento a partir destes dois paradig-

15 Como mostram os trabalhos de Paulo Henrique Martins. Cf. o Capítulo 1 deste livro e Martins (2004). 
mas permite integrar diferentes níveis analíticos e de acção, possibilitando uma reinvenção do político, sobretudo a capacidade de o pensar fora dos limites do Estado. O paradigma da dádiva impóe o princípio da pluralidade de lógicas na construção da interacção social e da ambivalência estrutural das práticas sociais que se revelam na experiência concreta da definição dos laços sociais. A perspectiva a partir das redes permite integrar uma dimensão tradicional e uma dimensão progressista, conjugando particularismo e universalismo. Oferece, deste modo, um potencial que importa discutir e valorizar.

\section{Referências bibliográficas}

ANDREOTTI, Alberta et al. - "Does a Southern European Model Exist?". Journal of European Area Studies. vol. 9, $\mathrm{n}^{\circ} 1,2001$, pp. 43-62.

ATTIAS-DONFUT, Claudine; LAPIERRE, Nicole; SEGALEN, Martine (2002), Le nouvel esprit de famille, Paris, Éditions Odile Jacob.

BANFIELD, Edward C. - The Moral Basis of a Backward Society. Nova Iorque: The Free Press, 1967.

BAWIN-LEGROS, Bernadette - Le nouvel ordre sentimental. À quoi sert la famille aujourd'hui? Paris: Payot, 2003.

BOURDIEU, Pierre - Razóes Práticas. Sobre a teoria da acção. Oeiras: Celta, 1997.

CABRAL, Manuel Villaverde - "Autoritarismo de Estado e sociedade civil real em Portugal", Comunicação ao Colóquio Internacional "Acção Colectiva, Espaço Público e Cidadania", Coimbra, 6 e 7 de Janeiro de 2005. (policopiado)

CAILLÉ, Alain - "Dádiva, cidadania e democracia". In MEDEIROS, Alzira; MARTINS, Paulo Henrique (orgs.), Economia popular e solidária. Desafios teóricos e práticos. Recife: Ediçōes Bagaço, 2003, pp.16-25.

CAILLÉ, Alain - Anthropologie du don. Le tiers paradigme. Paris: Desclée de Brouwer, 2000.

COENEN-HUNTER, Josette; KELLERHALS, Jean; von ALLMEN, Malik - Les réseaux de solidarité dans la famille. Lausanne: Éditions Réalités Sociales, 1994.

DÉCHAUX, Jean-Hugues - "Des relations de parenté inédites?”. Esprit. 1990, pp. 91-101.

DEGENNE, Alain; FORSÉ, Michel - Les résaux sociaux. Paris: Armand Colin, 1994.

ESTANQUE, Elísio; MENDES, José Manuel - Classes e desigualdades sociais em Portugal. Um estudo comparativo. Porto: Afrontamento, 1998.

FERRAND, Alexis - "Les réseaux de relations personnelles". Actes du Séminaire "Du politique et du social dans l'avenir de la famille". Paris: La Documentation Française, 1992, pp. 79-90.

FINCH, Janet - Family Obligations and Social Change. Cambridge: Polity Press, 1989.

FISCHER, Claude S. - To Dwell Among Friends. Personal Networks in Town and City. Chicago and London: The University of Chicago Press, 1982.

FONTES, Breno - "Capital social e terceiro sector: sobre a estruturaçáo das redes sociais em associaçôes voluntárias". In Paulo Henrique Martins; Breno Fontes (orgs.), Redes Sociais e saúde: novas possibilidades teóricas, Recife: Editora Universitária da UFPE, 2004, pp. 49-75.

GODBOUT, Jacques T. - L’esprit du don. Paris: Éditions La Découverte, 1992.

GODBOUT, Jacques T. - "La norme de justice dans les relations de parenté". L’Année Sociologique. vol. 45, n², 1995, pp. 351-370.

GODBOUT, Jacques T. - Le don, la dette et l'identité. Paris: La Découverte, 2000.

GRUNDY, Emily - "Reciprocity in Relationships: Socio-economic and Health Influences on Intergenerational Exchanges Between Third Age Parents and their Adult Children in Great Britain". British Journal of Sociology. vol. 56, $\mathrm{n}^{\mathrm{o}} 2,2005$.

HESPANHA, António Manuel - "Carne de uma só carne: para uma compreensão dos fundamentos histórico-antropológicos da família na época moderna”. Análise Social. 123-124, 1993, pp. 951-973.

KELLERHALS, Jean; COENEN-HUTHER, Josette; MODAK, Marianne - Figures de l'équité. La construction des normes de justice dans les groupes. Paris: PUF, 1988.

KELLERHALS, Jean; MODAK, Marianne; SARDI, Massimo - "Justice, sens de la responsabilité et relations sociales". L'Année Sociologique. Vol. 45, n², 1995, pp. 317-349.

LÉVI-STRAUSS, Claude - Les structures élémentaires de la parenté. Paris: PUF, 1949.

LIN, Nan - Social Capital. A Theory of Social Structure and Action. Cambridge: Cambridge University Press, 2001. 
MARTINS, Paulo Henrique - "A dádiva e a sua importância teórica para se pensar as relaçōes entre Estado, mercado e comunidade". Comunicaçáo Apresentada ao VIII Congresso Luso-Afro-Brasileiro de Ciências Sociais, Coimbra: Setembro de 2004. (policopiado)

MARTUCCELLI, Danilo - Grammaires de l'individu. Paris: Gallimard, 2002.

MAUSS, Marcel - Ensaio sobre a dádiva. Lisboa: Ediçôes 70, 1988.

MILARDO, Robert - "Families and Social Networks: An Overview of Theory and Methodology". In Robert Milardo (ed), Families and Social Networks. Newbury Park: Sage, 1988, pp. 13-47.

MUTTI, Antonio - "Particularism and the Modernization Process in Southern Italy". International Sociology. vol. 15 (4), 2000, pp. 579-590.

O’NEILL, Brian Juan - Proprietários, lavradores e jornaleiras. Desigualdade social numa aldeia transmontana, 1870-1978. Lisboa: D. Quixote, 1984.

PORTUGAL, Sílvia - "O que faz mover as redes sociais? Uma análise das normas e dos laços". Revista Crítica de Ciências Sociais. no 79, 2007.

PORTUGAL, Sílvia - Novas Famílias, Modos Antigos. As redes sociais na produção de bem-estar. Coimbra: Faculdade de Economia da Universidade de Coimbra. Tese de Doutoramento em Sociologia, 2006.

RUIVO, Fernando - O Estado labiríntico. O poder relacional entre poderes local e central em Portugal. Porto: Afrontamento, 2000.

SANTOS, Boaventura de Sousa - Pela mão de Alice. O social e o político na pós-modernidade. Porto: Ediçóes Afrontamento, 1994

SANTOS, Boaventura de Sousa - A crítica da razâo indolente. Contra o desperdício da experiência. Porto: Ediçốes Afrontamento, 2000.

SCHABER, Gaston - "Don de temps, don d'argent, don d'espace". In Claudine Attias-Donfut (org.) Solidarités entre générations. Vieillesse, familles, État. Paris: Nathan, 1995, pp. 97-115.

SENNETT, Richard - A corrosão do carácter. Lisboa: Terramar, 2001.

SINGLY, François de - "La naissance de l'individu individualisé et ses effets sur la vie conjugale et familiale". In François de Singly (Dir.) Etre soi parmi les autres. Paris: L'Harmattan, 2001, pp. 5-14.

SMART, Carol; SHIPMAN, Beccy - "Visions in Monochrome: Families, Marriage and the Individualization Thesis". British Journal of Sociology. vol 55 (4), 2004.

SMITH-LOVIN, Lynn; MCPHERSON, J. Miller - "You Are Who You Know: A Network Approach to Gender". In Paula England (ed.), Theory on Gender-Feminism on Theory. New York: A. de Gruyter, 1993, pp. 223-251. 
(Página deixada propositadamente em branco) 
Fernando Ruivo

\section{A Face Oculta da Lua: \\ REFLEXófes SOBRE AS RELAÇÓES ENTRE O FORMAL E O INFORMAL}

O mundo formal e oficial, as suas regras e os seus jogos discursivos, bem como aquilo que se convencionou designar como a "esfera autêntica" e politicamente séria das políticas públicas ${ }^{1}$ escondeu durante muito tempo um outro segundo mundo, um mundo composto de muitas subtilezas e nuances, um mundo, por assim dizer, de enorme complexidade. A formalidade apresentava-se, deste modo, sob vestes categóricas, absolutas e normativas, procurando atribuir-se a exclusividade das regras do jogo no que dizia respeito aos variados patamares e produtos das formas de regulaçáo da vida social.

Estávamos, no entanto, perante como que uma "fachada", e o formal, essa ponta visível do iceberg, para utilizar a bem sucedida expressão de Berger e Luckman (1985), tendia, assim, a atrair a generalidade dos olhares e a concentrar as atençôes, por essa via se ocultando um outro mundo, a verdadeira base material submersa (e portanto náo imediatamente perceptível) de sustentação desse iceberg, aquilo que poderia conduzir à compreensão mais completa, intensa e idónea da complexidade dos fenómenos que se pretendem analisar.

A este segundo mundo, um mundo portanto tendencial e intencionalmente ignorado, nunca foi tradicionalmente atribuída grande importância pelo segmento "nobre" da vida social, o qual o encarava como um elemento altamente secundário (como que um fait divers), como algo portador de um estatuto de irracionalidade e cuja intromissão no curso dos acontecimentos (bem como na sua explicação) devia, na medida do possível ser, enquanto factor eminentemente subjectivo, acautelada ${ }^{2}$. Por analogia, era como que a face oculta da lua, aquela face que, apesar de sabermos existir, parece tornar-se, à primeira vista, impraticável e, até, manifestamente inútil procurar escrutinar...

${ }^{1}$ Esta "autenticidade" postulava simplesmente que bastava definir hierárquica e centralmente essas mesmas políticas para que elas fossem racional, capilar, automática e homogeneamente implementadas por um aparelho cego e obediente de funcionários administrativos, totalmente instrumentais em relação ao interesse definido pelo Estado, bem como à sua esfera pública, separados das esferas privadas e imunes a quaisquer outras formas de influência. Tudo isto mergulha, evidentemente, nos velhos mitos administrativos construídos no final do século XIX, em consonância com a construção histórica da noção do então Estado de Direito. Os percursos do final do século XX demonstraram, para o bem ou para o mal, que a realidade se apresenta de forma bem diferente. A propósito destes percursos, teóricos e históricos, cf. a contribuição de um administrativista excepcionalmente bem atento, Timsit (1986: 169 ss.).

2 O que reflectia o predomínio e o monopólio do registo e da narrativa objectivista sobre o conjunto da vida social. 
Este segundo mundo a que nos referimos tem vindo a ser denominado como o mundo do informal ${ }^{3}$. E a marginalizaçáo deste mundo informal por parte do senso comum em geral (e do político, em particular do politicamente correcto) veio a ser seguida pela esmagadora maioria, salvo honrosas excepçóes (as quais procuravam acentuar a possibilidade de diversas e diferentes racionalidades em presença ${ }^{4}$ ), das preocupaçóes clássicas (muito especialmente, em termos políticos), redutoras e igualmente "nobres" das Ciências Sociais em geral. Até um determinado momento do século passado, deste modo, o informal tendia, pois, a ser predominantemente silenciado e considerado como pouco importante ou náo estruturante para todo o processo de construção social da realidade, bem como para todos os outros múltiplos sub-processos que vão compondo essa mesma construção 5 .

Olhando para trás, no entanto, podemos constatar que alguns marcos importantes contribuíram para progressivamente irem desconstruindo este mesmo modelo ou configuração, para alterar a incidência do olhar e da narrativa e, por essa via, contribuir para afirmar a importância do universo da informalidade, bem como dos efeitos não esperados que com ela podem ser carreados. Este facto em muito veio enriquecer a consistência e a produtividade das análises posteriormente advindas. Entre esses muitos marcos, salientemos e relembremos apenas três, os quais se revestiram de grande importância para a referida alteração do olhar e, consequentemente, da narração ${ }^{6}$.

1. Em finais da década de quarenta do século passado, Philip Selznick (1949) publicava uma obra de referência para o universo anglo-saxónico. Intitulava-se "TVA and Grass Roots" e nela o autor discorria sobre o trabalho da denominada Tenessee Valley Authority nos Estados Unidos em torno da regulação do leito do rio Mississipi e da implementação de projectos integrados de desenvolvimento sócio-económico envolvendo as populaçôes dessa

${ }^{3}$ É extremamente sintomática a definição que o Dicionário Houaiss da Língua Portuguesa, um dicionário considerado de referência obrigatória (2003: 2094) nos dá deste termo: o "que náo aparece ou se recusa a aparecer sob uma forma definida". O problema, quanto a nós, é que o informal, como tentaremos demonstrar, aparece sempre e, bem pelo contrário, nunca se recusando a aparecer. Aquela definição constituirá assim uma manifestaçáo do ponto de vista oficial. Afinal, o informal predomina, em coexistência com o formal, embora sob formas não previstas, reconhecidas e pré-definidas. De registar igualmente, o que parece altamente significativo em matéria linguística (e tudo aquilo que ela revela sobre as representaçôes sociais que nela se inscrevem), que a palavra náo consta de outros dicionários (de uso mais corrente?) consultados, tendo a sua definiçáo, neles ausente, de ser elaborada em contraposição ao termo formal (esse sim sempre presente, com remissōes para o contexto da cerimónia e do ritual). A linguagem, como se percebe, pode conter também outros patamares de linguagens, estes de silêncios e ausências, os quais necessitam, igualmente de ser socialmente lidos e compreendido.

${ }^{4}$ A propósito deste tema e do fim do mito da racionalidade, única e central, do contexto Weberiano, cf., entre outros, Crozier (1971: 218 ss.), Timsit (1986: 190 ss.) e Ruivo (2000a e b).

5 Santos (1988), a propósito da regulaçấo da vida social, revê os três modelos dessa regulaçáo (os pilares da hierarquia, do mercado e da comunidade), criticando a visão exclusivista de qualquer um deles e propondo formas complexas de articulação entre eles. Relativamente a este tema, pela nossa parte (Ruivo, 2000a: 41 ss.), avançou-se com a noção de um outro pilar de regulação, o pilar reticular, constituído por redes sociais e componentes de densidade fortemente informal.

${ }^{6}$ Esta alteração do olhar é simultaneamente acompanhada por uma transição paradigmática narrativa de igual relevo: a transição da análise top-down das políticas públicas para o seu enfoque bottom-up. Sobre o assunto, cf. Ruivo (2002). 
área daquele Estado ${ }^{7}$. A partir da análise que então efectuou sobre o processo em curso, algumas das conclusôes que vem a apresentar acabam por assumir um carácter verdadeiramente demolidor para aquilo que se encontrava então ainda solidamente estabelecido: a execução hierárquica, obediente, uniforme e homogénea das políticas públicas em todos os territórios a que se destinavam. Contrariando esta postura, Selznick deduz do seu trabalho de campo que face ao modelo formal de política inicialmente proposto, a conjugaçáo localizada e informal de técnicos, políticos estaduais e locais, de elites territoriais, de grupos de pressão e burocratas, entre outros actores do naipe envolvido na execução in loco, viria a conduzir a que a política primeiramente pensada em termos formais viesse a obter vários e muito diferentes tipos de concretizaçôes e registos territoriais ${ }^{8}$.

2. Bem mais tarde, já na década de setenta, agora do lado francês, Pierre Grémion publica o seu "Le Pouvoir Périphérique: bureaucrates et notables dans le système politique français” (1976). Nesta obra aborda também a execução das políticas públicas, concluindo similarmente e de forma igualmente demolidora, ora para o espaço europeu, que aquilo que central e inicialmente tinha sido magicado e desenhado enquanto política pública só parcial ou de forma localmente adaptada se viria a concretizar'. Este facto decorria, segundo Grémion, do jogo que se operava entre funcionários territoriais e redes notabiliares territoriais no seio daquilo que ele designava como o "sistema político-administrativo local" 10 . Ora, este jogo de ping-pong, se assim o podemos designar, um jogo desenvolvido numa atmosfera altamente informal, alterava e alterava definitivamente, na sua opinião, todo o enquadramento jurídico-formal pensado para regular a realidade do sistema político local e a própria concretização local das políticas ${ }^{11}$.

3. E, um pouco mais tarde ainda, em 1980, novamente do lado anglo-saxónico, Peter Hall publica um título que ele próprio, na apresentação, considera parecer sensacionalista

7 O modelo TVA foi posteriormente, nos anos oitenta, exportado para o exterior dos EUA no quadro da cooperação para a modernização e o desenvolvimento. Em Portugal a colaboração concretizou-se, por exemplo, no projecto Merec-Regiāo Centro, envolvendo algumas Câmaras Municipais e a entáo Comissão de Coordenação da Região Centro.

8 Era, para a altura, uma novidade e uma heresia, enunciada à revelia do que se pensava na Europa de então. E que apontava já para algo que seria mais tarde afirmado noutro local, a propósito do contexto português: "a política desdobrar-se-á numa multiplicidade de tipos de execução de medidas políticas e de formas de acçáo política que ora assumirão aqui determinado cariz, ora ali tomarão outro figurino. Qual ou quais as variáveis que influenciam esta situação? Entre outras, a variável do 'aqui' e do 'ali', a variável dos diferentes locais, dos seus agentes e das suas especificidades” (Ruivo, 2000a: 15). A este propósito, $c f$. ainda, para o caso das políticas sociais (Ruivo, 2000b).

9 A esta conclusão não terá sido alheio o contacto do autor com a produção norte-americana durante uma estadia em Harvard no início da década de setenta (1971). Bem como, evidentemente, a sua participação no Centro de Sociologia das Organizaçóes francês e o impulso e direcção deste trabalho (que retoma parcialmente a tese "Pouvoir local, Pouvoir central: essai sur la fin de l'administration républicaine", apresentada na Universidade René Descartes) por parte de Michel Crozier.

10 Definido como um "poder local que se encontra no ponto de intersecção do aparelho burocrático do Estado com as instâncias de representaçóes locais" (1976: 150). "Este sistema (...) permitiria romper com 'um esquema central/vertical de interpretação do comportamento das pessoas nas estruturas administrativas' e estabelecer, na sua vez, um outro, que designa como periférico/horizontal, manifesto numa 'rede de interacçóes' entre actores" (Ruivo, 2000a: 56).

11 Passados alguns anos, Corcuff e Lafaye (1989) reafirmavam a continuada actualidade deste trabalho de Grémion. 
mas, simultaneamente constituir, na sua opinião, uma "descrição razoavelmente exacta" do que então se passava (1980: 1). A obra intitulava-se significativamente "Great Planning Disasters" e discorria sobre a incerteza, os desastres negativos ${ }^{12}$, os desastres positivos ${ }^{13} \mathrm{e}$, essencialmente, sobre aquilo que o autor designa como a "patologia dos processos de planeamento”. Isto é, a forma como as decisôes são tomadas e, depois, ou abandonadas ou continuadas face ao volume das críticas e pressóes por parte das diferentes entidades de algum modo envolvidas (1980: 3) $)^{14}$. A comunidade ou comunidades, a burocracia, os políticos de variados quadrantes, segmentos da sociedade civil, bem como a concertaçáo de todos estes actores para além do quadro formal constituem aqui o objecto da análise. O processo de implosão de tudo aquilo que dominantemente se pensava está, assim, em plena marcha e em processo de consolidação, como se pode bem entender ${ }^{15}$.

Ora, o que se passou neste processo de implosão teórica foi o assumir da coexistência de um modelo hierárquico-formal com um outro de cariz mais horizontal-informal. Um processo que é despoletado num determinado território, um território que ostenta características e especifidades que se apresentam como marcantes e onde pontuam diferentes actores. Este traço, possibilitado pelo regresso dos actores ao âmago da cena, do jogo dos actores numa margem ou zona de incerteza ${ }^{16}$, para utilizar as palavras de Bernoux (1985: 138), é, pois e deste modo, determinante para a configuração do produto final de cada política pública localizada ${ }^{17}$.

Procurar visualizar, portanto, os laços e interacçóes existentes entre as práticas informais, bem como entre estas e o próprio sistema formal revela-se, na actualidade, como uma tarefa de extrema importância para as Ciências Sociais em geral, e isto, tanto em termos teóricos como em termos empíricos ${ }^{18}$. Bem como, visibilizar tais laços, com uma especial incidência na articulação entre redes e políticas públicas. É que todas as operações de engenharia, as quais constituem a concepção da armação ou travejamento de uma política

12 Ou abandono de projectos planeados. Por exemplo, o terceiro aeroporto de Londres (começado a ser pensado em 1967, Stansted, e ainda não construído no ano de 1979), bem como as trezentas e cinquenta milhas de auto-estradas conducentes a Londres (pensadas no final da II Grande Guerra e abandonadas, com quarenta milhas executadas, em 1973) ou o túnel do Canal (Hall, 1980: 2). Repare-se que se trata de abandonos, entre outros, pensados como tal nesse período, tendo o futuro ditado outro curso aos acontecimentos...

13 "Decisóes com resultados físicos que foram implementadas apesar de muito criticismo e, até, oposição, tendo sido mais tarde considerados como um erro por muitos detentores de informação" (Hall, 1980: 2). Entre outros, o Concorde e a Ópera de Sydney.

${ }^{14}$ Estas hipóteses de trabalho são extremamente interessantes se quisermos elaborar uma analogia com o caso português da última década no que diz respeito à localização do novo aeroporto (Ota? Alcochete? Poceirão? Rio Frio?) e ao próprio traçado da rede de alta velocidade, o TGV.

15 Por esta via se desocultando um pouco, dado o papel crescente da comunicação social, a mencionada face oculta da lua.

${ }^{16}$ Esta zona de incerteza ou, se quisermos, margem de manobra, produzida pelos contingências do ambiente em que os actores se movem constitui, como se entende, uma fonte de poder, residindo esta fonte na possibilidade de instaurar processos amplos de negociação (Bernoux, 1985: 138).

${ }^{17}$ Face às concepçóes até entâo dominantes, pode fazer-se uma analogia, salvo as devidas distâncias, com o discurso de Charles Fourier no decurso do século XVIII: "c'est un monde à rebours", isto é, trata-se, visto desta forma, de um "mundo de pés para o ar" relativamente ao mundo das anteriores formas de pensar.

${ }^{18}$ Como podemos desde já antecipar, os universos correspondentes ao formal e ao informal não se encontram, de modo algum, separados, não possuem características totalmente antitéticas, nem se encontram, à partida, animados de lógicas absolutamente contrárias. Uma ilustração desta afirmação pode ser encontrada em Ruivo (2000a). 
pública por parte dos altos decisores hierárquicos, são depois necessária e posteriormente submetidas, frise-se, a uma outra generalidade de operaçôes. Podemos designar estas manobras como intervenções de reengenharia. Trata-se de operaçóes informais desenvolvidas a outra escala, muitas vezes de incidência apenas local ${ }^{19} \mathrm{e}$, claro está, altamente dependentes das características dos variados actores que as adaptam, modificam ou, até, eventualmente, curto-circuitam, a fim de as poder ou não executar...

Podíamos citar Gabriel Garcia Marquez (2002: 125) a este propósito, quando ele afirma a determinado momento que "os romances não começam como queremos mas como eles querem”20. Passe a heresia, tão só aparente, também as políticas públicas assim se comportam. Elas, as políticas, não começam material e exactamente como foram delineadas ao centro. Desenvolvem-se em contextos que não foram os inicialmente previstos, já que os diferentes territórios de execução não possuem, obviamente, carácter homogéneo. Sofrem o manuseamento e adaptaçóes de actores colocados em diferentes patamares e lógicas, desdobrando-se, muito especialmente, tal como os romances, em ritmos muito alheios aos seus remotos autores, tanto a romancistas como a planeadores ${ }^{21}$. Trata-se do jogo das personagens e dos actores mais directamente ligados ao terreno (à história que se pretende contar ou materialmente edificar) e que aí se encontram colocados.

Tudo o que atrás foi exposto aponta, portanto, para o facto de as actividades formais possuírem aspectos informais ${ }^{22}$. Ora, estes últimos, os informais, o "manobrar por detrás da cena”, necessitam de ser descodificados, desconstruídos e analisados na sua relação com o formal, a fim de que se possam cabalmente compreender a complexidade de determinados processos e produtos sociais. É que este "manobrar" constitui um ethos de informalidade em que qualquer um de nós parece participar, apesar de tal situação não ser explicitamente reportada ${ }^{23}$. Trata-se da questão da "área cinzenta" da vida social em que toda esta actividade ostenta uma densidade que pode surpreender qualquer observador mais atento. Acresce que essa mesma actividade não se apresenta como algo de meramente pontual ou ocasional, encerrando em si uma grande consistência.

A este propósito, deve, no entanto e desde logo, entender-se, como atrás foi esboçado, que o sistema informal não é uma entidade distinta e totalmente separada do sistema formal. O sistema informal deve ser visto, para utilizar a formulação de Peter Fitzpatrick

19 Embora possam contar, por razóes funcionais, com o beneplácito ou anuência oficiosa de outras escalas e patamares do sistema sócio político.

${ }^{20}$ O imponderável e complexo processo histórico de transformação de necessidades sociais, submetidas a lutas e a diferentes mecanismos antagónicos de censura, filtragem ou afirmação, em políticas públicas (ou seus correspondentes retrocessos) ilustra bem esta afirmação.

${ }^{21}$ Poderíamos aqui acrescentar, por analogia, uma continuação do raciocínio de Garcia Marquez: (os romances), as políticas públicas e as "histórias de vida" dos actores nelas envolvidos desenvolvem-se como podem. Daí que devam ser analisadas "não tanto pelos seus nomes como pelas suas vidas secretas" (Marquez, 2002: 186).

22 E vice versa, ou seja, o facto de as actividades ou produtos informais pressuporem aspectos ou contextos de formalidade. Podemos, deste modo, a este propósito, formular o seguinte enunciado: toda a formalidade comporta informalidade, bem como toda a informalidade alberga formalidade.

${ }^{23}$ E não explicitada devido à natureza altamente sensível em termos sociais (de ordem pessoal, possivelmente menos ética ou, até, de natureza alegal) das actividades que informalmente se desenvolvem para formatar o produto formal. 
(1988), não apenas como um sistema instrumental relativamente a um poder ou manifestação formal, mas como algo constituído por esse próprio poder formal no seu interior ${ }^{24}$.

Deve entender-se, deste modo, que o formal não existe, portanto, sem o informal. E compreender-se, para além do mais, que formal e informal são duas facetas complementares (mesmo que opostas ou adaptadoras) da mesma realidade, as quais contribuem de diferentes e muitas diversas maneiras para os, igualmente, muito variados produtos sociais finais.

Formalidade e informalidade serão, assim, duas faces de um mesmo processo, reflectindo a realidade sociológica do carácter multifacetado da vida social e quotidiana. Nessa medida, os processos de políticas locais formais não poderão ser inteiramente compreendidos sem se prestar a devida atenção à informalidade que eles próprios contêm e veiculam, desse modo contribuindo para modelar os seus conteúdos.

\section{Passemos então a sintetizar, em termos de conclusão.}

As políticas da informalidade podem caracterizar-se como um instrumento que providencia ao sistema formal todo um leque de actividades de que este necessita, as quais este último processa e às quais é forçado a reagir. Poderemos, assim, encontrar uma ou várias das seguintes situaçôes ${ }^{25}$ :

a) $\mathrm{O}$ informal como coadjuvante de resolução de problemas: o informal pode constituir-se como um espaço onde determinados problemas, constrangimentos e emperramentos de ordem variada, iniciados no domínio formal e oficial, podem vir a encontrar resolução. E, na realidade, o informal encontra-se apto para lidar eficientemente com este tipo de situaçôes, já que ao seu nível se podem concretizar oficiosa e sigilosamente negociaçôes e acordos de carácter menos "racional" 26 ou alegal ${ }^{27}$ que propiciem o desbloqueamento de circunstâncias de carácter mais melindroso;

b) Neste sentido, o informal pode vir a consubstancia-se como uma espécie de "ensaio por detrás do palco" (back stage) onde decorre o processo oficial: assim, ao perspectivar compromissos e estratégias adaptativas de actuação entre actores, o informal pode auxiliar o sucesso no palco (front stage) por parte do formal;

c) O informal como compromisso de válvula de segurança: ao possibilitar novas e últimas tentativas de negociaçáo, o informal constitui-se, deste modo, como o mecanismo que pode impedir uma completa e total falta de controlo das operaçóes por parte do sistema formal e oficial;

d) O informal como alimentador de eficácia no sistema de comunicação: os agentes organizacionais necessitam de informaçóes sobre o meio ambiente que procuram operacio-

\footnotetext{
${ }^{24}$ A diferença que decorre desta formulação reside no facto de, a partir daqui, podermos passar a olhar o sistema no seu todo como uma entidade que inclui uma ampla diversidade de espaços, os quais operam simultaneamente em diferentes escalas e registos, bem como integrando diferentes posiçóes interpretativas.

${ }^{25}$ Cf. a este propósito, Laguerre (1994).

${ }^{26}$ Ou impregnados de outras racionalidades existentes em campo, bem como produtos derivados de outras lógicas.

27 Nem legais, nem ilegais. Isto é, posicionados na vasta escala de cores intermédias situadas entre os extremos (o preto e o branco) que compóem toda a paleta das cores de que afinal se encontra composta a vida social.
} 
nalizar a seu favor. A comunicação carreada a partir do informal para o interior do formal, através da relaçấo com mediadores, tradutores e interlocutores privilegiados posicionados no seu exterior, permite o acesso a informação de grande utilidade, imprescindível para uma operacionalização adaptativa (devido à tradução efectuada), a qual será muito difícil de obter de outro modo;

e) A informalidade como possível patamar de resistência: apesar de, em boa parte dos casos, a informalidade aparecer com funçóes positivas e equilibrantes de coadjuvaçáo adaptadora do sistema formal, ela poderá constituir simultaneamente uma poderosa e eficaz plataforma estratégica de construção de oposição transformadora. Oposição a agentes ou líderes do sistema formal, bem como alteração de intervençôes desencadeadas por sua iniciativa.

Poderemos, pois, concluir que muito se pode compreender a partir de uma concepçáo que abarque uma cooperaçáo adaptativa entre os dois componentes do sistema, o formal e o informal. É que o sistema formal constitui um espaço que compreende muitos outros espaços onde, quer simultaneamente, quer sucessivamente, ocorrem actividades formais e informais. Estando o sistema informal incluído no espaço formal mais vasto, a informalidade encontra-se definitivamente relacionada com a topografia do sistema social formal, constituindo, pois, como que uma província desse mesmo sistema.

\section{Referências bibliográficas}

BERGER, Peter e LUCKMAN, Thomas - A Construção Social da Realidade. Petrópolis: Editora Vozes, 1985. BERNOUX, Philippe - La Sociologie des Organisations. Paris: Seuil, 1985.

CORCUFF, Philippe e LAFAYE, Claudette - "Une relecture critique du Pouvoir périphérique". Politix. 7/8, 1989. CROZIER, Michel - Le Phénomène Bureaucratique. Paris: Éditions du Seuil, 1971.

FITZPATRICK, Peter - “The Rise and Rise of Informalism”. In Matthews, Roger, Informal Justice. London: Sage, 1988.

GRÉMION, Pierre - Le Pouvoir Périphérique: bureaucrates et notables dans le système politique français. Paris: Seuil, 1976.

HALL, Peter - Great Planning Disasters. London: Weidenfeld and Nicholson, 1980.

HOUAISS, Antônio - Dicionário Houaiss de Lingua Portuguesa, Tomo IV (FRE-MER). Lisboa: Círculo de Leitores, 2003.

LAGUERRE, Michel - The Informal City. London: MacMillan Press, 1994.

MARQUEZ, Gabriel García - Viver para contá-la. Lisboa: Dom Quixote, 2002.

RUIVO, Fernando - O Estado Labirintico: O Poder Relacional entre Poderes Central e Local em Portugal. Porto: Afrontamento, 2000a.

RUIVO, Fernando - Poder Local e Exclusão Social: Dois Estudos de Caso Sobre a Organização Local de Luta Contra a Pobreza. Coimbra: Quarteto, 2000b.

RUIVO, Fernando - "Localização de Políticas Públicas". Oficina do CES. n. o 178, 2002.

SANTOS, Boaventura de Sousa - "O social e o politico na transição pós-moderna”. Oficina do CES. nº1, 1988.

SELZNICK, Philip - TVA and Grass Roots. Berkeley: University of California Press, 1949.

TIMSIT, Gérard - Théorie de l'Administration. Paris: Economica, 1986. 
(Página deixada propositadamente em branco) 
Adriana Marrero

\section{DESPUÉS DE LA DESTRUCCión DEL ESTADO Y DEL FRACASO DEL MERCADO. EL REDESCUBRIMIENTO DE LA SOCIEDAD, SU CONVERSIÓN EN “CAPITAL” Y SU PAPEL EN LA LEGITIMACIÓN DE LA DESIGUALDAD}

\section{Introducción}

Tal vez uno de los aspectos más llamativos de la teoría social actual, es el aparente re-descubrimiento de la sociabilidad. Más curioso aún, es que este "re-descubrimiento" está siendo llevado a cabo, principalmente, desde la propia Sociología. Al fin de cuentas, ¿qué es la Sociología, sino el estudio de las relaciones sociales? ¿Qué es si no el estudio de la sociabilidad? Son muchos y variados los factores que nos han traído a este ya viejo lugar de reflexión y de análisis; algunos de ellos serán examinados luego. Pero lo cierto es que un siglo y medio después de la aparición de las primeras construcciones teóricas que guiaron el desarrollo de los distintos paradigmas que han conformado a la Sociología como ciencia, nos encontramos, nuevamente, ante la circunstancia de discutir la sociabilidad y preguntarnos sobre su naturaleza y dinámica.

Variados son también los nuevos conceptos que recientemente han dado cobijo a estas nuevas interrogantes sobre la sociabilidad: el "capital social" es uno de ellos y como tal ha venido a describir las características y los efectos que tiene la sociabilidad humana y el agrupamiento de personas en su bienestar físico, anímico, y social. Pero como toda teoría, ésta también tiene su origen en intereses y en perspectivas prácticas, y no está ajena a la necesidad de pensar la realidad social e imaginar nuevas maneras de diseńo y puesta en práctica de políticas públicas destinadas a combatir la pobreza y la marginalidad, principalmente en el mundo no desarrollado.

En este artículo me propongo mostrar algunos supuestos básicos de la teoría en algunas de sus vertientes, mostrar algunos aspectos críticos, y proponer algunas hipótesis que pueden explicar su éxito en las ciencias políticas y sociológicas de los últimos lustros.

\section{El redescubrimiento y su contexto}

El auge liberalizador de los ochenta tuvo profundos y devastadores efectos en el tejido social de los países no desarrollados. Las crisis económicas de los noventa, y en el cono sur de América Latina, de principios del este siglo, pusieron en evidencia la desprotección de vastos sectores sociales que, sin el auxilio de la red de políticas sociales que habían sido 
desmanteladas con el achicamiento del estado como resultado de la aplicación de políticas liberales, cayeron rápida y masivamente por debajo de la línea de pobreza y aún, de la indigencia. Este era un panorama inédito para unos países tradicionalmente definidos como de "capas medias", desacostumbrados al hambre y a la privación. El modelo debía ser revisado. Al final de cuentas, el mercado no podía resolverlo todo, de la mejor manera. Pero por otro lado, el fracaso neoliberal no convenció a los impulsores del modelo de la necesidad de revisar su desconfianza en relación al estado. En la opinión pública, la prolongada prédica antiestatista había surtido efecto, y pocos esperaron ya que se volviera a apelar a la acción integradora del estado y de su institucionalidad para el diseño y aplicación de políticas sociales. Se generaron así las condiciones para el surgimiento de una nueva teoría que sirviera como inspiradora de políticas públicas, al solucionar un doble problema: la identificación de un nuevo factor explicativo de la crisis social y su uso como factor clave para el desarrollo. Ese concepto fue el de "capital social".

El capital social enfocó los microprocesos de solidaridad recíproca al interior de los pequeños grupos sociales, constituyéndose en una "tercera vía" entre el estado y el mercado, permitiendo la visualización de unas formas de intercambio económico que quedaban frecuentemente invisibilizadas debido, en parte, al carácter no monetario de los intercambios. El trueque, la donación, y las ayudas en formas de servicios o regalos desinteresados entre vecinos, amigos y parientes, comenzaron a ser vistos no ya sólo como una red de solidaridad apoyada en la afectividad y en el compromiso moral que sostiene a los pobres -la única en momentos de crisis extrema- sino como una forma encubierta de circulación económica que no podía quedar fuera de la "contabilidad" oficial.

Recordemos que la sociología no desconocía la existencia de esas relaciones informales y su utilidad para el sostén vital y emocional de las personas y la teorización sobre la importancia de la interdependencia recíproca en comunidades tiene una larga tradición ${ }^{1}$.

Desde que Tönnies formulara su clásica distinción entre Gemeinschaft y Gesellschaft, estos conceptos sufrirían sucesivas reinterpretaciones en los diversos esquemas teóricos, pero siempre conservando lo que constituye el núcleo duro de la polaridad: el que señala la oposición entre una lógica racional, formal e impersonal - que fundamenta la economía clásica y la organización burocrática (Gesellschaft), y la motivación afectiva, según la cual las redes y agrupaciones que forman los sujetos involucrados constituyen, para ellos, fines en sí mismos (Gemeinschaft). En términos simples, la Gemeinschaft se basa en vínculos de sangre o parentesco, de lugar o vecindad y de afecto o amistad, y se reconoce por los siguientes atributos: unidad, división del trabajo basada en la ayuda y asistencia mutua; equilibrio de las voluntades humanas en interdependencia mutua; autoridad basada en la edad y la sabiduría, un hábitat común, acción común dirigida hacia objetivos comunes que se consideran dados; relaciones de parentesco; relaciones de amistad; sentimiento recíproco y obligatorio; obligaciones difusas y generales; idioma, costumbres y creencias comunes; posesión y diversiones mutuas; espíritu de hermandad. La Gesellschaft se basa en la voluntad racional y consiste en relaciones contractual y funcionalmente específicas, establecidas conscientemente para el alcance de objetivos planteados. Está articulada en medio de la convención, la legislación y la opinión pública, y se distingue por los siguientes atributos: individualismo, acción en términos del propio interés; reglamentaciones positivas

1 Una revisión amplia y comprensiva del concepto de "redes sociales" de las distintas perspectivas teóricas relacionadas con el mismo puede encontrarse en Portugal (2007). 
y específicas; esferas de contacto delimitadas; relaciones de dinero y crédito; obligaciones limitadas; falta de relaciones familiares mutuas. Tönnies sostenía que la evolución histórica transcurría desde la Gemeinschaft a la Gesellschaft, aunque en los hechos ambos tipos pueden coexistir y encontrarse interrelacionados, en grados diversos, en distintas estructuras empíricas (Mc. Kinney, 1968: 118-119). Desde aquí es posible rastrear la tipología a través de casi toda la teoría social.

Sin embargo, también es cierto que a pesar del innegable lugar asignado a los lazos afectivos y comunitarios en toda a teoría social, la sociología moderna estuvo dominada por la supremacía de la racionalidad en todas sus formas. Al identificar las relaciones sociales familiares y corporativas a nivel micro, eminentemente particularistas, con formas premodernas, irracionales, o relativamente primitivas de estructuración social (como la tribu, el feudo, los gremios medievales o la aristocracia), la teoría termina atribuyendo a estos lazos una posición subalterna a los vínculos universalistas, formales y racionales, en los que se fundaba el orden social moderno y sus instituciones. A nivel político-práctico, los esfuerzos de construcción institucional de organizaciones modernas y racionales, tales como el Estado o la Economía - más o menos planificada, más o menos liberal - contribuyó al progresivo olvido de los efectos económicos del relacionamiento comunitario.

Esto es, en parte, lo que redescubre la teoría del Capital Social (CS). En otros lugares (Marrero, 2004, 2006), he mostrado la teoría misma y he desarrollado argumentos críticos sobre ella, tanto desde el punto de vista de su lógica teórica, como desde la consideración de sus consecuencias prácticas. No volveré sobre ello. Pero baste con señalar que las actuales formulaciones de la teoría - que son variadas y heterogéneas - pueden ser agrupadas en dos distintas vertientes.

a) Por un lado, están aquellas que ven el CS - como forma de sociabilidad - y a las transacciones que ocurren dentro de la familia, el barrio o el micro grupo, dentro de la dinámica más general de la estructuración y la reproducción sociales. El principal exponente de esta visión es, por supuesto, Pierre Bourdieu. Expresada en términos simples, esta visión del CS se basa en el supuesto de que la sociedad se reproduce y se perpetúa a sí misma, a través de los esfuerzos que desarrollan las personas de los distintos grupos por mantener y trasmitir a sus descendientes aquellos bienes sociales que son característicos de su lugar en la sociedad, lo que a nivel macro se expresa a través de la permanencia de las diferenciaciones, desigualdades, y distancias sociales que separan a unos grupos de otros.

Como en las sociedades modernas el ordenamiento social se encuentra explícitamente y jurídicamente legitimado por el principio del logro y del mérito, estos actos de transmisión de bienes y privilegios sociales deben asumir un carácter relativamente oculto, para lo cual suelen ser eufemizados o disimulados a través de mecanismos diversos, entre los cuales encuentra un lugar destacado la transformación de unas formas de capital en otras: el capital económico se transforma a través de inversiones en el cultivo de relaciones apropiadas y en una escolarización determinada, en CS y educativo, los que rendirán unos beneficios que asegurarán la permanencia y la transmisión de capital - de nuevo económico - a la siguiente generación. En esta perspectiva, el CS no es más que una forma del capital y por lo tanto no es independiente de éste. Poseen CS los poseedores de capital. En esta perspectiva crítica, por tanto, el CS es una forma más de ocultamiento de la apropiación del beneficio social por parte de unas clases en perjuicio de otras (Bourdieu).

b) Por otro lado, se encuentran aquellas teorías que ven al CS como una forma cualquiera de obtener beneficios de cualquier tipo, a través del contacto continuado en el tiempo 
con otras personas del mismo grupo social. James Coleman o Francis Fukuyama son exponentes clásicos de esta vertiente. Desde este punto de vista, el CS se aproxima al concepto de "densidad moral" de Durkheim, en el sentido de que cuanto más numerosas sean las relaciones sociales que pueda mantener una persona, más rico será en términos de CS. Las relaciones con los propios familiares, vecinos del barrio, conocidos en general, le permiten a la persona acceder a través de intercambios de favores, expectativas de reciprocidad futura y otros mecanismos semejantes, a los beneficios que resultan del acceso a la disponibilidad de otros. Desde esta perspectiva, el CS, a diferencia de las otras formas de capital, puede encontrarse en personas de cualquier clase, sea cual sea su lugar social. Los pobres o indigentes que logran satisfacer ocasionalmente sus necesidades más básicas de alimento gracias a la solidaridad de otros, contarán con CS siempre que dispongan de estos "otros" a quienes recurrir. El capital, entonces, puede estar presente a todo lo largo de la escala social. Asimismo, las relaciones aparentemente más desinteresadas, como la de una madre con su hija o hijo, las relaciones de pareja o de cualquier otro tipo, pueden ser importantes fuentes de CS. En otras versiones de este mismo abordaje, - típicamente en la de Robert Putnam - el CS asume la forma de normas institucionalizadas que dotan de previsibilidad a la acción individual: la vigencia del ordenamiento jurídico, la efectividad de la acción estatal o el respeto de las normas de tránsito, pueden acrecentar el CS de las personas que pertenecen a la comunidad donde se aplica dicho ordenamiento. Estas últimas formulaciones, despojadas del carácter crítico que la teoría de Bourdieu asignaba al concepto de "capital", son las que han venido predominando en la producción sociológica sobre el tema.

Como puede desprenderse de acá, entonces, la principal contribución de la teoría del CS consiste no en el descubrimiento de tales lazos en sí mismos para la conformación de un orden moral de reciprocidad (como ya había hecho Durkheim), ni en su importancia en términos de generación de riqueza y de eficacia histórica (como hizo Weber), sino en su revalorización como locus de reencuentro y de reconciliación de lo comunitario, familiar y privado con lo asociativo, instrumental, y público como generadores de riqueza social, a través de la simple atribución o la acentuación de un carácter económico a intercambios que tienen muchas veces - ante los ojos de sus participantes - una naturaleza distinta.

Buena parte de las objeciones a la teoría que hemos formulado en otros lugares, no tiene que ver entonces con el re-descubrimiento de la importancia de la sociabilidad, lo que es hasta cierto punto banal. De lo que se trata, es de mostrar cómo un fenómeno que es constitutivo de la dinámica de funcionamiento y conservación de las sociedades - incluso de reproducción de las desigualdades más notorias de esas sociedades - son elevados a la categoría de factores francamente positivos, y potenciadores del desarrollo de las sociedades.

\section{El éxito de la teoría}

Son varios los factores que explican que este concepto, impulsado principalmente desde los "think tanks", haya tenido una recepción tan favorable entre los diseñadores de políticas a nivel global, los gobiernos nacionales, los actores locales, las organizaciones no gubernamentales, y gran parte de la teoría social. Algunos de ellos pueden ser:

1. Se trata de un enfoque que se centra en un aspecto ya conocido de la vida social -los lazos de solidaridad basados en la confianza que proporciona la pertenencia a grupos- al 
que se atribuye un rendimiento económico. Esta teorización fue el "toque de Midas" para unas relaciones que, desde el auge de la modernidad y de la asociatividad como modelo racionalizador de las relaciones sociales, había relegado la sociabilidad cotidiana al ámbito subordinado de lo privado, lo emotivo, lo simple, lo primitivo, lo no desarrollado, lo irracional. Todo aquello que, bajo el peso simbólico de la hegemonía de las racionalidades del igualitarismo del estado benefactor o del liberalismo del intercambio mercantil era visto como marginal, como no relevante, como opaco, o incluso, como resistente, se convirtió, como por encanto, en el cuerno de oro de la abundancia social.

2. A nivel de políticas públicas, esto abre posibilidades únicas para naciones que -hundidas en la pobreza y fracturadas socialmente- descubren que el secreto de la riqueza de sus países dormitaba en el seno de aquello en lo que eran "verdaderamente" ricas: masas de personas que lo único que tenían era a sus semejantes. No es sorprendente que muchos gobiernos, imposibilitados de acudir a un aparato estatal de bienestar social desmantelado por décadas de prédica anti-intervencionista, y con un sistema de mercado debilitado por la extensión de la pobreza extrema, la desigualdad, y las sucesivas crisis del capitalismo global, vieran con buenos ojos la posibilidad de contabilizar como parte de la riqueza nacional, el valor económico de unos intercambios familiares, comunitarios, vecinales que, limitadas al ámbito de lo particular, y realizados con otros propósitos y sobre otras bases, no encontraban lugar en el ámbito de lo público. El que en esos intercambios se transaran bienes y servicios de muy distinta calidad y cantidad, no evitó que se intentara ver en todos ellos, aún en los más miserables, los que apenas permitían una subsistencia elemental, una fuente y una muestra de la riqueza social.

3. Más aún: por esta inversión simbólica de los términos, no es difícil ver cómo aquellos sujetos que más frecuentemente se constituían en acreedores de la acción del estado al que responsabilizaban por su omisión como prestador de políticas sociales, pasaban - en algunas versiones de la teoría - a la condición de deudores, al ser responsabilizados por los efectos que su aislamiento social podía tener en su propia suerte y la de sus hijos. Recordemos que planteos como el de Fukuyama, pero también el de muchos otros, terminan por responsabilizar a los sectores más vulnerables - en especial a las mujeres jefas de hogar - por el perjuicio que, en términos de pérdida de CS, ocasiona a los hijos el alejamiento del hombre del hogar, como consecuencia del alza en la tasa de divorcios. Los más desfavorecidos, llegan así, a convertirse en una suerte de "deudores sociales" por no asegurar a su entorno inmediato afectivo - hijos y descendientes - una red de relaciones adecuada o favorable para el aprovechamiento de la estructura de oportunidades que la sociedad, en esta perspectiva, abriría a todos, prácticamente por igual. A nivel simbólico, el estado queda así, exonerado de la responsabilidad por el bienestar social de unos sujetos que han descuidado o abandonado la pertenencia a una estructura familiar que les habría favorecido económicamente, a sí mismos o a sus hijos.

4. A nivel de la acción comunitaria, muchas organizaciones no gubernamentales, comunidades religiosas, caudillos locales, y otros grupos de acción y promoción social, de diverso tipo, procedencia y propósitos, vieron de pronto cómo su actividad cobraba nueva relevancia, y cómo esta nueva gravitación en su práctica local era además apoyada, financiada y legitimada por el flujo a veces no menor de recursos que llegaban desde un estado 
que había perdido, abandonado o anulado los viejos canales de prestación de servicios. El traspaso a las ONGs de una parte de las funciones y prestaciones que antes eran servidas por el estado, fue un modo de traspasar servicios públicos al ámbito privado (esto es, de privatizar, (McDonald y Ruiters, 2006) evitando las resistencias que generan estos procesos cuando las funciones públicas son traspasadas a grandes empresas, nacionales o trasnacionales. Mientras, las organizaciones vecinales y locales, en particular aquellas de tipo religioso, ven en estas formas de financiamiento estatal a los servicios sociales que prestan, un subsidio indirecto a una labor pastoral que había permanecido eclipsada durante largo tiempo por el apogeo del estado laico de bienestar.

5. Esto tiene múltiples impactos en los modos de visualizar a este tipo de relaciones: a) les dota de un carácter económico como generador de riqueza en sentido estricto, lo que satisface a algunos economistas; b) las resignifica como un lugar clave para el desarrollo social de las naciones, revitalizando el interés en el estudio de la sociabilidad, lo que satisface a buena parte de la comunidad sociológica; c) las revaloriza al invertir la jerarquía instaurada por la modernidad entre comunidad y asociación, devolviendo a la primera una valoración ya muy maltrecha por el ascenso de las pretensiones universalistas modernas; esto es particularmente grato a las comunidades religiosas, de acción comunitaria, de promoción social, organizaciones no gubernamentales, y otros grupos de poder y liderazgo localmente arraigados, que no sólo ven legitimada su influencia social, sino muchas veces además, la ven fortalecida por el financiamiento de su actividad regular por parte del estado y de la cooperación internacional; d) las expone como mecanismos legítimos, no sólo de generación, sino de apropiación y transmisión de la riqueza, con lo cual, -al otro extremo de la escala social, en las élites- se justifica la circulación familiar del privilegio social y político, y el aprovechamiento de las redes particularistas y exclusivas, por donde circula el grueso del poder económico, político y social.

6. Se trata, en suma, de una teoría altamente polisémica y multifuncional, que da a cada uno lo que cada uno necesita oír, cuya virtud más evidente es la de conciliar los intereses y las visiones de todos aquellos que tienen voz: las élites políticas, económicas y sociales, las organizaciones no gubernamentales, y comunales, de tipo social y religioso, y hasta a las clases medias bien insertas socialmente, obvia y comprensiblemente ajenas a la polémica, pero renuentes a soportar mayores cargas fiscales para financiar la reconstrucción del estado de bienestar.

\section{3. ¿Qué falla en la Teoría del CS?}

En este apartado nos interesa señalar algunos grandes aspectos problemáticos de la teoría del CS, como es usada actualmente.

a) En primer término, si a ciertos resultados beneficiosos de la pertenencia a grupos queremos darle el nombre de "capital", debemos ser consecuentes con el concepto e incluirlos dentro de la lógica más general de la generación del capital y de su trasmisión. Desde nuestro punto de vista, no parece plausible sostener - con Coleman, Solow, Arrow, y muchos otros - que aunque adoptamos el nombre de capital, no se trata, realmente de capital ni responde a su lógica. $\mathrm{O}$ bien subsumimos el concepto bajo la lógica del capital, en cuyo caso el concepto 
encuentra una más cómoda ubicación en el esquema conceptual de Bourdieu - que postula la dependencia de unas formas de capital de otras, su transformación recíproca y su reductibilidad última a capital financiero, y que permite visibilizar las formas invisibles de trasmisión del capital que tienen lugar por su eufemización - o, por el contrario, abandonamos la noción de capital y la sustituimos por otra que designe de modo más adecuado aquello que los autores reconocen como rasgos característicos. En nuestra perspectiva, la aproximación bourdiana es la que cumple mejor con los propósitos de iluminar los rendimientos económicos que ciertas formas de sociabilidad tienen para los individuos, así como para la mostrar la determinación social de las diferencias en dichos rendimientos.

b) En segundo lugar, para designar todas aquellas formas de ayuda, solidaridad y cooperación que los sujetos aportan en una relación que es vista por los participantes como un fin en si misma, debería bastar con los aportes conceptuales provenientes de la sociología en el estudio de las distintas formas de acción social y de sus fundamentos, en las lineas de Giddens, Beck, Archer, Bauman, Habermas y tantos otros. Una buena sociología debería preocuparse por mantener las distinciones teórica y empírica entre las relaciones proveedoras de sentido, basadas en lazos de comunidad y afecto, de aquellas relaciones de intercambio racionalmente orientadas, por citar sólo dos de los varios tipos posibles. Sólo la obsesión contable por incrementar los activos societales de países en crisis, o el interés por superar la crítica al particularismo patrimonialista de ciertas prácticas políticas, pueden justificar que ambos tipos de relaciones hayan terminado, a pesar de su larga historia como tipos polares, confundidos bajo una sola, ambigua, etiqueta.

c) En tercer lugar, la teoría tiene un evidente sesgo economicista que atenta contra la comprensión de la variedad de las motivaciones que impulsan a los actores en su relacionamiento reciproco. Una sociología que tome en cuenta las interpretaciones que los propios actores hacen de sus acciones situadas, aunque, en una doble hermenéutica, las interprete a su vez, está obligada a tomar en consideración que la mayor parte de las acciones y relaciones que la teoría visualiza en términos de "CS", son experimentadas por los actores como acciones desinteresadas, afectivas, y contrarias a todo cálculo racional. En palabras de Eduardo Vizer:

"Encuadrar las normas y los valores sociales como la confianza y la participación dentro de la noción de capital parece ser - cuando menos - algo chocante y hasta cierto punto antagónico. (...) La propuesta de adopción de la noción de capital para encuadrar teóricamente un conjunto de procesos de organización social, relaciones, creencias y valores de pertenencia y compromiso colectivo, puede distorsionar el sentido y las características que la propia comunidad - y los actores involucrados - adjudican a estas formas "vividas" de la praxis social. Hay una construcción de "sentido" fundamental por parte de los actores y de una comunidad que debe formar parte del objetivo de cualquier proyecto de investigación sobre estos procesos sociales (...) El paradigma del CS, visualizado y objetivado como una forma de capital, corre en este sentido el riesgo de "cooptar" epistemológicamente el contenido social originario de las ideas propuestas como una ontología a ser empíricamente investigada" (Vizer, 2006:304-305)

La ampliación sucesiva del concepto, cuyas fuentes y formas llegan a incluir no sólo las relaciones de confianza establecidas dentro de pequeños grupos, sino también la efectividad de las normas estatales, la eficiencia burocrática, el parentesco, los medios de comunicación y las vías de tránsito, la seguridad pública, la religión y muchos etcéteras, tiene efectos diferentes de los esperados: en lugar de brindar elementos para clarificar el análisis y la discriminación de elementos diversos, oscurece la distinción entre la acción del estado, la 
de los municipios y autoridades locales, de los particulares, de los familiares y del mercado. Como en cajón de sastre, todo parece tener cabida en la teoría: empleo, religión, barrio, familia, gobierno, carreteras. Hasta el estado y el mercado, polos antagónicos alrededor de los cuales gravitaron las propuestas de política económica en los últimos siglos, conviven ahora, dentro de una noción que tal vez deba a su increíble ambigüedad y polisemia, las razones de su indudable poder de seducción. El CS, es, en efecto, un oscuro objeto.

En definitiva, a pesar de su aparente atractivo y de su indudable éxito, la nueva teoría del CS no constituye un aporte original ni un descubrimiento de los mecanismos de organización y funcionamiento de la vida social. La sociedad, tal como la misma teoría no duda en mostrar, tiende espontáneamente, a reproducirse a sí misma, a sus desigualdades y a sus mecanismos de atracción y de expulsión, lo que tiene lugar principalmente en el seno de los pequeños micro grupos donde procesa su reproducción biológica y donde se desarrolla la sociabilidad. Todavía fuertemente influida por el enorme peso de los supuestos individualistas de la teoría económica neoclásica, y habiendo olvidado los fundamentos universalistas y los propósitos igualitaristas que legitiman a la acción del estado moderno y de las políticas públicas, la teoría pretende encontrar el camino hacia la sociedad ideal por la vía de celebrar la realidad tal cual es, reivindicando su carácter moral y legitimando, con ello, un orden social particularista y desigual. 


\section{Referências Bibliogáficas}

ARROW, Kenneth - "Observations on social capital". In DASGUPTA, Partha; SERAGELDIN, Ismail (eds.). Social Capital. A Multifaceted Perspective, Washington DC: The World Bank, 2000, pp. 3-5.

BID - Reducción de la pobreza y fortalecimiento del capital social y la participación. La acción reciente del Banco Interamericano del desarrollo. Conferencia Regional "Capital Social y Pobreza". Santiago de Chile: CEPAL, 2001.

BOURDIEU, Pierre - "Las formas del capital. Capital Económico, capital cultural y capital social". In Idem. Poder, derecho y clases sociales. Barcelona: Desclée, 2000.

CHAVEZ, Daniel (ed.) - Más allá del mercado. El futuro de los servicios públicos, Ámsterdam: TNI, 2006, pp.9-22.

COLEMAN, James S. - "Social capital in the creation of human capital". In DASGUPTA, Partha; SERAGELDIN, Ismail (eds.) Social Capital. A Multifaceted Perspective, Washington DC: The World Bank, 2000.

FUKUYAMA, Francis - Social Capital, The Tanner Lectures On Human Values. Oxford: Brasenose College, 1997.

FONTES, Breno - "Terceiro Setor, Dádiva e Redes Sociais". In Medeiros, Alzira; Martins, Paulo Henrique (Org.) Economía Popular e Solidária. Desafios Teóricos y Práticos. Recife: Bagaço, 2003.

GRANOVETTER, Mark - "Economic action and social structure: the problem of embeddedness". American Journal of Sociology, 1985, pp. 481-510.

HELIWELL, John; PUTNAM, Robert - "Economic Growth and Social Capital in Italy". In DASGUPTA, Partha; SERAGELDIN, Ismail (eds.). Social Capital. A Multifaceted Perspective, Washington DC: The World Bank, 2000, pp. 253-269.

KLIKSBERG, Bernardo; TOMASSINI, Luciano - Capital social y cultura: Claves estratégcas para el desarrollo. Mexico: BID-FCE, 2000.

MARRERO, Adriana - "La teoría del Capital Social y la Educación en Uruguay". Actas del Congreso de Sociología de la Educación. Buenos Aires: ISA, 2004.

MARRERO, Adriana - "La teoría del capital social. Una crítica en perspectiva lationamericana". Arxius. no 14, 2006, pp. 73-90.

MARTINS, Paulo Henrique - "O Estado e a redistribuiçao dos bens da cidadania no contexto pós-nacional", In MARTINS, Paulo Henrique; FERREIRA NUNES, Brasilmar (Org). A nova ordem social. Perspectivas da solidaridades contemporanea, Brasília: Paralelo 15, 2004.

MEDEIROS, Alzira; MARTINS, Paulo Henrique (Org.) - Economía Popular e Solidária. Desafios Teóricos y Práticos. Recife: Bagaço, 2003.

MCDONALD, David; RUITERS, Greg - "Teorizando la privatización: contribución al desarrollo de una perspectiva de investigación crítica", In CHAVEZ, Daniel, (ed.) Más allá del mercado. El futuro de los servicios públicos, Ámsterdam: TNI, 2006, pp.9-22.

MCKINNEY, John C. - Tipología constructiva y teoría social. Buenos Aires: Amorrortu, 1968.

PORTES, Alejandro - "Social Capital. Its Origins and Applications in Modern Sociology". Annual Reviews. 1998, pp. 1-24.

PORTUGAL, Sílvia - "Contributos para uma discussão do conceito de rede na teoria sociológica", Oficina do CES, no 271, 2007.

PUTNAM, Robert - Per a fer que la democràcia funcioni. La importància del capital social. Barcelona: Proa, 2000.

SOLOW, R. "Notes on Social Capital and economic performance". In DASGUPTA, Partha; SERAGELDIN, Ismail (eds.). Social Capital. A Multifaceted Perspective. Washington DC: The World Bank, 2000, pp. 6-13.

TRIGLIA, C. - "Capital social y desarrollo local". In BAGNASCO, Arnaldo et al.. El capital social. Instrucciones de uso. Buenos Aires: FCE, 2003.

VIZER, Eduardo - La trama (in)visible de la vida social. Buenos Aires: La Crujía, 2006. 
(Página deixada propositadamente em branco) 
Aécio Gomes de Matos

\section{Os Determinantes Sociais de Saúde}

\section{Introdução}

Historicamente, a saúde começa a ser tratada como questão de Estado ainda no século $\mathrm{XV}$, com foco no controle de doenças transmissíveis, epidemias e pestes. Uma postura típica de exclusão se transforma gradualmente em políticas públicas de cunho assistencial que se consolidam após a segunda guerra mundial com o advento do Estado do bem estar social. (Foucault, 1977).

Pode-se remarcar que as contribuições das ciências sociais para essa evolução remontam ao século XIX, no momento mesmo do nascimento da sociologia, pelas máos de um dos pais das ciências sociais, Émile Durkheim, que introduz as questóes de saúde na pauta de suas pesquisas, com o livro O Suicídio (1879), na sequência dos estudos epidemiológicos de Louis René Villermé (1782-1863) sobre morbidade e mortalidade infantil e sobre o estado físico e moral dos operários têxteis (Nunes, 2003). Nos Estados Unidos e na Inglaterra, a pesquisa social em saúde toma corpo após a segunda guerra mundial, com as perspectivas funcionalista (Talcott Parsons) e interacionista (Charles Wright Mills), para se expandir em uma grande diversidade de métodos empíricos e normativos fundamentalmente comprometidos com uma perspectiva gerencial das funções médicas, e menos com as questóes dos pacientes e das políticas públicas. Na França essas contribuições se fazem sob influência dos trabalhos de Michel Foucault (Doença Mental e Psicológica, 1997 e O Nascimento da Clínica, 2000). Diferentemente dos americanos, os franceses mantêm um enfoque mais teórico do que empírico, em prejuízo de uma evolução mais objetiva das políticas de saúde.

No Brasil, o Primeiro Congresso Brasileiro de Ciências Sociais em Saúde, em 1995, marca o engajamento definitivo da sociologia com as questóes de saúde, consolidando uma tendência dos anos 80 de superar os limites dos métodos quantitativos como instrumento de avaliação dos serviços de saúde e impor um paradigma humanizante (Abrasco, 2005). Essa nova perspectiva qualitativa e dialética da pesquisa social em saúde procura analisar a cultura institucional e a prática dos agentes, inclusive a dos movimentos sociais e da conjuntura histórica, como sujeitos sociais ativos (Deslandes, 1997).

Muito antes da criação do Sistema Único de Saúde (SUS), numa ampla revisão da bibliografia internacional sobre a questão, Araújo (1975) destaca uma relação direta entre saúde e desenvolvimento econômico, ressaltando, com a linguagem dos modelos econométricos, a importância da aplicação prática deste tipo de análise na elaboração de políticas e no processo de tomada de decisóes planejadas. Como para esse autor não haviam ficado 
claras as evidências das contribuiçóes da saúde para o desenvolvimento da economia, ele alerta para o risco do setor de saúde ficar marginalizado na competição de recursos escassos, perdendo espaço, inclusive nas políticas públicas, para aqueles setores que se demonstrassem economicamente mais consequentes para as prioridades desenvolvimentistas.

De fato, esse alerta não era desprovido de razão. Já na década de 90 , no início do declínio do Estado do bem estar social, a lógica neoliberal que passa a comandar as políticas públicas, tanto na Europa Ocidental quanto na América do Norte, tende a reduzir o papel do Estado nas atividades previdenciárias e na saúde, evidenciando três questóes de ordem estrutural. A primeira tem a ver com a coorte demográfica, considerando o envelhecimento progressivo e a redução da população economicamente ativa, associada à degradação quantitativa e qualitativa do emprego; a segunda diz respeito à perda da capacidade do Estado de financiar as prestaçóes do sistema de saúde e de outros direitos sociais que foram conquistas da sociedade civil assumidas pelas instituiçóes do Estado do bem estar social; a terceira está associada ao nível crescente de complexidade e de custos dos serviços médicos, com tecnologias cada dia mais sofisticadas e mais caras, que passam a incorporar novas demandas de um público cada dia mais informado e mais exigente (Silva, 2003). Essas são questóes pendentes em todo o mundo, inclusive nos países desenvolvidos.

\section{Um novo paradigma}

Até a constituição de 1988, o sistema de saúde no Brasil se caracterizava pela ineficiência, pela precariedade dos serviços e pela falta de financiamento das estruturas operacionais, dos quadros profissionais e de suas competências. Essa situação era agravada pela centralização dos recursos da previdência social nas organizaçóes federais ligadas ao Instituto Nacional de Assistência Médica da Previdência Social. Apesar do orçamento ser centralizado, operacionalmente o sistema de saúde se assentava desordenadamente em estruturas federais, estaduais e municipais que funcionavam sem sintonia e com uma grande desarticulação funcional, cada um fazia o que podia, com superposiçóes e vazios. A demanda se orientava prioritariamente para unidades de saúde de maior complexidade e de mais notoriedade. A desarticulaçáo institucional se expressava ainda na falta de controle político, social e financeiro, o que contribuía ainda mais para comprometer a efetividade dos serviços de saúde.

Criado pela constituição de 1988, em decorrência das lutas sociais pela reforma sanitária, o Sistema Único de Saúde (SUS) teve como princípios fundadores a universalidade, a equidade e a integralidade dos serviços de saúde, incluídos na Constituição de 1988 como direito de todos e dever do Estado. Rompendo conceitualmente com os modelos centrados sobre os paradigmas de saúde-doença, a descentralização das açóes primárias de saúde para a esfera municipal representou uma estratégia de articulação dos esforços institucionais nos diversos níveis da federação, com controle social se expressavam nos conselhos gestores e nas conferências de saúde.

O Programa de Saúde na Família permitiria o desenvolvimento de açóes preventivas de saúde e um sistema de atendimento imediato para procedimentos de baixa complexidade, estabelecendo critérios de triagem e encaminhamento dos problemas de média e alta complexidade para os núcleos especializados. $\mathrm{O}$ modelo estava bem concebido e da sua implementação resultou uma melhora substancial da saúde publica, em particular para as populaçóes mais pobres, antes relegadas a filas quilométricas e ao mau atendimento. 
Pesquisa realizada pelo IBOPE ${ }^{1}$, em todo o País, mostra que o atendimento nas unidades públicas de saúde é considerado como bom ou ótimo por $83 \%$ dos usuários, mas $74 \%$ dos entrevistados afirmam que, se tivessem oportunidade, procurariam serviços particulares. O índice é mais elevado entre os usuários com mais de cinquenta anos e entre os que têm até o curso primário completo.

Apesar da clareza das intençôes e da montagem institucional dos modelos de atendimento desde os anos 90, a diferença entre a concepção do modelo e sua aplicação prática chama a atenção de analistas como Elias (2004) para quem, depois de dez anos de implantação do SUS, "a atenção à saúde continua sendo operacionalizada através de um sistema segmentado e desarticulado", sofrendo ainda dos mesmos males que justificaram a sua criação. Para esse autor, o SUS, diante da grande exclusão social, dos interesses privados e da tecno-burocracia se caracteriza como um sistema segmentado e seletivo, universalizando uma assistência básica nivelada por baixo, como um apartheid social na saúde.

Segundo informaçóes do DATASUS, em abril de 2006 estavam cadastrados como usuárias do SUS cerca de 27,5 milhôes de famílias, ou seja, mais de 70\% das famílias brasileiras. Para Silva (2003) pesquisa realizada pelo IBOPE em 1998, sob demanda da Fundação Nacional de Saúde, a "cobertura real do SUS pode ser ainda menor do que os estimados 99 milhöes de brasileiros”, $28 \%$ dos quais usariam exclusivamente os serviços públicos de saúde. Ele argumenta que existem indícios evidentes de que uma parte significativa das populaçôes mais carentes, com menor renda, menor escolaridade, vivendo em áreas mais remotas, não teria acesso ao sistema público de saúde, sobretudo aos serviços de maior complexidade.

O orçamento é um dos limites maiores para o aperfeiçoamento e a expansão do sistema de saúde pública no Brasil. Segundo o Relatório sobre a Saúde 2006, da OMS, o setor público brasileiro despende cerca de US\$270 anuais per capita (a valores do câmbio internacional), o que representa cerca de 36,5 bilhóes de reais no orçamento da União em 2005. Observe-se que a saúde é a rubrica mais elevada das despesas da União, duas vezes superior ao valor reservado à educação.

Mesmo reconhecendo os limites orçamentários, tudo indica que para o aperfeiçoamento do SUS e em particular de programas como o PSF, não dependem apenas de mais recursos orçamentários. Em primeiro lugar, é preciso reconhecer que o modelo de atendimento traçado pelo novo paradigma de saúde, pautado pelos princípios de universalidade, equidade e integralidade, passa necessariamente pela interação nas comunidades e pela forma como se constituíram sujeitos coletivos com uma consciência crítica da sua própria realidade e sua relação, enquanto sociedade civil, com o Estado e com seus agentes de campo.

Os resultados de uma pesquisa sobre "Redes Sociais e Saúde" que estamos desenvolvendo com financiamento do CNPq indicam que, apesar dos avanços que o SUS representa em relação aos modelos anteriores de saúde pública no Brasil, ainda há muito que se aperfeiçoar. Já temos indícios claros, por exemplo, que além das questôes orçamentárias e organizacionais que limitam os serviços prestados, a organização familiar e comunitária pode repercutir diretamente sobre a qualidade da saúde dessas populaçóes SUS-dependentes.

Um dos pontos críticos apontados é a limitação da abordagem familiar. Apesar do compromisso com a família já aparecer expresso no próprio nome de um dos programas prioritários do sistema de saúde, Programa de Saúde da Família, não existe uma prática efetiva de

${ }^{1}$ Na seção: Opiniāo Pública - Área: Análises e Índices\2000. Data de publicação: 01/05/2000 (IBOPE, 2000). 
atendimento direcionado integralmente para a família. As equipes médicas trabalham sob pressão da demanda em atendimento individualizado. $\mathrm{O}$ foco central do que poderia ser mais próximo de um atendimento familiar se restringe, na maioria dos casos, ao acompanhamento materno-infantil, quase sempre no posto de saúde. A capacidade de trabalho das equipes praticamente se esgota consultas ambulatoriais. Além da falta de tempo, observa-se deficiência de formação e de vocação para uma medicina social.

Nesse contexto seria oportuno lembrar que nos ambientes mais pobres, nos rincôes mais remotos, antes da medicina chegar com o seu saber especializado, é na família e na comunidade que se encontram os fundamentos tradicionais dos cuidados com a saúde das populaçóes economicamente excluídas. O saber popular depositado em rezadeiras e pais e máes de santo, por mais precário que seja, e a solidariedade dos parentescos e compadrios constituem a base do "sistema de saúde" popular. Na prática, no entanto, em vez de reforçar os modelos de solidariedade existentes a institucionalização do SUS termina reforçando relaçóes de dependência que associam, de um lado, deficiências educacionais, insuficiências de renda, precariedade do habitat, insegurança alimentar e, do outro, um sistema de saúde com limitaçóes estruturais, problemas de qualificação e vocaçóes profissionais.

\section{Os determinantes sociais em saúde}

A temática dos determinantes sociais surge no âmbito da Organização Mundial de Saúde em 2005 e no Brasil em 2006. Documento apresentado no lançamento da Comissão Nacional sobre Determinantes Sociais da Saúde do Brasil, em março de 2006, ressalta que "as iniquidades em saúde entre grupos e indivíduos, além de sistemáticas e relevantes são também evitáveis, injustas e desnecessárias". Este mesmo documento lembra "que o fator mais importante para explicar a situação geral de saúde de um país não é sua riqueza total, mas a maneira como ela se distribui".

Segundo o Jornal da Ciência (e-mail 3023, de 25 de Maio de 2006), os objetivos dessas comissões têm como foco central a formulação de políticas públicas que considerem os determinantes sociais em saúde como base para um amplo debate social que possa selar compromissos de médio e longo prazo com vistas a incorporar as desigualdades em saúde como tema central da agenda política. No Brasil, a pauta prioritária da Comissão visa a introduzir indicadores sócio-demográficos nos sistemas de informação oficiais da saúde, de forma a permitir o monitoramento das desigualdades sociais em saúde, tornando essa questão como um dos pontos chaves do debate sobre saúde pública e na formação dos profissionais, inclusive com incentivo à pesquisa científica.

De fato, o foco nos determinantes sociais remete a uma análise crítica das políticas públicas de saúde que se limitam aos aspectos médicos e sanitários, sem uma maior atenção para as questóes de âmbito social, econômico e político das populaçóes e, em particular, do envolvimento das famílias e das comunidades.

As correlaçôes entre as condições de iniquidades sociais e a saúde das populaçôes foram estudadas por muitos autores. Szwarcwald (2005) constata que vários estudos epidemiológicos têm estabelecido correlaçóes entre as desigualdades de saúde das populaçóes e fatores sociais e econômicos como renda, ocupação, educaçáo, habitação, ambiente determinante das condiçóes de vida. Para essa autora, 
"Consensualmente, estes estudos mostram que a saúde da população apresenta forte gradiente social que se reproduz nos mais diferentes países, independentemente da natureza, abrangência, eficácia e eficiência dos respectivos sistemas de saúde. Invariavelmente desfavorável aos grupos socialmente menos privilegiados, a falta de equidade social no âmbito da saúde manifesta-se tanto nos diferenciais encontrados nas taxas de morbi-mortalidade como no adoecimento mais precoce das camadas menos favorecidas."

Para Nunes (2003), existe certo consenso quanto ao caráter moral e de justiça social das políticas de equidade que visam reduzir a influência das diferenças sociais sobre as condiçôes de saúde das populaçóes mais pobres, sujeitas a condiçóes de vida e de trabalho estressantes e com dificuldades de acessos aos recursos materiais e aos produtos sociais resultantes daqueles recursos.

No estudo sobre desigualdades de renda e condição de saúde, Szwarcwald (2005) considera como indicadores o coeficiente de mortalidade infantil; a taxa de mortalidade padronizada por idade; a esperança de vida ao nascer e a taxa de homicídios. Como indicadores de distribuição de renda, usa o índice Gini; o índice de Robin-Hood (transferência de renda dos mais ricos para os mais pobres para atingir a equidade); a relaçâo entre a renda dos $10 \%$ mais ricos e dos $40 \%$ mais pobres. Neste estudo ela utiliza ainda outros indicadores sócio-demográficos como a taxa de analfabetismo; o índice de pobreza (renda domiciliar abaixo de 1 salário mínimo), renda média das famílias; densidade demográfica; densidade da população favelada.

Giatti \& Barreto (2006) revelam que, no Brasil, a precariedade da posição dos indivíduos no mercado de trabalho resulta em condiçôes de iniquidades de saúde, justificando a inclusáo desse indicador social como um dos importantes determinantes de saúde.

Por seu lado, Faerstein, Chor \& Lopes (2005) desenvolveram um estudo com foco nas condiçốes sócio-econômicas de origem e destino, gênero, raça/etnia e de outras dimensóes da vida social como mobilidade geográfica e social, experiência de discriminação, estresse no trabalho, padróes de rede de apoio social e sua relação com situaçóes de morbidade como a obesidade, a hipertensão, acidentes, transtornos mentais. Depois compararam essas condiçóes com os comportamentos relacionados aos cuidados de saúde, como a prática de atividades físicas, os padrôes de dieta e tabagismo e com a utilização de procedimentos, serviços e medicamentos.

A conclusão de todos esses autores é que as questóes de saúde precisam ser analisadas e tratadas numa perspectiva multifatorial, articulando indicadores de morbidade e mortalidade a outros indicadores sócio-econômicos e comportamentais. Estudos que associem análises estatísticas a estudos qualitativos, sem perder de vista os aspectos subjetivos envolvidos.

\section{O caráter político dos determinantes sociais}

É importante associar aos indicadores típicos das condiçôes sócio-econômicas e comportamentais, outros indicadores de caráter político. De fato, nossas análises indicam que o posicionamento das populaçóes no quadro político e, em particular, sua condição de influenciar as decisóes institucionais, tem uma correlação direta com o acesso e a qualidade dos serviços de saúde; quanto mais isoladas elas estiverem no quadro político, quanto menos capital social elas controlem, piores são as suas condiçóes de saúde (Matos, 2006). 
Neste sentido há que se investir em estudos com foco na constituição de sujeitos coletivos nas comunidades, como unidades auto-reguladas, exprimindo-se pelo reconhecimento recíproco e por sentimento de inclusão, que se caracteriza pelo uso da primeira pessoa do plural, "nós", foi desenvolvido por Barus-Michel (1987: 27),

[...] ao contrário do sujeito individual, o sujeito social não se define a partir de um substrato orgânico que lhe garantiria a integridade. É apenas uma organizaçáo, uma unidade postulada, construída, que pretende se garantir a si mesma, para estabelecer a lei que especifica o social.

Nesta perspectiva, a análise das condiçóes de saúde de uma população extrapola os indicadores sociais típicos de renda, educação e qualidade de vida, para assumir um caráter mais amplo onde se incluem, em particular, as questóes políticas e o acesso dos sujeitos coletivos aos dispositivos de poder que decidem sobre as políticas e sobre os processos operacionais dos programas de saúde.

Embora esteja na base na concepção do novo modelo de saúde definido com o SUS, essa condição de autonomia política da gestão do sistema não parece ter sido resolvida com a implementação dos espaços institucionais de controle da sociedade sobre as políticas de saúde. De fato, os conselhos de saúde no âmbito do SUS, não se demonstram efetivos como dispositivo de decisão nas instâncias da União, dos Estados e municípios. A concepção dos programas, as prioridades e as alocaçóes orçamentárias continuam sendo decididas nos escalóes dos ministérios e secretarias governamentais.

Para Cortes (2002) a democratização da gestão dos sistemas de saúde pública é limitada pela morosidade da descentralização do SUS para o nível municipal, onde as estruturas de gestão parecem mais permeáveis à pressão social. Por outro lado, Ribeiro (1997) afirma que, apesar dos Conselhos terem sido constituídos sob pressão popular, não se pode desconhecer o papel dominante do Estado na definição dos espaços de participação e do status de representação dos grupos de interesse e da própria agenda política dos conselhos gestores. $\mathrm{Na}$ prática, os conselhos interferem, sobretudo, no plano operacional, ora nas decisóes para priorizar a aplicação dos recursos orçamentários; ora na geração de informações da comunidade, úteis ao controle social. Uma participação limitada que, mesmo tendo o seu lado positivo, náo pode ser considerada como uma mudança significativa para a evoluçáo da democracia no País.

Pelo que estamos podendo constatar nas nossas pesquisas atuais, a democratização da gestão do sistema de saúde e, sobretudo o desejável controle social, não nos parecem tão evidentes. A falta de representatividade e de qualificação dos conselheiros (exigindo constantes programas de capacitação); o corporativismo dos trabalhadores e o poder diferenciado dos gestores nas decisóes estratégicas e na alocação de recursos criam um ambiente muito pouco favorável ao exercício da democracia.

Mas essa não é uma coisa nova nas políticas sociais. Para Gohn (2000), o surgimento dos conselhos na gestáo pública ou em coletivos da sociedade civil é tão antigo quanto a democracia representativa, remontando ao período medieval. Evoluíram na história e foram tratados diferentemente, ora como instrumentos de colaboração na filosofia liberal, ora como dispositivos políticos para impor a vontade popular pelas esquerdas. Para Hannah Arendt (apud Gohn, 2000), os conselhos consistiriam na única forma política para o exercício de um governo que tenha como princípio a participação e a cidadania.Dessa forma, as fragilidades desses processos de representatividade da população estariam afetando a efeti- 
vidade da cidadania em saúde para os segmentos sociais mais desfavorecidos da população. Um aspecto digno de referência das nossas observaçóes sobre essa questão é que, enquanto as vanguardas, militância política e a classe média esclarecida enaltecem os processos participativos em conselhos e conferências como condição de democracia, a maioria da população parece não valorizar tanto esses mecanismos de participação; uma resistência passiva de descrédito num sistema institucional onde a política se submete ao domínio da economia; onde a cidadania padece sob a discriminação social, enquanto o desemprego e a violência institucional fazem parte do dia a dia, sem nenhuma perspectiva de mudança substantiva.

A participação social apontada como um dos fatores de democratização da saúde termina sendo comprometida pelas dificuldades de expressão política de uma população com precariedade de organização e que se deixa representar sem estabelecer uma vontade política expressa em compromissos coletivos minimamente efetivos.

\section{A organizaçáo política da populaçáo}

Em um texto anterior, procurei analisar esse processo de organização social fazendo a distinção entre três níveis complementares que integram as dimensóes macro e micro sem escamotear as diferenças e contradiçôes dialéticas entre a sociedade como um todo e as instâncias que constituem a base da análise (Matos, 2003). A distinção que fiz entre a organização de massas, a organização político-institucional e a organização de base, nessa pesquisa, corresponde a um investimento mais determinado na organização de base, onde espero encontrar as referências de construção de uma democracia da saúde. Sem desprezar as formas de organização institucional e de massa, penso que é no plano da base da sociedade, no plano comunitário das relaçôes entre conhecidos que se pode constituir uma instância de organização política para trabalhar questóes mais diretamente ligadas à operação de sistemas como o SUS que afetam diretamente as pessoas, as famílias e os grupos sociais mais definidos.

É justamente nesse nível de organização comunitária, onde a consciência coletiva pode superar o "senso comum" (Gramsci, 1986), com uma análise crítica da realidade, uma postura política que se compreende o espaço do sujeito e do objeto numa práxis comprometida com a autonomia e a redução da alienaçáo dos atores sociais diante das estruturas de poder dominantes. Práxis que Castoriadis (1975), compreende como "o fazer, onde o outro ou os outros são vistos como seres autônomos e considerados como agente essencial do desenvolvimento de sua própria autonomia”. O objeto das políticas públicas assumindo, ao mesmo tempo, a posição de sujeito de sua própria história, provocando uma nova ruptura na construção social.

Para abordar essa questão do ponto de vista das populaçóes envolvidas, o foco nos sujeitos coletivos exige um referencial teórico e operacional centrado sobre os processos de organização da população. Nesse sentido, parece útil trabalhar as condiçóes em que os grupos comunitários se articulam para açóes coletivas; em que bases constituem suas referências de coesão; qual a consistência e a sustentabilidade das suas posiçóes de poder.

Proponho, para essas análises, o conceito de organizador social que utilizei em estudos sobre comunidades (Matos, 2004) para compreender os processos internos da organização dos grupos sociais, cuja diversidade aparece de maneira mais ou menos generalizada como dispositivos instrumentais, com a predominância da racionalidade; como dispositivos 
simbólicos, respaldando sentimentos de pertencimento; como dispositivos imaginários, enquanto processos inconscientes de identificação coletiva.

Cada um desses dispositivos se constitui como organizadores sociais com características e funçóes próprias e aparecem em momentos precisos respondendo pela articulaçáo coletiva nas relaçóes internas da comunidade e nas relaçóes da comunidade com os agentes externos. Nossas análises demonstraram que esses diversos organizadores coexistem simultaneamente num mesmo espaço comunitário, reforçando-se ou contrapondo-se com maior ou menor efetividade e eficiência operativa. Na prática, apesar dos aspectos contraditórios em muitas situaçóes, esses organizadores traduzem estratégias articuladas que explicam a evolução das lutas sociais, da organização comunitária, das relaçóes com as instituiçóes públicas e suas políticas, nas relaçóes com a sociedade civil.

O nosso interesse particular nesses organizadores para o estudo dos determinantes sociais de saúde reside nas possibilidades concretas de estabelecer correlaçóes entre as estruturas de poder da organização coletiva da comunidade, as condiçóes de acesso ao sistema de saúde e a capacidade de transformação que essa comunidade passa a deter para produzir mudanças na situação de outros organizadores sociais que determinam suas condiçóes de vida e sua saúde. Esses determinantes políticos estariam assim numa linha diferenciada de determinação, podendo influenciar diretamente outros determinantes sociais de saúde. Seriam assim determinantes sociais de segundo nível.

O cuidado com esses determinantes políticos se justifica porque, na situação brasilei$\mathrm{ra}$, as fragilidades da uma democracia erigida sob as assimetrias sociais não deixa muitas esperanças aos que acreditam no futuro de instituiçôes como o SUS. Sem contestar essas desconfianças perante o ufanismo vazio da classe política que alimenta projetos de poder, há que se ir além da desesperança, à cata de uma análise mais acurada que permita fundar projetos mais animadores. Há que se interrogar sobre os limites da organização social e sobre o seu poder de transformação; em última instância, sua vocação revolucionária.

O olhar para os determinantes políticos através dos organizadores sociais se associa à análise da coesão política dos grupos comunitários diante das condiçóes de iniquidades sociais e, em particular, das condiçóes de atendimento oferecidas pelo sistema de saúde. Considerando que a vontade político-institucional expressa na constituição de um sistema de saúde pautado por princípios democráticos parece insuficiente para garantir sua implementação de maneira coerente, a vontade da população precisa se expressar de maneira mais peremptória e decisiva. Em outras palavras, a participação social precisa ser ordenada a partir da base comunitária como dispositivo político transformador que permita superar os limites da democracia representativa e os desvios da democracia participativa.

Investir no desenvolvimento político das comunidades organizadas com autonomia local parece ser assim um caminho incontornável para implementação de um novo modelo de saúde pautado na universalidade, na equidade e na complementaridade, como pretenderam os que imaginaram e conceberam o Sistema Único de Saúde no Brasil. 


\section{Referências Bibliográficas}

ABRASCO - Boletim 95. III Congresso Brasileiro de Ciências Sociais e Humanas em Saúde. Ano XXI, Dezembro 2005.

ARAUJO, José Duarte de - "Saúde e desenvolvimento econômico: atualizaçẫo de um tema". Revista de Saúde Pública. vol.9, no 4, 1975, pp.515-528.

BANCO MUNDIAL - Relatório Desigualdade na América Latina e no Caribe "Rompendo com a história", 2003.

BANCO MUNDIAL - World development report 2006 - Equity and Developmen, 2006.

BARUS-MICHEL, Jacqueline - Le Sujet Social. Étude de Psychologie Sociale Clinique. Paris: Dunod, 1987.

CASTORIADIS, Cornélius - L'Institution Imaginaire de la Société. Paris: Éditions du Seuil, 1975.

CORTES, Soraya Maria Vargas - "Construindo a possibilidade da participação dos usuários: conselhos e conferências no Sistema Único de Saúde”. Sociologias, no 7, 2002, pp.18-49.

DESLANDES, Suely Ferreira - "Concepçóes em pesquisa social: articulações com o campo da avaliação em serviços de saúde", Cadernos de Saúde Pública, 13 (1), 1997, pp. 103-107.

ELIAS, Paulo Eduardo - "Estado e saúde: os desafios do Brasil contemporâneo". São Paulo Perspectivas. Vol. 18, no 3, 2004, pp. 41-46.

FAERSTEIN, Eduardo; CHOR, Dora; LOPES, Claudia de Souza et al. - "Estudo Pró-Saúde: características gerais e aspectos metodológicos". Revista Brasileira de Epidemiologia. vol.8, no 4, 2005, pp. 454-466.

FOUCAULT, Michel - O nascimento da clínica. Rio de Janeiro: Forense Universitária, 1977.

GIATTI, Luana; BARRETO, Sandhi Maria - "Situação do indivíduo no mercado de trabalho e iniquidade em saúde no Brasil”. Revista de Saúde Pública, vol.40, n¹, 2006, pp.99-106.

GOHN, Maria da Glória - O papel dos conselhos gestores na gestấo urbana. En publicacion: Repensando la experiencia urbana de América Latina: cuestiones, conceptos y valores. Ana Clara Torres Ribeiro. CLACSO. 2000. ISBN: 950-9231-52-5 Acceso: http://bibliotecavirtual.clacso.org.ar/ar/libros/urbano/gohn.pdf

GRAMSCI, Antonio - Concepção Dialética da História. 6a ed. Rio de Janeiro: Civilização Brasileira, 1986.

IBOPE - Promoção da saúde: pesquisa de opiniāo pública. São Paulo: IBOPE, 2000.

MATOS, Aécio Gomes de - "Participação e democracia". In MARTINS, Paulo Henrique ; FONTES, Breno. Redes, práticas associativas e gestáo pública. Recife: Editora Universitária da UFPE, 2006.

MATOS, Aécio Gomes de - Organização social de base: reflexóes sobre significados e métodos. Brasília: Editora Aboré, 2003.

MATOS, Aécio Gomes de - "Organizadores sociais: Algumas referências conceituais para análise das organizaçōes sociais”. Revista Estudos de Sociologia. Vol. 10, no 1/2, 2004, pp. 123-153.

NUNES, Everardo Duarte - "A sociologia da saúde nos Estados Unidos, Grä-Bretanha e França: panorama geral”. Ciência saúde coletiva. $\mathrm{n}^{\circ} 1,2003$, pp.79-95.

RIBEIRO, José Mendes - "Conselhos de saúde, comissóes intergestores e grupos de interesses no Sistema Único de Saúde (SUS)”. Cadernos de Saúde Pública. Vol.13, nº 1, 1997.

SILVA, Pedro Luiz Barros - "Serviços de Saúde: o dilema do SUS na nova década". Sáo Paulo Perspectivas. vol.17, no 1,2003 , pp.69-85.

SZWARCWALD, Célia Landmann; LEAL, Maria do Carmo; GOUVEIA, Giselle Campozana et al. (2005) "Desigualdades socioeconômicas em saúde no Brasil: resultados da Pesquisa Mundial de Saúde, 2003". Revista Brasileira de Saúde Materno- Infantil. Vol. 5, supl.1, 2005, pp.s11-s22. 
(Página deixada propositadamente em branco) 
Maria José Hespanha e Pedro Hespanha

\section{O PAPEL DAS REDES SOCIAIS NAS POLÍTICAS SOCIAIS. O caso da Rede Nacional de Cuidados Continuados Integrados}

\section{Introduçáo}

Nos últimos anos, temos vindo a assistir a uma crescente preocupação dos sucessivos governos com a escassez da oferta de cuidados continuados para as pessoas dependentes e a tentativas sucessivas de encontrar respostas eficazes para estas pessoas.

Todos sabemos que as condiçóes para ajudar as pessoas dependentes, na sua grande maioria idosos, têm vindo a piorar, não só porque as condições de trabalho dos familiares levam a uma crescente indisponibilidade de tempo, mas ainda devido a razóes mais gerais que têm a ver com os novos regimes demográficos. Assim, ao aumento da população idosa acresce a redução da população que pode prestar apoio, em virtude da conjugaçáo de uma série de factores, dentre os quais o declínio da taxa de natalidade, o retardamento da idade de procriação, o aumento do divórcio e das famílias monoparentais, o aumento da participação da mulher no mercado de trabalho, etc.

O problema principal é que as famílias contemporâneas não têm condiçôes para cuidar dos seus dependentes, assim como dificilmente conseguem assumir o acompanhamento dos seus idosos e que, para além da família, poucas são as instituiçóes capazes de assegurar os cuidados de que esta população necessita. A acrescentar a este problema encontra-se o facto da maioria dos idosos serem pobres e não terem possibilidade de proverem todos os cuidados de que necessitam no seu quotidiano. A taxa de pobreza dos idosos em Portugal em 2005 - 28\% é bem mais elevada que a média - 20\% (UE15 - 20\%) (EUROSTAT, 2007).

O acompanhamento dos idosos e dos dependentes tem estado a cargo dos sistemas de saúde e de segurança social, mediante intervençóes parcelares e respostas imediatas para problemas complexos de sobrevivência.

O sistema de saúde, durante muitas décadas estruturado num modelo hospitalocentrico onde a dimensão "caso clínico" era mais importante do que a dimensão "pessoa", teve de se adaptar ao surgimento dos cuidados de saúde primários e à necessidade de integrar a perspectiva bio-psico-social da doença que estes seguem e começa agora a conviver com uma nova realidade: a procura de soluçóes por parte de uma população muito idosa que entra nos hospitais, ocupa camas, sobrecarrega os profissionais devido aos níveis de dependência que apresenta e sem grande hipótese de sucesso terapêutico. Neste quadro, pede-se ao sistema de saúde que dê uma resposta que respeite, simultaneamente, a necessidade de prestar cuidados de qualidade e especializados a esta população, de criar instituições ade- 
quadas a prestar esses cuidados por forma a reservar os hospitais para episódios de doença aguda, de aliviar as famílias do encargo pesado de cuidar dos seus familiares dependentes de cuidados continuados e relativamente especializados e de integrar as ajudas que o sector social presta aos doentes e suas famílias.

Essa resposta consiste nos cuidados continuados e tem vindo, em muitos países, a tornar-se uma área central dos cuidados de saúde. Em Portugal é o Programa Rede Nacional de Cuidados Continuados Integrados (RNCCI), recentemente criado na sequência de outras medidas menos estruturadas, que dá corpo a esta nova área de intervenção.

Existe, porém, a nível internacional uma grande ambiguidade na delimitação desta área dos cuidados e uma grande diversidade de modelos de intervenção, com diferente participação da esfera pública, das organizaçôes da sociedadee civil e das famílias.

O objectivo deste texto é, a partir da noção de rede social, analisar as formas institucionais e não institucionais de prestação de cuidados continuados e reflectir, para o caso português, sobre o sentido de algumas opçóes tomadas na construção do modelo de prestação de cuidados (RNCCI) quer quanto ao desenho da rede institucional, quer quanto ao reconhecimento das redes informais de cuidados.

Começaremos por abordar a questão da ambiguidade conceptual que rodeia este tipo de cuidados e discutir os diferentes objectivos visados pelas políticas que os pretendem desenvolver, nem sempre coerentes entre si e dominados por preocupaçóes diversas. A seguir será valorizada a questáo dos modelos prevalecentes na protecção social e, designadamente, a do papel e responsabilidade atribuídos ao Estado neste domínio mais específico dos cuidados continuados de saúde e de bem-estar social. Finalmente será apresentado o programa da Rede de Cuidados Continuados e Integrados, discutindo, a propósito, as implicaçóes que decorrem do modelo escolhido em Portugal - uma rede institucional de serviços e equipamentos à escala nacional e uma rede de parceiros cooperando de uma forma articulada e integrada à escala local - para a sua concretização prática, tendo em conta as necessidades e as expectativas dos cidadãos, dos profissionais e das Instituiçóes.

\section{Um campo de limites imprecisos}

Uma pesquisa sobre as designaçôes usadas nos diferentes países para os cuidados continuados revela a diversidade das designaçóes e a imprecisão dos seus limites. Em parte explicada pela história da intervenção em cada país, a diversidade tem ainda a ver com a natureza e configuração dos sistemas de protecção social e também com as orientaçóes ditadas pelas organizaçôes internacionais ${ }^{1}$.

Dentre as designações mais usadas quer pelos Estados quer pelas organizaçôes internacionais, contam-se as de "cuidados continuados" (continuing care), "cuidados de longa duração" (long-term care) e "cuidados integrados" (integrated care), cada uma delas reflectindo objectivos que, nas situaçóes reais, se encontram quase sempre sobrepostos.

Sem menosprezar a dificuldade das definiçóes, poder-se-ia caracterizar, de uma forma sintética, os três tipos de cuidados nos seguintes termos.

\footnotetext{
1 Mais recentemente organizaçóes internacionais como a OMS, a OCDE e a Uniăo Europeia têm vindo também a ocupar-se do tema e, por essa via, a fixarem terminologias e conteúdos de acçáo.
} 
Os cuidados continuados visam apoiar pessoas com necessidades que se prolongam por uma duração que não sendo necessariamente longa exigem um acompanhamento ao longo de um certo tempo. Na definição do Instituto de Medicina de Washington eles consistem "numa variedade de serviços continuados de saúde e sociais, prestados a indivíduos que precisam de assistência numa base continuada em virtude de um problema físico ou psicológico. Os serviços podem ser prestados numa instituição, no domicílio ou em centros comunitários". Cabem nesta designação as situaçôes mais diversas. Categorias de pessoas como idosos, pessoas com deficiência física ou mental, todas elas caracterizadas por necessitarem de cuidados regulares. Os cuidados continuados consistem num conjunto de serviços e processos de cuidar orientados para pessoas com necessidades semelhantes. Esses serviços tanto podem consistir em cuidados domiciliários de enfermagem ou saúde e acompanhamento social, como em alojamento, transporte, fornecimento de refeiçóes ou actividades ocupacionais, podendo exigir ou não qualificaçóes técnicas elevadas e pertencer ao domínio dos cuidados de saúde ou dos cuidados sociais.

A dificuldade em comparar este tipo de cuidados de país para país pode ser explicada por muitos factores: a) os serviços estão frequentemente dispersos por diferentes organismos públicos e privados; b) o sistema de cuidados é muito influenciado pela existência ou não de uma cultura de cuidados informais ou familiares como acontece nos países do sul da Europa; c) estes sistemas têm estado a ser objecto de reformas ou de expansão com contornos muito diferenciados; d) o papel dos cuidados de saúde relativamente aos de outras instituiçôes como os serviços sociais varia muito de país para país; e) finalmente os sistemas de cuidados assumem configuraçóes muito distintas conforme o modelo de protecção social que vigore num país (modelo universalista, financiado por impostos; modelo corporativo financiado pelas contribuiçôes de seguro obrigatório; modelo liberal de escasso financiamento público) ou combinam vários modelos de protecção social.

Os cuidados de longa duração não se distinguem claramente dos anteriores e, com frequência, se usa esta designação para as acçóes que configuram os cuidados continuados. Acresce que esta designação está a ser cada vez mais usada pelas organizaçóes internacionais (OECD, 2005). A característica mais marcante é o facto de os cuidados de longa duração se dirigirem a situaçôes de dependência prolongada no tempo e não a situaçóes de dependência esporádica e facilmente resolúvel no quadro das respostas hospitalares ou comunitárias existentes. Porém, o que conta mais é o carácter agudo ou dificilmente gerível da situação de dependência pela família, mesmo quando a duração expectável da dependência não seja muito longa. Do ponto de vista dos conteúdos, é frequente estes cuidados compreenderem cuidados náo especializados de vigilância e acompanhamento de tarefas diárias da pessoa dependente (como vestir-se, tomar banho ou serviços de higiene), para além de cuidados médicos e de enfermagem.

Os cuidados integrados visam prestar serviços adequados à muitidimensionalidade dos problemas da populaçáo alvo dos cuidados, nomeadamente a população idosa e dependente, ou seja, integrar as respostas médicas, sociais ou outras nos serviços prestados. Sabe-se como o envelhecimento da população está a tornar cada vez mais complexa e diversificada a resposta dos serviços, em grande parte porque persiste uma oferta fragmentada e dispersa desses serviços. Este objectivo tem-se revelado difícil de atingir particularmente nos países em que os cuidados sociais e os cuidados de saúde pertencem a ministérios distintos. Nestes casos o desafio consiste em gerar arranjos inter institucionais (por meio de protocolos ou de equipas multidisciplinares), em garantir compromissos entre as instituiçóes (pelo reforço 
da confiança mútua e da cooperação) e em explorar as boas práticas (através de um processo contínuo de aprendizagem e avaliação) (Van Raak et al. 2003). Também as relações entre parceiros públicos e parceiros privados depende de um quadro claro de regulação entre ambos e de um clima de confiança recíproca no respeito da autonomia e da missão de cada parceiro.

O facto de a estrutura de cuidados de saúde para problemas relacionados com o envelhecimento e a dependência se ter modificado no sentido de uma reduçáo do envolvimento hospitalar - redução do número de camas hospitalares, redução da permanência média em internamentos hospitalares - pode levar ainda, e tem levado, a uma maior procura de cuidados primários de saúde (UEMO, 2002) e da própria medicina interna, duas especialidades de cuidados médicos muito próximas daquelas de que nos ocupamos.

No contexto europeu (particularmente relevante para a análise do caso português) os cuidados continuados têm sido objecto de tratamento privilegiado, desde, pelo menos o Conselho Europeu de Lisboa de Março de 2000 que assinalou a necessidade de reformar os sistemas de protecçáo social. Em Dezembro de 2001 uma Comunicaçáo da Comissão Europeia "O Futuro da Assistência de Saúde e dos Cuidados às Pessoas Idosas: Garantir a Acessibilidade, a Qualidade e a Sustentabilidade Financeira” veio desafiar os sistemas de assistência de saúde e os cuidados de longa duração a garantir o acesso universal independentemente dos rendimentos e dos bens pessoais, um alto nível na qualidade da assistência e a respectiva sustentabilidade financeira. Reconhecia-se que estes objectivos dependiam da taxa de envelhecimento da população e das evoluçôes sociais e tecnológicas, referindo entre estas: as novas tecnologias e terapêuticas, a melhoria do bem estar e da informação ao doente e o envelhecimento da populaçáo (necessidade de promover um envelhecimento activo).

A Comunicação da Comissão Europeia "Modernizar a Protecção Social para o Desenvolvimento de Cuidados de Saúde e de Longa Duração com Elevada Qualidade, Acessíveis e Sustentáveis: Apoio às Estratégias Nacionais Usando o Método Aberto de Coordenação" reconhece que a protecção social é um meio de distribuir, ao nível da sociedade no seu todo, os custos que muitas vezes excedem os recursos de um indivíduo ou de uma família, garantindo que o pagamento dos cuidados de saúde náo conduza ao seu empobrecimento e que mesmo aqueles que tenham rendimentos mais baixos possam aceder aos cuidados. Para além disso reconhece a necessidade de "envolver e atribuir responsabilidades a todos os actores que participam no sistema de cuidados - incluindo parceiros sociais, as autoridades regionais e locais, os doentes e a sociedade civil - e coordenar os prestadores de cuidados, as organizaçôes financeiras, as ONG`s e as autoridades públicas” (EC, 2004). Tendo isto em conta a Comunicação propóe uma série de objectivos conjuntos a satisfazer pelos Estados Membros dentre os quais se incluem os seguintes:

- oferecer a toda a população cuidados de elevada qualidade adaptados às suas necessidades

- oferecer cuidados específicos para a população idosa baseados numa coordenaçáo entre os serviços sociais, os prestadores de cuidados primários, os serviços hospitalares e as instituições especializadas;

- promover cuidados paliativos e terminais

- reduzir, onde necessário, as desigualdades regionais na prestação de cuidados;

- desenvolver, onde necessário, estruturas adequadas com pessoal treinado para aumentar a oferta de cuidados e reduzir as listas de espera;

- promover cuidados de elevada qualidade para melhorar o estado de saúde das pessoas e a qualidade de vida; 
- assegurar um nível elevado de formação básica e contínua dos trabalhadores dos cuidados de saúde;

- definir os direitos dos doentes e das suas famílias e os modos de participação da sociedade civil organizada;

- assegurar a existência de fundos públicos suficientes e a sua disponibilidade para satisfazer as necessidades do sistema de cuidados;

- melhorar a eficácia do sistema, baseado na descentralização, através do envolvimento dos vários actores (autoridades públicas locais e regionais, instituiçóes da segurança social e outros financiadores, os profissionais de saúde e hospitais e os doentes), tornando-os responsáveis pela gestáo dos recursos e pela prestação dos cuidados (EC 2004).

Em síntese, existe hoje por parte das instituiçóes da União Europeia uma clara prioridade atribuída aos cuidados continuados e um esforço para envolver os Estados Membros na construção de sistemas de cuidados de acesso universal equitativos e solidários. E, de acordo com o que se expressa no ponto imediatamente anterior, o modelo de gestão preferido não é mais o da provisão pública exclusiva mas sim o de uma gestão em parceria envolvendo instituiçóes públicas e privadas, profissionais e famílias. Fica aberto, em cada Estado, a configuração específica que assume este modelo e, particularmente, a extensão dos poderes conferidos a cada um dos actores nessa parceria.

\section{Uma diversidade de sistemas. As tipologias de welfare}

A configuração nacional dos modelos não é um produto da livre escolha, antes depende, em grande medida, da própria filosofia e história do sistema de protecção social. É que os Estados Membros têm regimes de protecção muito distintos no que respeita à responsabilidade do Estado na intervenção, no que respeita os modos de financiar as políticas sociais, no que respeita ao universo das pessoas abrangidas pela protecção e no que respeita aos níveis de protecção.

Quanto ao primeiro aspecto, a responsabilidade do Estado nas respostas sociais, os regimes de protecção variam entre uma filosofia mais liberal em que a satisfação das necessidades (e, designadamente, as sociais) é considerada um assunto dos indivíduos e das famílias e o Estado só intervém quando eles sejam de todo incapazes de assegurar as respostas às suas necessidades pelos próprios meios e uma filosofia mais social-democrática em que o Estado reconhece como missão sua assegurar que todos os cidadãos possam fruir gratuitamente de um certo nível de satisfação das necessidades sociais ou de bem-estar social. No primeiro caso, entende-se que a fonte normal de satisfação das necessidades é o mercado e que os indivíduos acedem a ele mediante os rendimentos obtidos pelo trabalho. No segundo, entende-se que no pacto social fundador da democracia a sociedade civil delega no Estado importantes funções de provisão social pautadas pelo universalismo e por um certo nível de redistribuição social da riqueza para que todos possam viver com um mínimo de dignidade.

Deste ponto de vista, o Estado português, à luz da Constituição da República, tem um mandato de tipo social-democrático (cfr. arts $1^{\circ}$ e $2^{\circ}$ da CRP e todo o Título II da mesma CRP sobre "Direitos e Deveres Económicos, Sociais e Culturais"). Porém, à luz da prática política e governativa que se instaurou quase desde a entrada em vigor da Constituição, é duvidoso que a extensão e a intensidade da acção do Estado correspondam a esse modelo. É que, apesar de a norma constitucional parecer configurar verdadeiros direitos subjectivos 
públicos à ajuda do Estado (Canotilho e Moreira, 2007: 814), a verdade é que o legislador ordinário tem tido um entendimento muito estrito acerca do que aos poderes públicos cabe garantir e uma boa parte dos preceitos constitucionais náo passam de meras normas programáticas sem conteúdo plasmado em legislação social de tipo universalista.

E isto tem a ver com o carácter recente do providencialismo estatal e com uma deficiente cultura de cidadania social entre nós - o que, aliás, é comum a outros países. Assim, quando se comparam as políticas sociais dos países do Sul da Europa, as semelhanças entre elas nestes domínios são flagrantes e apontam para o que já se tem designado de "síndrome do sul", caracterizado pela falta de determinação (sofness) do Estado, pelo pluralismo assistencial, pelos particularismos e clientelismo institucional, pela promiscuidade público-privado, pelo peso da doutrina social da Igreja, etc. (Leibfried e Pierson, 1992; Ferrera, 1996; Rhodes, 1996).

Autores como Esping-Andersen (1990) chamaram a nossa atenção para o facto de em nenhuma parte o Estado assumir isolado a satisfação das necessidades sociais básicas dos cidadão. A responsabilidade do Estado antes se combina, em diferentes proporçôes, com a responsabilidade da família e das instituiçóes da sociedade civil. $\mathrm{O}$ mercado rege-se por regras económicas que não asseguram a produção de bens e serviços sociais a preço acessível a toda população e, por isso, o Estado e as instituições da sociedade civil, incluindo as redes primárias de solidariedade baseadas no parentesco, na vizinhança e na amizade, são chamados a intervir em modalidades e com uma participação muito diversa.

O que importa reconhecer, no caso português (tal como na generalidade dos países do sul da Europa), é que a história de intervenção do Estado neste domínio específico dos cuidados aos cidadãos dependentes é muito recente, rompendo com a tradição de caber às familias e às comunidades (no caso destas, às organizações formais de solidariedade misericórdias, centros paroquiais, associações cívicas, etc) a obrigação de cuidar dos seus membros dependentes (Hespanha et al. 2000). Até agora, esta responsabilidade assumida pela própria "sociedade-providência" tem poupado ao Estado desempenhar o papel que os preceitos constitucionais lhe conferem neste domínio (tal como em vários outros). Contudo, a alteração progressiva e irreversível das condiçóes (família extensa, reduzida esperança de vida, divisão sexual do trabalho, fraca mobilidade, etc.) de que as famílias e as comunidades dispunham para cuidar dos seus veio a tornar dramática e insuportável a situação de abandono dos cidadãos dependentes ou a situação de sobrecarga dos familiares que cuidam desses cidadãos (Hespanha e Portugal, 2002).

Por isso o problema entra estridente na agenda política e obriga os governos a agir. Esta assunção da responsabilidade do Estado náo implica necessariamente que seja o Estado a prestar directamente os cuidados necessários através de instituiçóes próprias, tal como acontecera nos exemplos históricos de sociedades que construiram um Estado-Providência de tipo social-democrático. A existência de inúmeras instituições de solidariedade social, disseminadas pelo território, torna possível contratualizar a prestação dos cuidados com essas instituiçóes assumindo o Estado o papel de mero coordenador, fiscalizador ou regulador $^{2}$. Neste modelo torna-se essencial avaliar o modo como o Estado e as instituiçốes desempenham os seus papéis e a capacidade de resposta do próprio modelo.

\footnotetext{
2 Segundo a CRP ( $\operatorname{art}^{\circ}$ 63.5) ao Estado cabe apoiar e fiscalizar a actividade e funcionamento das instituiçóes particulares de solidariedade social ou outras, com vista à realizaçáo dos objectivos do $\operatorname{art}^{\circ}$ 67.2. ou seja, "promover a criação e garantir o acesso a uma rede nacional (..) de equipamentos sociais de apoio à família” (arto 67.2.b).
} 
Quanto ao segundo aspecto - modos de financiar a protecção social - também os Estados seguem diferentes sistemas. Os dois principais sistemas mais usados são o do financiamento através dos impostos e o do financiamento através das contribuiçóes dos trabalhadores para o seguro obrigatório. No primeiro caso, todos os cidadãos contribuintes pagam; no segundo apenas os cidadãos que trabalham pagam para o sistema. Mas existem outros efeitos que decorrem da diferente filosofia dos sistemas. O sistema de financiamento através dos impostos permite ao Estado afectar as receitas de acordo com as prioridades nacionais, permitindo inclusive corrigir algumas distorções decorrentes da desigual distribuição da riqueza na sociedade. Já o sistema de financiamento pelas contribuições limita a função redistributiva das políticas, tornando a protecção que cada cidadão recebe directamente dependente dos montantes por si descontados. Por isso este sistema tem sido qualificado de corporativo, ou seja, cada grupo profissional tem o seu regime próprio de protecção. Porém, o financiamento não se esgota nestas duas fontes. Em muitos casos, o acesso aos bens e serviços depende do pagamento de uma contrapartida financeira por parte do utilizador. Aqui podemos encontrar as situaçóes mais diversas: desde as taxas moderadoras que se destinam apenas a desincentivar a procura banal de serviços, até às taxas de utilização de serviços que correspondem a um pagamento dos custos estimados do serviço recebido ${ }^{3}$. Em sociedades de menores recursos com a portuguesa, a tentação dos governos é de introduzir sistemas de retribuição dos custos dos serviços eventualmente modelada pelos rendimentos dos cidadãos utentes, o que na linguagem de Esping-Andersen corresponde a um processo de re-mercadorização oposto ao de processo de desmercadorização que caracterizou os Estados-Providência social-democráticos.

O terceiro aspecto a reter é o do universo das pessoas abrangidas pelas políticas de protecção social. Aqui, existem dois sistemas polares: o sistema assistencialista que reserva apenas a protecção para aquelas pessoas que não tenham recursos suficientes, através de um regime de prova de insuficiência meios; e, no outro extremo, o sistema universalista que generaliza a protecção a toda a população que necessite de protecção, independentemente dos seus recursos. Em termos dos regimes de welfare tipificados por Esping-Andersen, o Estado-Providência social-democrático corresponde à filosofia universalista, enquanto que o Estado-Providência liberal corresponde à filosofia assistencialista. A tendência das reformas do Estado-Providência nas últimas décadas tem ido no sentido da redução da filosofia universalista, tendo as políticas passado a orientar-se preferencialmente para certos grupos-alvo da população (targeting) ou então é introduzido o princípio da discriminação positiva, dando preferência a quem tem menores rendimentos (princípio da selectividade). Os argumentos mais fortes contra esta selectividade invocam o carácter potencialmente estigmatizador das políticas dirigidas exclusivamente a pessoas de menos recursos ${ }^{4}$ e a perda de qualidade e residualização desses serviços dada a menor capacidade reinvindicativa dos seus utilizadores.

\footnotetext{
${ }^{3}$ Como não funcionam as regras de mercado para a formação dos preços, os custos têm de ser estimados e, tradicionalmente, esses custos eram estimados de uma forma que os tornava bem mais baixos do que os preços de mercado para serviços equivalentes. Uma das diferenças notórias na estimativa dos custos dos serviços públicos foi a sua aproximação ao de uma avaliação analítica dos custos de produção dos bens de mercado.

4 Veja-se o argumento usado pelos defensores do "rendimento básico" ou "de cidadania" contra o modelo de "rendimento mínimo garantido" ou outro similar para pessoas muito pobres (van Parijs, 2000).
} 
Finalmente, os níveis de protecção social. Os níveis de protecção do Estado têm a ver, fundamentalmente, com dois factores: a filosofia mais liberal ou mais social-democrática do Estado-Providência e o nível de recursos financeiros para afectar às políticas sociais. Um razoável indicador de performance neste domínio é a percentagem do produto nacional afecta às políticas sociais. Em 2003 a percentagem do PIB dos 15 países membros da UE afecta à despesa social era de $28,3 \%$, variando entre os $33,5 \%$ da Suécia e os $24,3 \%$ de Portugal (EUROSTAT, 2006). O padrão de repartição da despesa entre as várias funçóes é bastante desigual e varia significativamente de país para país. Em 2003 esse padrão era o seguinte para os 15 e para Portugal: a) cuidados de saúde - UE15 28,4\%, Portugal 28,8\%; b) deficiência - UE15 7,9\%, Portugal 11,5\%; c) velhice - UE15 40,9\%, Portugal 39,3\%; d) sobrevivência - UE15 4,6\%, Portugal 6,9\%; e) família e criança - UE15 8,0\%, Portugal 6,5\%; f) desemprego - UE15 6,7\%, Portugal 5,5\%; g) alojamento - UE15 2,0\%, Portugal $0,0 \%$; e h) pobreza/exclusão social - UE15 1,5\%, Portugal 1,5\% (ibid.). É notória a concentração da despesa social nas pensóes (velhice, deficiência e sobrevivência) e nos cuidados de saúde e, em particular em Portugal, onde atingem os $86,5 \%$ da despesa social total.

\section{Os cuidados continuados em Portugal}

Para além do que já ficou dito acima sobre as particularidades do modelo social português - e que se torna relevante para apreciar os programas específicos como os dos cuidados continuados -, convém ter igualmente em conta que o curso das políticas sociais e das reformas parece estar a ser influenciado, em grande medida, pelos padrôes de decisão política da União Europeia e por certos programas sociais adoptados por vários países membros que se tornaram modelares 5 .

A condição europeia de Portugal influenciou ainda as nossas políticas sociais por outras formas dignas de consideração. Primeiro, pela via dos fundos estruturais (principalmente do FSE) e de coesão (Programas Delors I e II), os quais se tornaram decisivos para o lançamento de programas em muitas áreas do social (emprego, formação profissional, saúde, educação, habitação e pobreza). Segundo, pela via do pacto de estabilidade e crescimento, associado ao sistema monetário europeu, que tornou o argumento da convergência em fundamento indiscutível para a retracção das políticas públicas, traduzida em cortes da despesa pública, no estrangulamento da segurança social, no congelamento dos salários e das prestaçōes sociais, na privatização, redução ou encerramento dos serviços publicos, tudo isto com consequências incontornáveis para o aumento da vulnerabilidade à exclusão e para o agravamento das desigualdades.

Portugal, tal como os outros países do sul da Europa, tem um sector de cuidados médicos e sociais continuados pouco desenvolvido. Trata-se de um domínio até há pouco tempo considerado da responsabilidade das famílias, mas que, mercê das mudanças ocorridas na estrutura e composição das famílias e da entrada massiva da população feminina no merca-

\footnotetext{
5 A Resolução do Conselho de Ministros no 59/2002 que cria o Programa Rede Mais para a protecção das pessoas com elevado grau de dependência (vd. infra) refere, a propósito, o papel do Comité de Protecção Social da Uniāo Europeia na definiçáo dos objectivos e na orientação e preparação das agendas do Conselho Europeu nesta matéria.
} 
do de trabalho, tem vindo a ser alvo da atenção crescente do Estado e das instituições não governamentais.

Um dos principais problemas que uma política de cuidados continuados tem de enfrentar é a da condição pobre da população dependente. Desde logo a dos idosos e, em particular, a dos idosos vivendo de uma pensão de reforma. De acordo com a informação estatística disponível, a condiçáo de reformado revela um risco de pobreza bastante mais elevado que o dos indivíduos que estâo a trabalhar, respectivamente $23 \%$ contra $11 \%$, em $2006^{6}$. Em 2001, a distribuição do rendimento monetário equivalente médio dos mesmos apresentava níveis inferiores aos da população portuguesa, ainda que se tenha sentido, entre 1995 e 2001, uma melhoria da situação monetária das pessoas idosas de mais baixos rendimentos e dos de classe média de rendimentos. Cerca de 66\% tinham rendimentos mensais inferiores à média nacional. Apesar da melhoria sustentada assegurada pelo sistema de segurança social, em particular, do sistema de pensóes, desde a segunda metade da década de 90, prevalecem situaçóes extremamente vulneráveis de idosos que vivem de pensóes com valores muito baixos (PNAI, 2006: 12). Então a pressão para que estes casos de dependência sejam suportados pelo sistema é muito forte e crescente, na medida em que o acesso ao mercado de cuidados esbarra com preços proibitivos e que a família cada vez menos dispóe de condiçôes para o acolhimento ${ }^{7}$.

Os apoios públicos de carácter assistencial em Portugal sempre tiveram um carácter esporádico e destinaram-se a resolver as dificuldades mais dramáticas. $\mathrm{O}$ único apoio assinalável para os casos em que a família não dispunha de meios para sobreviver tinha origem nas organizações da sociedade civil, em particular as de cunho confessional, mas importa reconhecer que esse apoio raramente tinha consistência, cobertura adequada ou qualidade técnica.

Por isso, a história dos cuidados continuados às pessoas dependentes não regista nenhum papel relevante do Estado ou das instituiçóes públicas. As poucas iniciativas institucionais que podem ser mencionadas cabem sobretudo às instituiçóes da Igreja e, dentre estas, às misericórdias. Nos últimos cem anos os apoios públicos de carácter assistencial - esporádicos e para resolver dificuldades pontuais mais dramáticas - eram concedidos directamente às famílias sem qualquer garantia de continuidade (Hespanha, 1998; Rodrigues, 1999).

O programa da Rede Nacional de Cuidados Continuados Integrados criado em 2006 vem preencher essa lacuna do sistema de protecção social português. Ele surge com a progressiva consciencialização da impotência dos dependentes e suas famílias, da falta de resposta das instituçóes da sociedade civil e da existência de uma pressão crescente sobre o Estado para que responda aos problemas graves de dependência com medidas articuladas de apoios médicos e sociais.

\subsection{Antecedentes}

Esta consciência foi-se traduzindo, no último quartel do séc. XX, no surgimento de respostas pontuais ou pouco estruturadas tanto públicas quanto privadas solidárias, num

${ }^{6}$ A taxa de risco de pobreza sobe dramaticamente para os $40 \%$ quando se trata de um idoso vivendo sozinho (EUROSTAT, 2007).

7 A proporçáo de idosos maiores de 65 anos internados nas unidades da RNCCI era de 80,2\% ao fim do primeiro ano de funcionamento do Programa (RNCCI, 2007:19). 
processo misto de desenvolvimento do Estado-Providência e de multiplicação e diversificação das organizaçôes não governamentais quase sempre sob a égide do Estado. Vale a pena esquissar a evolução dessas respostas de cuja experiência beneficiou o programa RNCCI.

A primeira referência vai para o Programa de Apoio Integrado a Idosos (PAII) criado em 1994 e que se destinava a ser promovido pelas organizaçóes não governamentais de base local ${ }^{8}$. Ele caracterizou-se por um conjunto de medidas inovadoras que visavam contribuir para a melhoria da qualidade de vida das pessoas idosas, prioritariamente no domicílio e no seu meio habitual de vida, desenvolvendo-se através de projectos de desenvolvimento central e a nível local.

De entre os objectivos do PAII incluiam-se: a promoção da autonomia das pessoas idosas e/ou pessoas com dependência, prioritariamente no seu meio habitual de vida; o estabelecimento de medidas para melhorar a mobilidade e acessibilidade a serviços; a implementação de respostas de apoio às famílias que prestem cuidados a pessoas com dependência, especialmente idosos; a promoção e apoio à formação de prestadores de cuidados informais e formais, de profissionais, familiares, voluntários e outras pessoas da comunidade; e o desenvolvimento de medidas preventivas do isolamento e da exclusão.

O Programa visava ainda contribuir para a solidariedade entre as geraçóes, para uma sociedade aberta a todas as idades, para o desenvolvimento de respostas inovadoras e integradas (no âmbito da saúde e da acção social), para a promoção de parcerias e para a criação de postos de trabalho.

A promoção das iniciativas devia ser assegurada pelas IPSS e Misericórdias e integrar as instituiçóes de saúde e da segurança social dos locais onde se desenvolviam os programas como parceiros activos. A gestão e monitorização dos projectos cabia a uma Comissão de Gestão, sedeada em Lisboa e o acompanhamento a nível local era realizado pelas mesmas instituiçóes que integravam a parceria responsável pela execução do projecto. Esta duplicidade de estatuto/funçóes veio a gerar constrangimentos e provocar um olhar pouco crítico sobre o andamento dos projectos. A própria cultura de parceria, não estando interiorizada, levou a que as pessoas não trabalhassem como parceiros mas sim como representantes das instituições.

Por seu turno, a cobertura territorial do Programa foi muito limitada e a continuidade no tempo não foi assegurada porquanto se tratava, quase sempre, de iniciativas experimentais. O financiamento para estes projectos durava em média dois anos, cessando depois a responsabilidade do Estado, o que tornou difícil às instituiçóes darem continuidade aos projectos e assegurarem a sua sustentabilidade financeira.

No entanto, estes Projectos foram importantes por terem permitido desenvolver acçôes inovadoras dirigidas à população idosa e, simultaneamente, por terem dinamizado parcerias locais. Algumas dessas acçóes representaram ganhos significativos para a populaçáo-alvo, como o alargamento do apoio domiciliário às vinte e quatro horas, incluindo os fins-de-semana, a melhoria da qualidade dos cuidados de saúde e de apoio social prestados, o apoio à formação das famílias, o investimento na criação de internamento temporário com reabilitação, a facilidade do acesso a ajudas técnicas, a melhor articulação com o pro-

8 Despacho Conjunto, de 1 de Julho de 1994, dos Ministros da Saúde e do Emprego e da Segurança Social e reiterado por despacho, em 4 de Julho de 1996, da Ministra da Saúde e do Ministro da Segurança Social e do Trabalho. 
cesso de preparação de altas hospitalares e institucionais e, ainda, o incentivo à eliminação de barreiras arquitectónicas nos domicílios das pessoas idosas abrangidas.

Em 1998, por iniciativa conjunta dos Ministérios da Saúde e do Trabalho e Solidariedade foram aprovadas orientaçóes gerais para regular a intervenção de uma forma articulada do apoio social e dos cuidados de saúde continuados dirigidos a pessoas em situação de dependência'. Dos diferentes tipos de respostas anunciadas, as mais procuradas foram as Unidades de Apoio Integrado (UAI) e o Apoio Domiciliário Integrado (ADI). Enquanto as UAI eram pensadas como algo surgindo das estruturas ou serviços já existentes (ou na sua proximidade), de pequena dimensão, em articulação com os serviços de saúde e de assistência social e em íntima ligação com as famílias, dando-lhes apoio e também formação, o ADI é pensado como a resposta prioritária e charneira, no sentido em que lhes cabe resolver as situações menos exigentes do ponto de vista da especialização dos cuidados e monitorizar as situações que possam evoluir para níveis de exigência mais elevados.

Umas e outras demonstraram ser possível um caminho de experimentação, no terreno, de formas organizativas de prestaçáo de cuidados continuados integrados e a experiência recolhida foi decisiva para fazer avançar uma política mais estruturada neste domínio.

Assim, em Fevereiro de 2002, foi publicada uma resolução do Governo que cria um sistema de Cuidados Continuados Integrados - designado Rede Mais ${ }^{10}$ - que viria a influenciar decisivamente o sistema actualmente em vigor. Considerando que a protecção social das pessoas com elevado grau de dependência constituia uma prioridade e devia ser tomada a cargo pelo Estado, este Programa visava instituir uma política de cuidados continuados integrados e criar uma rede de respostas organizadas de saúde e de apoio social integrando as duas dimensóes consideradas indissociáveis, a da solidariedade e segurança social e a da saúde.

O objectivo desta Rede era "garantir uma protecção social integrada, financeiramente sustentável, com base numa tipologia de respostas mais bem adaptadas às necessidades das pessoas em situação de dependência, ou em risco de nela entrarem, estruturada em redes locais que envolvam transversalmente estruturas públicas e privadas e que hão-de impulsionar a organização, a nível regional e nacional, de redes cada vez mais alargadas. Esta protecção social exige uma continuidade de cuidados em diferentes localizaçôes geográficas, assegurados por profissionais com formação diferenciada e ajustados aos problemas identificados, por forma a maximizar a sua eficiência e eficácia e a facilitar o respectivo acesso aos que deles necessitam”.

A queda do governo, pouco depois da aprovação do Programa Rede Mais e a constituição de um novo governo de coligação centro-direita vieram comprometer a execução deste Programa até ao mandato seguinte do Partido Socialista.

Entretanto, o XV Governo institui uma rede de cuidados continuados de saúde, através do Decreto-Lei n. ${ }^{\circ}$ 281/2003, de 8 de Novembro, que se aproxima da do governo socialista

9 Despacho Conjunto dos Ministros da Saúde e do Trabalho e da Solidariedade, número 407/98, de 15 de Maio,

10 Resolução do Conselho de Ministros n. ${ }^{\circ}$ 59/2002 revogada pelo artigo 30. ${ }^{\circ}$ do Decreto-Lei n. ${ }^{\circ}$ 60/2003 de 1 de Abril. 
mas que limita os cuidados ao campo da saúde (isto é, que não integra a segurança social) e coloca as instituiçóes de apoio social na dependência dos hospitais e centros de saúde ${ }^{11}$.

Regressado ao governo, o Partido Socialista recuperou o seu projecto anterior de cuidados continuados e integrados, incluindo expressamente no Programa de Governo de 2005 a criação de serviços comunitários de proximidade (SCP), a articulação de centros de saúde, hospitais e instituiçóes de apoio social para a prestaçáo de cuidados continuados, a reabilitação imediata do paciente crónico e idoso logo após o episódio agudo e sua reinserção na família, o planeamento dos equipamentos de cuidados continuados, a reactivação dos cuidados de saúde no domicílio e o reforço do apoio à família, através de internamentos temporários e prolongados, apoio domiciliário de saúde e recurso a call centers.

\subsection{A Rede Nacional de Cuidados Continuados Integrados ${ }^{12}$}

Este Programa visa a criação de uma rede de cuidados continuados, constituída por entidades públicas, sociais e privadas, nos domínios da saúde e da segurança social, destinada "a promover, restaurar e manter a qualidade de vida, o bem-estar e o conforto dos cidadãos necessitados dos mesmos em consequência de doença crónica ou degenerativa, ou por qualquer outra razão física ou psicológica susceptível de causar a sua limitação funcional ou dependência de outrem, incluindo o recurso a todos os meios técnicos e humanos adequados ao alívio da dor e do sofrimento, a minorar a angústia e a dignificar o período terminal da vida" (Decreto-Lei no 101/2006, de 6/6)

Para este Programa os cuidados continuados integrados definem-se como "o conjunto de intervençôes sequenciais de saúde e ou de apoio social, decorrente de avaliação conjunta, centrado na recuperação global entendida como o processo terapêutico e de apoio social, activo e contínuo, que visa promover a autonomia melhorando a funcionalidade da pessoa em situação de dependência, através da sua reabilitação, readaptação e reinserção familiar e social" ( $\left.\operatorname{art}^{\circ} 3^{\circ}, a\right)$. E a situação de dependência é definida como aquela "em que se encontra a pessoa que, por falta ou perda de autonomia física, psíquica ou intelectual, resultante ou agravada por doença crónica, demência orgânica, sequelas pós-traumáticas, deficiência, doença severa e ou incurável em fase avançada, ausência ou escassez de apoio familiar ou de outra natureza, não consegue, por si só, realizar as actividades da vida diária” ( $\left.\operatorname{art}^{\circ} 3^{\circ}, h\right)$ ).

O Programa define as situaçôes que têm acesso à Rede: $a$ ) dependência funcional transitória decorrente de processo de convalescença ou outro; $b$ ) dependência funcional prolongada; $c$ ) dependência de pessoas idosas com critérios de fragilidade; $d$ ) incapacidade grave, com forte impacte psicossocial; $e$ ) e doença severa, em fase avançada ou terminal ( $\left.\operatorname{art}^{\circ} 31^{\circ}\right)$.

A definição dos objectivos a atingir pelo sistema é muito ampla e engloba, a prestação de cuidados continuados de saúde e ou de apoio social a dependentes, de qualquer idade; cuidados terapêuticos e apoio social no domicílio destinado a pessoas com perda de funcionalidade ou em risco de a perder; progressiva cobertura a nível nacional, das necessidades das pessoas em situaçáo de dependência em matéria de cuidados continuados integrados e de cuidados paliativos, apoio aos familiares ou prestadores informais, na respectiva qua-

11 "O acesso à rede é determinado pelo hospital onde o utilizador se encontra internado ou pelo centro de saúde da sua área geográfica” ( $\left.\operatorname{art}^{\circ} 8^{\circ}, 1\right)$.

12 Cfr. o site desta Rede em http://www.rncci.min-saude.pt/RNCCI/. 
lificação e na prestação dos cuidados; articulação e coordenação em rede dos cuidados em diferentes serviços, sectores e níveis de diferenciação.

Do ponto de vista orgânico, a Rede situa-se a um nível intermédio de cuidados de saúde e de apoio social, entre os de base comunitária e os de internamento hospitalar. E do ponto de vista funcional, ela assenta numa tipologia de serviços constituida por quatro categorias: 1. as Unidades de Internamento (compreendendo Unidades de Convalescença UC, Unidades de Média Duração e Reabilitação - UMDR, Unidades de Longa Duração e Manutenção - ULDM, e Unidades de Cuidados Paliativos - UCP), 2. as Unidades de Ambulatório, correspondentes a Unidades de Dia e de Promoção da Autonomia Psicossocial, por situaçáo clínica decorrente de recuperação, 3. as Equipas Hospitalares (compreendendo as de Equipas de Gestão de Altas e as Equipas Intra-hospitalares de Suporte em Cuidados Paliativos) e 4. as Equipas Domiciliárias (compreendendo as Equipas de Cuidados Continuados Integrados e as Equipas Comunitárias de Suporte em Cuidados Paliativos).

Esta amplitude elevada de objectivos não se traduz na oferta imediata de serviços correspondentes mas sim na construção progressiva de um sistema nacional de cuidados que lhes possa dar resposta no futuro ( $\left.\operatorname{art}^{\circ} 4,2, \mathrm{~g}\right)$ ) e que se estima esteja implantado plenamente em 2016. Devida à opção pela complementaridade do papel do Estado, a edificação e consolidação do sistema fica dependente, entre outros factores, da disponibilidade de recursos, da articulação das respostas públicas e do dinamismo da sociedade civil. O programa teve um primeiro período inicial de um ano de carácter experimental em que se investiu principalmente nas unidades de internamento, através da contratualização de respostas com o sector privado não lucrativo (maxime, Misericórdias e Instituições Particulares de Solidariedade Social $)^{13}$

Se bem que o Programa vise a resposta às situaçóes mais dramáticas de dependência, a verdade é que este objectivo se combina com outros objectivos de natureza distinta. O mais óbvio é o do descongestionamento das unidades hospitalares de casos que exigem cuidados pouco diferenciados e tem a ver sobretudo com objectivos de gestáo económica dos recursos ${ }^{14}$. Em muitas situaçôes as altas hospitalares são adiadas pelo reconhecimento da incapacidade de os doentes e as suas familias suportarem os cuidados continuados após a alta hospitalar. Esta é a situação que manifestamente justifica a criação de unidades de convalescença, mas o mesmo motivo pode estar presente na criação das restantes unidades de internamento previstas pelo Programa. Em que medida os dois objectivos se conjugam ou conflituam é uma questão empírica que só poderá ser respondida a partir da experiência de execução do Programa. A situação crítica será aquela em que o doente permanece internado no hospital não apresentando justificaçáo clínica para isso, mas apenas social: o facto de não ter condiçóes para ser cuidado no domicílio. Do ponto de vista do hospital este internamento implica uma despesa evitável e ocupa uma cama que pode ser necessária para

13 No termo do período experimental, as taxas de cobertura por referência à população com idade igual ou superior a 65 anos era ainda muito baixa: de 20 camas por 100.000 habitantes para as UC, de 14 camas por 100.000 habitantes para as UMDR, de 40 camas por 100.000 habitantes para as ULDM e de 1 cama por 100.000 habitantes para as UCP (RNCCI, 2007). As metas para 2016, altura em que o Programa fica plenamente executado, são respectivamente 144/100.000 (UC); 160/100.00 (UMDR); 400/100.000 (ULDM) e 48/100.000 (UCP) (RNCCI, 2006).

14 No período experimental, mais de dois terços dos doentes internados em unidades do RNCCI eram provenientes de hospitais (RNCCI, 2007:19). 
outro doente. As unidades de internamento de longa duração serão porventura aquelas mais procuradas nestes casos.

Uma análise crítica do Programa obriga a salientar quatro aspectos que lhe dão especificidade e que, ao mesmo tempo, suscitam particulares problemas ao seu desenvolvimento: primeiro, trata-se de uma parceria entre o Estado e as instituiçôes e não de um serviço criado e mantido exclusivamente pelo Estado; segundo, sendo uma rede institucional de parceiros, a soluçáo encontrada defronta-se com problemas de governaçáo muito particulares; terceiro, abrange cuidados de saúde a par de cuidados sociais; quarto, a família constitui um dos elementos chave deste sistema.

Analisemos, em maior detalhe, estes quatro aspectos.

\section{1. um sistema público baseado em parcerias}

A rede de parceiros é vasta e integra entidades públicas (hospitais, centros de saúde, serviços locais e distritais da segurança social), instituiçóes privadas de solidariedade social (misericórdias, IPSS e pessoas colectivas de utilidade pública administrativa) e autarquias locais e, do ponto de vista organizativo, opera a um plano regional e a um plano local $\left(\operatorname{art}^{\mathrm{o}} 2^{\circ}\right)$.

No entanto, a coordenação cabe a uma estrutura nacional dependente, nas suas competências e composição, dos dois ministros da tutela, cabendo-lhe genericamente "promover a articulaçáo com os parceiros que integram a Rede". Existe também coordenação aos níveis regional e local: coordenação regional a cargo de representantes das ARS e CDSS (ECR); coordenação local a cargo de equipas concelhias (ECL) formadas por representantes das mesmas instituiçôes públicas ${ }^{15}\left(\operatorname{art}^{\circ} 9^{\circ}\right)$. Porém esta coordenação aos níveis sub-nacionais é meramente consultiva, no sentido em que as ECR e as ECL não têm qualquer autonomia deliberativa. Nota comum e geral é a de as tarefas de coordenação caberem a representantes das instituiçốes públicas da saúde e da segurança social.

Do ponto de vista operacional, é a parceria a nível local (entre as instituições locais de saúde, de segurança social e outras comunitárias) quem cria a estrutura orgânica destinada a prestar cuidados continuados integrados, o "serviço comunitário de proximidade" (SCP), o qual deve integrar unidades de saúde familiares (USF) ${ }^{16}$.

Decisóes importantes, como a de fazer ingressar as pessoas na Rede, cabe em regra às equipas coordenadoras locais mediante proposta de diferentes entidades consoante as situaçôes de dependência.

- no caso de doentes internados nos hospitais que necessitem de acompanhamento após alta, a proposta cabe às equipas de gestão de altas ${ }^{17}$, sediadas em hospitais de agudos e constituídas, no mínimo, por um médico, um enfermeiro e um assistente social;

- no caso de cuidados paliativos, a proposta cabe às equipas intra-hospitalares de suporte em cuidados paliativos sediadas em hospitais de agudos e constituídas, no mínimo, por um médico, um enfermeiro e um psicólogo;

15 E, eventualmente, um representante da autarquia.

16 Enquanto as USF não existirem, o SCP é constituído pelo Centro de Saúde, pelos serviços locais de Segurança Social, pelas autarquias locais e por outros serviços públicos, sociais e privados de apoio comunitário que a ele aderirem $\left(\operatorname{art}^{\circ} 3^{\circ}\right.$, al. $\left.\left.\mathrm{n}\right)\right)$.

17 Em articulação com as equipas terapêuticas hospitalares, as equipas coordenadores da Rede e as equipas prestadoras de cuidados continuados integrados dos Centros de Saúde ( $\operatorname{art}^{\circ} 24^{\circ}$ ). 
- no caso de pessoas dependentes cuja situação náo requer internamento, a proposta cabe às equipas de cuidados continuados integrados da responsabilidade dos cuidados de saúde primários e das entidades de apoio social para a prestação de serviços domiciliários ${ }^{18}$.

Sabe-se como, em regra, tendem a existir problemas de cooperação interinstitucional no seio das parcerias: ou porque os parceiros têm falta de tradição em cooperar entre si ou porque estão dotados de poderes muito desiguais no contexto da sociedade local, ou por outras razóes (Sousa et al., 2007). Os parceiros com maior conhecimento ou implantação no meio, com mais prestígio ou com maior legitimidade social, dificilmente aceitam perder a margem de autonomia de que dispóem e tendem a dominar e a impor os seus interesses próprios. Mas existem outros obstáculos ao diálogo, negociação e tomada colectiva de decisôes: a desconfiança, a autocracia, a inflexibilidade e intolerância, o radicalismo e a busca do conflito em vez de busca do consenso.

No caso presente, dificuldades dos dois tipos podem advir. Por um lado, entre as instituiçóes públicas da saúde e da segurança social que, salvo num curto período de tempo ${ }^{19}$, sempre estiveram dependentes de ministérios distintos apesar da proximidade dos problemas que a cada uma compete resolver relativamente a certas categorias da populaçáo, como é o caso das pessoas idosas ou dependentes. Uma deficiente cultura de cooperação a par de uma arreigada autonomia de acção, um complexo e pouco claro sistema de repartição de responsabilidades (designadamente, financeiras) e um momento crítico de reestruturação dos serviços contribuem ou podem contribuir para limitar uma cooperação eficiente ${ }^{20}$. Por outro lado, entre estas instituiçóes públicas e as organizaçóes privadas de solidariedade social que compóem os serviços comunitários de proximidade, as dificuldades podem dever-se à diferente capacidade de decisão com que estão investidas e ao papel ambíguo - ao mesmo tempo de cooperação e de fiscalização - que desempenham as primeiras relativamente às segundas.

Há ainda que reconhecer que quando não se verificam os pressupostos básicos para a parceria, ou seja, uma adesão voluntária, uma consciência do papel positivo da rede de parceiros e uma capacidade de participação efectiva, os parceiros podem não se envolver como seria expectável. Por sua vez, as motivaçôes para a participação nem sempre são as pretendidas, nem as mais nobres. Não se pode esquecer que os parceiros têm diferentes interesses, diferentes objectivos institucionais, diferentes sistemas de responsabilização, diferentes valores e diferentes estilos de envolvimento (Sousa et al., 2007).

\section{2. uma rede institucional de âmbito nacional}

A opçáo pela criação de uma rede nacional de cuidados visa, segundo o legislador, promover a distribuição equitativa das respostas a nível territorial. Este objectivo resulta da avaliação das experiências anteriores de apoio do Estado a iniciativas locais de natureza

\footnotetext{
${ }^{18}$ Em articulação com o Centro de Saúde e a entidade que presta apoio social ( $\left.\operatorname{art}^{\circ} 27^{\circ}, 2\right)$.

19 Apenas no V Governo Constitucional (1979-80) a Saúde e a Segurança Social ficaram na dependência da mesma pasta governamental: o Ministério dos Assuntos Sociais.

${ }^{20}$ A repartição dos encargos do sistema no primeiro ano de funcionamento mostra que três quartos da despesa de funcionamento foram imputados à saúde e apenas um quarto à segurança social, sendo que destes últimos parte corresponde a pagamentos suportados pelos utentes com as tipologias MDR e LDM (RNCCI, 2007:10). Por sua vez, as despesas de investimento, cerca de duas vezes e meia superiores às de funcionamento, oneram apenas a saúde.
} 
privada solidária que, sendo muito positivas em termos das populaçóes servidas, colocavam problemas sérios de equidade relativamente a outras populaçóes igualmente carentes e não servidas de resposta. Esta disparidade tornou-se flagrante ao longo das décadas de 80 e 90 em que se multiplicaram os projectos locais de intervenção social neste e em outros domínios, muitos deles beneficiando de financiamento europeu e com carácter experimental, sem nenhuma preocupação ou possibilidade de generalização para fora dos seus limites territoriais. $\mathrm{Na}$ última década a percepçáo das "injustiças” geradas por projectos sociais de âmbito local levou a uma preocupação com a equidade territorial na provisão de serviços sociais. O Programa Rede Social, criado em 1996, sintetiza bem esta preocupação do Estado ao criar um sistema de racionalização e planeamento das acçóes a nível concelhio por forma a evitar lacunas gritantes de protecção e uniformizar critérios de oferta de serviços. Mais recentemente o mesmo Programa viu alargadas estas funçóes de coordenaçáo e planeamento a níveis supra-concelhios e teve de passar a ter em conta a coerência dos critérios concelhios com os objectivos nacionais de acção para a inclusão.

Esta opção por uma rede nacional de cuidados coordenada pelo Estado afastou um modelo alternativo seguido em outros países: o de confiar à iniciativa privada solidária a oferta de cuidados à escala local, limitando-se o Estado a regular os requisitos básicos de abrangência e qualidade a que terão de obedecer os serviços. A maior autonomia das instituições locais é vista, em muitas sociedades, como uma vantagem em termos de ajustamento às necessidades locais e de melhor integração dos serviços na comunidade, mas existe um pressuposto que no caso português pode limitar esta opção: o da fraca maturidade e sustentabilidade das instituiçôes locais. Onde estas instituiçóes sejam débeis e pouco activas, o risco de insucesso é muito elevado.

A opção por serviços de base comunitária é também uma decorrência da filosofia do sistema de protecção social e é frequente em países que seguem o modelo liberal, como é o caso dos Estados Unidos da América, ainda que nestes tenda a prevalecer o sistema de seguros de saúde privados com cobertura de doença continuada.

Uma outra dimensão desta mesma questão tem a ver com um conflito de obrigaçóes que pode ocorrer no seio das instituiçóes locais incluídas na RNCCI. A génese e a lógica de inserção local das instituiçốes torna compreensível que estas se possam determinar por princípios de preferência ou prioridade aos membros da comunidade na oferta de cuidados relativamente a pessoas de fora. Contudo, neste período de implantaçáo do sistema em que a cobertura territorial é ainda incompleta, a Rede obriga as instituiçóes cooperantes a acolher os cidadãos mais prioritários segundo critérios regionais (e até) nacionais e sem consideração da sua origem territorial ${ }^{21}$. Ora, tem havido muitas resistências por parte das instituiçóes em dar prioridade a pessoas de fora ou a prescindir da reserva de um número mínimo de camas para pessoas da terra que venham a precisar, mostrando que a lealdade à comunidade é muito forte mesmo quando confrontada com a lealdade devida ao Estado, representando aqui a comunidade nacional. Trata-se de uma questáo muito sensível que exige um tratamento muito ponderado, pois qualquer postura excessiva pode prejudicar a relação que as instituiçóes têm (ou devem ter) com as suas comunidades. Também, do

${ }^{21} \mathrm{Na}$ definição de princípios a que o sistema deve obedecer, inclui-se o da proximidade de cuidados, através da "potenciação de serviços comunitários de proximidade $\left(\operatorname{art}^{\circ} 6^{\circ}, \mathrm{d}\right)$ ). A formulação do programa Rede Mais era mais explícita quanto à necessidade de "manter o (...) utilizador, sempre que possível, dentro do seu enquadramento comunitário" $\left.\left(\operatorname{art}^{\circ} 4^{\circ}, \mathrm{d}\right)\right)$. 
ponto de vista do apoio familiar, a colocação de pessoas dependentes em instituiçóes de acolhimento longe da sua comunidade de origem levanta sérios problemas de que convém estar consciente e deve ser evitada ou reduzida a uma duração mínima. O financiamento de deslocaçóes regulares de familiares directos é, decerto, uma compensação justa mas é preciso assegurar que essa medida é efectivamente aplicada e que não fica sujeita a condicionamentos burocráticos insuportáveis ${ }^{22}$.

Finalmente, uma precisão quanto ao uso do conceito de rede. A RNCCI integra diferentes instituiçóes, públicas e privadas, colocadas em diferentes níveis territoriais, relacionando-se entre si de uma forma hierarquizada e cooperando para produzir um resultado comum: os serviços de cuidados continuados. De fora ficam os doentes, os seus familiares e os cuidadores informais, que são concebidos como os destinatários ou beneficiários dos serviços produzidos pela Rede. Tomando como boa a distinção que Lemieux introduziu entre redes e aparelhos (Lemieux, 2000), segundo a qual os aparelhos são agrupamentos de agentes sociais organizados especificamente para fins de regulação externa dos públicos e assentando na distinção entre a organização que produz serviços e o público a quem a produção se destina, então estamos perante uma realidade que deve ser classificada como aparelho e não como rede. As redes não têm um público, apenas membros (sejam indivíduos, sejam instituições) e o seu modo de funcionamento é a auto-regulação (Godbout, 2004: 79). Esta precisão é útil para evitar os equívocos que a denominação rede pode suscitar: desde logo a ocultação de características típicas dos aparelhos burocráticos como a hierarquia e a autoridade, a rigidez e a universalidade.

\section{3. um sistema integrado de saúde e segurança social}

A originalidade deste programa relativamente aos anteriores consiste, como já foi referido, na multidimensionalidade dos cuidados prestados aos cidadãos dependentes, desde o apoio médico ao apoio social. Por isso, houve o cuidado de envolver os Ministérios da Saúde e do Trabalho e Solidariedade Social numa parceria que permita articular e coordenar as acçóes dos dois sectores.

Até hoje a coordenação dos apoios aos idosos, fora do quadro deste programa, tem sido difícil de estabelecer. Os serviços de cuidados ao domicílio assegurados por profissionais do Serviço Nacional de Saúde (SNS) cobrem as necessidades em matéria de tratamentos médicos e de cuidados de enfermagem enquanto que as necessidades de outra natureza, tais como a ajuda domiciliária de limpeza e manutenção e de refeiçóes ou a ajuda nas compras e no lazer são atribuiçóes da segurança social que opera principalmente através de instituiçôes de solidariedade social cuja presença ao nível local está muito desigualmente repartida. $\mathrm{O}$ que resulta mais flagrante nestes apoios é a falta de articulação entre eles e a duplicação de encargos que muitas vezes poderia ser evitada se houvesse uma programação concertada das ajudas entre os prestadores.

Dada esta experiência, a interacção e a cooperação de profissionais de distintas disciplinas e sectores foram reconhecidas expressamente como uma exigência pelo Programa RNCCI cuja intervenção de terreno opera através de equipas multidisciplinares e do trabalho interdisciplinar. Outrossim a delimitação clara das competências e a construção de

22 Refira-se, a propósito, que nos casos de permanência em unidades de internamento de média e de longa duração o internado tem de suportar um custo relativo aos cuidados de apoio social (o custo dos tratamentos de saúde será assegurado pelo SNS) de acordo com a sua capacidade económica ou da sua família. 
uma linguagem comum facilitadora da comunicação são consideradas indispensáveis neste quadro e, talvez por isso, a coordenação do Programa tem procurado definir a missão dos diferentes profissionais que intervêm nos cuidados cntinuados. Assim, relativamente aos assistentes sociais clarifica-se as distintas missóes a desempenhar pelos da saúde e pelos da segurança social. Enquanto a missão dos primeiros foi descrita como a de "enfatizar a relevância e a centralidade dos factores psicossociais, enquanto determinantes ou favorecedores do tratamento, da reabilitação, da readaptaçáo e da reintegração dos doentes/ dependentes nos ambientes sociais" mais adequados, a dos segundos é suposto centrar-se principalmente, nas questôes da "alocação de recursos requeridos para a efectivação dos cuidados em contexto não hospitalar, providenciando o acesso a prestaçóes sociais, a colocação em equipamentos sociais de apoio ou na disponibilização de serviços a doentes e famílias" (RNCCI, 2006).

Significativamente o documento que especifica estas distintas competências dos assistentes sociais foi elaborado pela Direcção-Geral da Saúde e reserva para os profissionais da saúde um conjunto alargado e exigente de atribuiçóes, nomeadamente no âmbito da dinamização e mobilização das comunidades locais ("O assistente social como capacitador de populaçóes e organizador de comunidades." ${ }^{23}$, que não valoriza a experiência e o conhecimentos próprios dos profissionais dos Centros Distritais de Segurança Social que trabalham nas comunidades. O mesmo se diga do não envolvimento das Redes Sociais concelhias ou, pelo menos, a náo consideração expressa dos documentos de diagnóstico e planeamento social por ela produzidos sobre os problemas sociais de cada concelho, incluindo os problemas de saúde.

\section{4. as famílias e a comunidade como elementos chave do sistema}

Nestas parcerias para a prestação de cuidados, os parceiros são organizações dominadas pelo seu corpo técnico ou representadas por um voluntariado solidário que não incorpora mecanismos de participação dos cidadãos, nomeadamente daqueles que a sua acção visa beneficiar.

E no entanto, tratando-se de uma intervenção que se propóe, em grande medida, substituir os cuidados informais de carácter familiar devia ser colocado um grande cuidado na participação das famílias dos utentes e das comunidades locais, pois são elas que constituem o contexto social de vida dos cidadãos utentes. Mesmo que os parceiros institucionais queiram assumir esse papel em nome destes cidadãos, é fácil de reconhecer que eles não têm legitimidade para representar os assistidos, designadamente nos momentos-chave do diagnóstico e planeamento da intervenção, porque não foram escolhidos por estes.

Na concepção do Programa de cuidados continuados, a família e a comunidade são vistos mais como um recurso do sistema do que como detentores de verdadeiros poderes de participação. Mais, espera-se delas que cooperem com o sistema com vista a aliviá-lo o mais possível do encargo de cuidar dos dependentes. Esta ideia transparecia claramente do

23 A organização comunitária é considerada nesse documento como uma dimensão nuclear do desempenho do assistente social da saúde e visa "a satisfação de necessidades dos cidadãos em prestação de cuidados ou serviços. Uso de metodologias de intervenção que visam o reforço ou o desenvolvimento do poder organizativo das populaçōes na satisfação das suas necessidades e prevêem a articulação e/ou cooperação entre recursos (públicos; privados lucrativos ou não lucrativos; formais ou informais), tendo em vista a prestação dos cuidados e dos serviços de proximidade necessários ao maior bem estar, autonomia e inserção social ou sócio-profissional dos doentes/dependentes" (RNCCI, 2006). 
preâmbulo do Decreto-Lei n. ${ }^{o}$ 281/2003, de 8 de Novembro. Depois de reconhecer que "na prestação de cuidados de saúde em geral a família e a comunidade social têm constituído (...) factores essenciais e indispensáveis no apoio aos seus concidadãos, nomeadamente aos mais frágeis e carenciados", afirma-se que "a sua iniciativa e acção são fundamentais, não apenas para evitar o prolongamento de estadas em regime de internamento por razóes alheias ao estado de saúde, como também para a reabilitação global e a independência funcional dos doentes, o apoio domiciliário e ocupacional de que necessitam e a reinserção social a que têm direito". Finalmente, na definição dos princípios a que o sistema deve obedecer, a família é reconhecida "como elemento determinante da relação humanizada, constituindo o suporte e lugar privilegiado para a pessoa carenciada" ( $\operatorname{art}^{\circ} 4^{\circ}, a l$. a). Ou seja, a família é vista sempre como um sujeito de responsabilidades sociais em vez de ser considerada na sua dimensão de co-actor público, sujeito activo de uma nova política de cuidados (Fontes e Martins, 2006: 37).

E, no entanto, faz todo o sentido integrar as famílias e as comunidades o mais possível neste processo de cuidados. É certo que em Portugal, não existe uma tradição de community care ou de saúde colectiva que desenvolva formas associativas de promoçáo de cuidados de saúde ou simples acçôes colectivas de defesa de interesses dos cidadãos e das famílias com problemas de saúde. Nem a saúde pública, nem a clínica geral/medicina familiar assumiram esse papel ou fomentaram a organização da comunidade em torno de objectivos de defesa e promoção da saúde: a saúde pública porque se tem confinado cada vez mais a uma intervenção do tipo sanitarista e a medicina familiar porque nunca soube passar do âmbito da família para o âmbito mais alargado da comunidade, ainda que tenha o grande mérito de ter compreendido a importância de reconhecer a interdependência existente entre os problemas de saúde individuais e o contexto familiar que os envolve.

Hoje conhece-se pouco das necessidades locais em saúde e, ainda menos, das preferências e expectativas da população. Contrariamente a outros domínios, como o das necessidades sociais básicas ${ }^{24}$ ou da educação, não existem na saúde programas de diagnóstico, planeamento ou coordenação da intervenção à escala local que permitam contrariar a orientação marcadamente individualista do nosso sistema de cuidados de saúde e assegurar aos cidadãos a oportunidade de exprimirem as suas preferências e as suas expectativas relativamente ao problema.

A participaçáo da comunidade a que nos referimos é muito mais do que a participação das famílias segundo as formas que foram previstas no Programa da RNCCI. Recorde-se que estas são chamadas a participar na elaboração dos "planos individuais de intervenção", ou seja, o conjunto dos objectivos a atingir com os cuidados continuados em cada caso face às necessidades identificadas; e ainda no encaminhamento dos doentes para as unidades e equipas da Rede ( $\operatorname{art}^{\circ} 6^{\circ}$, al.h). Num sentido mais positivo, mas de alguma forma não expresso na legislação, vai a preocupação, já assinalada anteriormente, de que os técnicos

${ }^{24}$ O Programa Rede Social, criado em 1997, instituiu um sistema permanente de recolha de informação social, de diagnóstico e planeamento da acção das instituiçóes locais e de coordenação da intervenção à escala dos concelhos e das freguesias. Também o Programa dos Territórios Educativos de Intervenção Prioritária (criado pelo Despacho n. ${ }^{\circ}$ 147-B/ME/96, de 8 de Julho de 1996) visa garantir as condiçôes para o sucesso educativo de todos os alunos de um determinado território, especialmente daqueles que se encontram em situaçóes de risco de exclusão social e escolar. As escolas integrantes de um território educativo elaboram projectos educativos, com a intervenção de vários parceiros, designadamente professores, alunos pessoal não docente, associaçốes de pais, autarquias locais, associaçóes culturais e associaçóes recreativas. 
sociais possam servir de agente animador, mobilizador e mesmo de provedor das comunidades a que as pessoas dependentes pertencem. Para que isso seja possível, muito terá de mudar nas práticas dos técnicos de saúde, na filosofia de intervenção dos serviços de saúde e na cultura profissional dos assistentes sociais.

\section{Conclusão}

$\mathrm{O}$ caso analisado ilustra eloquentemente as novas metodologias de intervenção que o Estado-Providência está a desenvolver nesta sua nova fase de evolução. De uma forma sintética, a nova geração de políticas sociais privilegia a actuação do Estado em parceria com organizaçóes da sociedade civil, a descentralização do desenho das medidas de política e a sua gestão partilhada pelas instituiçóes locais, a co-responsabilização do prestador e do beneficiário na aplicação das medidas, o efeito de proximidade em vez da solicitude distante, a flexibilidade das acçóes em vez da tipificação das valências. Pautando-se por princípios de eficácia e de cidadania, há que reconhecer que as políticas sociais são hoje mais exigentes na sua aplicação e também mais vulneráveis a distorçóes.

Dentre as metodologias usadas, a das redes institucionais tornou-se uma das mais correntes e de legitimidade mais amplamente reconhecida precisamente porque o parceiros da rede parecem partilhar do governo das políticas. E, contudo, a condição destas redes de parceiros não corresponde exactamente ao modelo das parcerias tradicionais da sociedade civil em que a adesão é negociada e produto de um cálculo estratégico por parte dos parceiros, em que os objectivos não estáo previamente fixados e em que não existem relaçóes burocráticas de autoridade e hierarquia entre os parceiros. No caso da RNCCI alguns parceiros (saúde e segurança social) estão vinculados ao mesmo programa de governo e relacionam-se entre si como agentes de um mesmo corpo, outros parceiros (órgãos da administração central e serviços desconcentrados) relacionam-se entre si de acordo com regras de hierarquia burocrática, outros ainda (serviços da segurança social e instituiçóes de solidariedade social) estão vinculados entre si por acordos de cooperação ou dispóem de um estatuto de utilidade pública atribuído pelo parceiro Estado). A atipicidade desta rede relativamente ao protótipo das redes sociais levaria a qualificá-la antes de aparelho burocrático (Lemieux) ou de partenariado (Rodrigues e Stoer, 1998).

Seja como for, o efeito simbólico que o uso da expressão rede confere ao próprio Programa obrigou-nos a questionar alguns aspectos que podem vir a tornar-se problemáticos no seu desenvolvimento. Primeiro, o de uma parceria que não resulta de um pacto antes funciona como um instrumento para agilizar a realização de objectivos pré-definidos. Segundo, o de uma implantação territorial de âmbito nacional que dá pouco espaço a fórmulas de auto-organização local e não inova suficientemente em relação ao sistema de administração centralizada tradicional no nosso país. A aparente descentralização das decisóes faz-se num quadro normativo bastante rígido, em termos de modalidades de intervenção, tipologia de utilizadores e regimes de financiamento. Terceiro, um sistema integrado de respostas que não leva tão longe quanto deveria a incorporação de competências e de experiências sectoriais distintas. A composição das equipas ainda é dominada pela perspectiva dos cuidados continuados como um problema fundamentalmente do âmbito da saúde, quando se sabe que, nas práticas de cuidados informais, as redes de parentesco, amizade e vizinhança ou seja, o capital social local, constituem a principal fonte de apoio e protecção. Finalmente, 
o papel deixado à família e à comunidade parece ser muito limitado e corresponder a uma ideia (tradicional) de que os grupos primários partilham a responsabilidade de cuidar dos seus dependentes e de que tudo o que se lhes exige é que colaborem com o Programa para este poder desempenhar a sua missão. É certo que alguns documentos que aprofundam o Programa defendem uma perspectiva mais avançada quanto à participação das famílias e de comunidade e à sua autonomia para propor e organizar respostas mais adequadas, mas a tradução disso na legislação é por enquanto nula. Resta saber como as coisas se vão passar no terreno...

\section{Referências bibliográficas}

CANOTILHO, José Joaquim Gomes; MOREIRA, Vital - Constituição da República Portuguesa. Anotada. Coimbra: Coimbra Editora, 2007.

EC - Modernising social protection for the development of high-quality, accessible and sustainable health care and long-term care: support for the national strategies using the "Open Method of Co-ordination", COM (2004) 304 final, 2004.

EC - Modernising social protection for the development of high-quality, accessible and sustainable health care and the long-term care: support for the national strategies using the "open method of coordination" Brussels, 20.4.2004 COM (2004) 304 final, 2004.

ESPING-ANDERSEN, Gosta - Three Worlds of Welfare Capitalism. Princeton: Princeton University Press, 1990.

EUROSTAT - Social Protection Expenditure and Receipts. Data 1995-2003. Luxembourg: Office for Official Publications of the European Communities, 2006.

EUROSTAT - At-risk-of-poverty rate after social transfers, by age group. 2007. (http://epp.eurostat.ec.europa.eu/ portal/page?_pageid=1996,39140985\&_dad=portal\&_schema=PORTAL\&screen=detailref\&language $=$ en $\&$ pr oduct=sdi_ps\&root=sdi_ps/sdi_ps/sdi_ps_mon/sdi_ps1112)

FERRERA, Maurizio - "The Southern Model of Welfare in Social Europe". Journal of European Social Policy. 6/1, 1996, pp. 17-37.

FONTES, Breno; MARTINS, Paulo - Redes, Práticas Associativas e Gestão Pública. Recife: UFPE, 2006.

GODBOUT, Jacques - "Digressão sobre as redes e os aparelhos". In Martins, Paulo Henrique, Fontes, Breno (orgs.) Redes Sociais e Saúde. Novas Possibilidades Teóricas. Recife: Editora Universitária UFPE, 2004.

HESPANHA, Pedro - "O lugar dos Actores Colectivos na Regulação Social: o caso das Instituiçóes Particulares de Solidariedade Social”. In SANTOS, Boaventura de Sousa et al., O Estado e Sociedade Civil: a criação de actores sociais num periodo de reconstituição do Estado. Relatório de Investigação. Coimbra: Centro de Estudos Sociais, 1998.

HESPANHA, Pedro et al. - Entre o Estado e o Mercado. As fragilidades das Instituiçôes de Protecção Social em Portugal. Coimbra: Quarteto, 2000.

HESPANHA, Pedro; PORTUGAL, Sílvia - A Transformação da Família e a Regressão da Sociedade-Providência. Porto: Comissão de Coordenação da Regiâo Norte, 2002.

LEIBFrIED, S; PIERSON, P. - "Prospects for a Social Europe". Politics and Society. 20(3), 1992, pp. 367-375.

LEMIEUX, Vincent - À Quoi Servent les Réseaux Sociaux? Sainte-Foy: IQRC, 2000.

OECD - Long Term Care for Older People. Paris: OECD, 2005.

PNAI - Plano Nacional de Acção Para Inclusão. Portugal 2006-2008. Lisboa: Ministério do Trabalho e da Solidariedade Social, 2006.

RHODES, Martin - "Southern European Welfare States: Identity, Problems and Prospects for Reform". South European Society and Politics - Special Issue on Southern European Welfare States. vol.1, no 3, 1996, pp. 1-22.

RNCCI - Manual de Boas Práticas para os Assistentes Sociais da Saúde na Rede Nacional de Cuidados Continuados Integrados. RNCCI, 2006. (http://www.rncci.min-saude.pt/NR/rdonlyres/DE3DCDED-B8C2-4E56-86B966761CCF3B73/7177/ManualBoasPraticasASSRNCCI.pdf)

RNCCI - Relatório de Monitorização da Implementação das Experiências Piloto da Rede Nacional de Cuidados Continuados Integrados. Lisboa: Cuidados Integrados, 2007.

RODRIGUES, Fernanda; STOER, Stephen - Entre Parceria e Partenariado. Oeiras, Celta, 1998.

RODRIGUES, Fernanda - Assistência Social e Politicas Sociais em Portugal. Lisboa: Ediçôes ISSS, 1999. 
SOUSA, Liliana; HESPANHA, Pedro; RODRIGUES, Sofia; GRILO, Patrícia - Famílias Pobres: Desafios à Intervenção Social. Lisboa: Climepsi Editores, 2007.

UEMO (www.uemo.org/history/a_challange_for_uemo_2002_htm)

Van PARIJS, Philippe - "Rendimento Básico: Rendimento Mínimo Garantido para o Século XXI?". In IDS, Actas do Seminário Políticas e Instrumentos de Combate à Pobreza na Uniāo Europeia. Almancil, 2000. tionand comparison of integrated care in six EU countries. Maarsen: Elsevier Gezondheidszorg, 2003. 
Breno Augusto Souto Maior Fontes

\section{Redes Sociais e Saúde Mental}

\section{Introduçáo}

A agenda das reformas do sistema de saúde conta com um capítulo importante, o da reforma do sistema de saúde mental. Desde a década de 60 diversos países do mundo inteiro empreendem tentativas de introduzir novas práticas no tratamento dos portadores de transtorno mental. As denúncias de Goffman e Foucault, deslocando o foco do discurso psiquiátrico e sua prática terapêutica, para uma abordagem humanística, integradora e, conseguentemente, que tivesse a preocupação com o indivíduo em sua totalidade - não aquele classificado, medicalizado e naturalmente circunscrito aos diversos campos da área médica são o estopim do processo.

Com as reformas no sistema de atenção aos portadores de transtorno mental, reintroduz-se o indivíduo na sociedade, convidando outros atores para a participação no processo de seu tratamento. Reconhece-se a importância das redes sociais, dos apoios sociais consequentes desta inserçâo em campos de sociabilidade mais amplos, tanto do ponto de vista da reconstrução de um cotidiano, muitas vezes perdido pelo sofrimento psíquico, e também como importante auxiliar no tratamento, a partir dos diversos dispositivos de apoio e de solidariedade oferecidos por atores não inscritos no campo médico.

Há um elemento a considerar, o da construção social do doente mental. É sabido que os "loucos" no passado eram simplesmente isolados do convívio social, seja pela pura e simples expulsão da comunidade ${ }^{1}$, passando pelas casas de internamento e até pela terapêutica moderna, inaugurada por Pinel, onde o asilo, local de tratamento era também local de confinamento e de exclusão. O sentido do internamento, embora as instituiçóes se tenham mantido relativamente inalteradas, começa a mudar. A loucura é agora compartimentalizada em campos discursivos próprios, é instrumentalizada por técnicas terapêuticas. Mas o doente mental ainda é objeto de exclusão, isolamento e até condenação moral. O doente mental, isolado em um manicômio, lentamente é acometido do que Goffman chama de "morte social": desestruturação completa de seus laços de sociabilidade, interiorização dos padrôes institucionalizados da rotina hospitalar, a ponto de louco e hospital se confundirem.

\footnotetext{
1 "Os loucos tinham entâo uma existência facilmente errante. As cidades escorraçavam-nos de seus muros; deixava-se que corressem pelos campos distantes, quando náo eram confiados a grupos de mercadores e peregrinos" (Foucault, 2005: 9).
} 
Analisar redes sociais de portadores de transtorno mental significa levar em consideração a particularidade do estigma da doença mental e o processo de (des)estruturação social resultante da trajetória do doente mental. Significa incorporar o campo institucional (os profissionais de saúde e suas instituiçôes: os hospitais, os manicômios, os centros de atendimento) porque nestes espaços passam a acontecer parte significativa do cotidiano dessas pessoas, o campo das sociabilidades secundárias destas pessoas e de seus cuidadores²: associaçóes de moradores, ONGs, Igrejas; os campos de sociabilidade primária dos doentes mentais: amigos, parentes, colegas de trabalho, vizinhos. Pessoas com quem se relacionam e de onde retiram apoio para o enfrentamento de seu sofrimento psíquico.

\section{Apoio social ou como as pessoas constroem solidariedade}

As redes de apoio dos portadores de transtorno mental estão bastante ancoradas na sociedade civil (associaçóes, ONGs,) e na esfera privada (famílias, amigos, redes primárias de forma geral), que inclui, deste modo, além dos profissionais do campo médico, familiares, amigos, associaçóes e grupos de apoio.

$\mathrm{Na}$ literatura consultada, encontramos uma rica discussão sobre o fenômeno da "solidariedade": sobre como se manifesta este fenômeno, como em diversas civilizaçóes acontece esta prática ${ }^{3}$. Em literatura mais específica sobre cuidados com portadores de transtorno mental, encontramos um debate sobre apoio social, refletindo sobre como o fenômeno da solidariedade se manifesta neste campo de sociabilidade particular. Apresentamos, aqui, de forma sumária, um breve relato deste debate ${ }^{4}$.

Contemporaneamente, as ações estruturadoras da solidariedade se localizam principalmente no mercado e no estado, definindo as açóes sociais dominantes, calcadas na racionalidade instrumental: o dinheiro e o poder (Habermas, 1978). Os intercâmbios estabelecidos entre os atores não se dão de forma pontual e localizada, como é o caso das situaçóes de troca de mercado entre consumidores, ou nas relaçóes do Estado na provisão de serviços públicos, caracterizando também uma relação localizada entre o produtor de bens e o detentor de direitos (o cidadão). As açóes não estabelecidas pela racionalidade instrumental, entretanto, sempre estiveram presentes e se constituem em instrumento indispensável à manutenção do tecido social. Localizando-se na esfera do mundo da vida (e definidas operacionalmente pela racionalidade substantiva), estas açôes produzem solidariedade de outro nível. A solidariedade produzida na esfera do mundo da vida se dá a partir de trocas não circunscritas em um espaço de tempo, traduzindo-se antes de tudo pela reafirmação de laços sociais que se prolongam por uma trajetória de sociabilidade não necessariamente inscrita na contabilidade da equivalência de objetos que se intercambiam. A troca se dá a partir do dom.

\footnotetext{
2 Os cuidadores, quando existem, são membros da família, com forte presença feminina (mães, esposas e filhas).

${ }^{3}$ Neste caso, a importante discussão de Mauss, com o seu ensaio sobre a dádiva, que ainda hoje inspira muitos acadêmicos.

${ }^{4}$ Já apresentamos, em outro local (Fontes: 1999) uma revisão da literatura sobre redes sociais e solidariedade. Introduziremos aqui algum comentário sobre este assunto, ligando-o à literatura sobre apoio social (social support), de origem predominantemente norte-americana, que procura explicar a importância dos vínculos sociais para a saúde das pessoas, e também para o enfrentamento das adversidades.
} 
Os processos de solidariedade originários a partir do fenômeno do dom e ancorados no cotidiano se constituem em elemento fundamental na estruturação do vínculo social. Primeiro, como nos mostra Godbout, a partir da transformação do indivíduo em pessoa, "sujeito que se posiciona em uma série de atos de direitos e obrigaçôes, de dívidas e créditos, que desenham sua existência concreta, que estabelece o lugar real, simbólico ou imaginário, onde as pessoas entram em interação... lugar de interconhecimento direto e concreto seja efetivas - relaçóes face a face ou simplesmente virtuais" (Godbout, 1992: 197). Depois, o estabelecimento da reciprocidade e da interdependência mútua que caracteriza a estruturação da sociedade, como nos mostra Gouldner (1960). Este processo de certa forma complementa as atividades inscritas na esfera econômica, onde o padrão de troca, levado a cabo a partir da divisão do trabalho, é realizado, resultando na interdependência entre as pessoas.

Como funcionam estes mecanismos de solidariedade? Desde Durkheim, em seu clássico "da divisão do trabalho social", os processos geradores de solidariedade, fundamentais para a manutenção do laço social, estão associados à interdependência entre os indivíduos em suas atividades cotidianas. Deste modo, as instituiçóes sociais, locais de desempenho dos papéis sociais, seriam o lócus das práticas de solidariedade. Das práticas de solidariedade, identificadas por Mauss (2003) enquanto produtoras de "dádiva", ou aquelas encontradas no mercado, não haveria diferenças significativas no que diz respeito às suas características básicas (geradoras de interdependência, estabelecedoras de vínculo social, etc.). A localização destes processos de sociabilidade, entretanto, se daria de maneira diferente.

Nas sociedades modernas, aparentemente, haveria uma predominância das práticas sociais orientadas pelo dinheiro ou pelo poder, segundo a tese de Habermas 5 . As outras práticas (estruturadas no mundo da vida), entretanto, não desaparecem; inclusive, são de vital importância para o funcionamento destas sociedades (é a tese de Godbout). Estas práticas se estruturam a partir da construção de redes sociais centradas nos processos de sociabilidade vivenciados pelos indivíduos em seu cotidiano.

No campo dos cuidados de saúde, estes não se restringem aos profissionais da área médica. Como vimos, parte importante dos atores está localizada em campos de sociabilidade da sociedade civil (associaçôes voluntárias, ONGs) e na esfera privada (as redes de sociabilidade primária - família, vizinhos, amigos). Existe uma intensa literatura que trata do assunto, descrevendo este fenômeno pelo nome de "Apoio Social", que pode ser definido como "o conjunto de provisóes instrumentais ou expressivas, reais ou percebidas, levado pela comunidade, redes sociais e amigos íntimos” (Peña, 2003). Segundo Peña, devem ser considerados três níveis de análise dos mecanismos que ativam o Apoio social: (a) a comunidade; (b) as redes sociais; (c) as ligaçóes mais íntimas, que proporcionam um vínculo mais estreito (Реña, 2003).

O apoio social está ligado ao fenômeno do dom, de manifestação mais larga que cuidados a pessoas. É uma forma de circulação de recursos aportada por práticas de sociabilidade fora do mercado e do Estado. Em uma manifestação mais particular, a de cuidados a doentes ou pessoas com necessidades, ou a atenção e conforto psicológico resultantes desta relação, o apoio social tem efeitos muitos conhecidos na saúde das pessoas e, indiscutivelmente, não pode ser substituído pela atenção proporcionada pelo Estado. ${ }^{6}$

${ }^{5}$ Esta progressiva interdependência entre os indivíduos, ao lado de uma individualização crescente, provocada pela economia monetária, é exemplarmente analisada em Simmel (1983).

6 Consultar a respeito Badura (1986). 
O apoio social mobiliza recursos na forma de apoio emocional ou de cuidados para o tratamento e acompanhamento da doença que podem ser alocados na esfera privada, a partir das redes primárias de sociabilidade (amizade, família, vizinhos) ou no campo da sociedade civil, a partir das redes secundárias (ONGs, associaçóes de apoio, etc.). Os vínculos sociais estabelecidos entre as pessoas, resultam em uma prática que não se ancora em uma racionalidade típica do mercado ou do Estado, a instrumental. Trata-se de um campo específico, que denominamos de redes sócio-humanas, que fazem parte do complexo sistema que estrutura o cuidado e atenção à saúde (ao lado das redes sócio-técnicas e sócio-institucionais), mas com uma lógica própria.

Insisto no fato de que estas sociabilidades se desenvolvem com uma lógica própria, não sendo, portanto, passível serem substituídas por outras lógicas, e que a sua existência é indispensável a uma prática adequada de cuidados a pessoas que mereçam atenção especial (doentes e idosos, por exemplo). A literatura sobre portadores de transtorno mental é bastante clara a este respeito: os benefícios do apoio social sobre a saúde física e mental das pessoas não são aportados de outra forma a náo ser a partir da complexa relação estabelecida a partir do vínculo ancorado no dom.

Sobre os cuidados com os portadores de transtorno mental: a reforma psiquiátrica e o desasilamento

Na década de 60, na Europa, inicia-se um movimento que pôe em questão a até então dominante prática de tratamento dos doentes mentais, o asilamento, o isolamento em manicômios. Beneficiadas de certa forma pela revolução do tratamento provocada pela descoberta e aperfeiçoamento de uma série de medicamentos, estas pessoas podiam mais facilmente controlar suas crises e, portanto, ter a oportunidade de uma assistência domiciliar. Abre-se a possibilidade de questionar o modelo terapêutico dominante, fortemente autoritário: pessoas isoladas do convívio social, estigmatizadas e, segundo os críticos mais mordazes, cada vez mais assujeitadas à cultura manicominial.

As causas da doença mental são agora também atribuídas, ao lado dos processos de natureza biológicas, a processos sociais. O internamento em manicômios, desconsiderando esta questáo, poderia exercer efeitos contrários ao esperado, o de controle e cura da doença. Defende-se agora o tratamento domiciliar, a reconstruçáo das redes sociais e o empoderamento do doente mental. Este processa-se a partir do momento em que o indivíduo se póe em contato mais intenso com a família, com os amigos, enfim, quando cada vez mais se aproxima de uma rotina de sociabilidade "normal"7.

No Brasil, a reforma psiquiátrica é resultado de um longo processo onde não somente os aspectos mais específicos da organização dos serviços de saúde mental são considerados, mas o sistema de saúde como um todo. Podemos afirmar que o movimento pela reforma psiquiátrica no Brasil faz parte do movimento pela reforma sanitária, que culminou na implantação do SUS (Sistema Único de Saúde) no início da década de 90.

A reforma sanitária faz parte de um grande processo descentralizador, com origens na Europa na década de 1970, chegando à América Latina na década seguinte, com a crise de legitimação dos regimes militares. Inaugura-se no continente uma vaga descentralizadora, e o poder local se converte em um denominador comum: é a principal bandeira de luta dos

${ }^{7}$ Consultar a respeito Legewie e Wiedermann (1986). 
movimentos populares, de todos os partidos de esquerda, assim como dos projetos políticos conservadores e também apoiado por agências internacionais de desenvolvimento.

Participação popular e descentralização são os ingredientes de uma fórmula mágica, espécie de panacéia para as frequentes crises de legitimação experimentadas pelas democracias ocidentais, com a consequente deslegitimação de seus instrumentos de organização política mais importantes, os partidos e os sindicatos. Os novos atores sociais passam a ser os principais agentes desta nova ordem política, instituída enquanto projeto restaurador dos ideários da democracia. Trata-se, na verdade, de um projeto que pretende encontrar uma fórmula que, de certo modo, corrija os vícios da democracia representativa (sem descartá-la), resgatando o princípio da universalidade, da possibilidade de existência de um foro para todos os segmentos da sociedade civil.

A ação descentralizadora, vista como um processo administrativo cujo objetivo é o aumento da eficiência com o aproveitamento racional dos recursos públicos disponíveis deve considerar a esfera pública (lugar por excelência para a decisão sobre a produção de bens públicos) como um instrumento potencialmente poderoso para lograr a justiça social. Neste sentido, o processo descentralizador surge indissoluvelmente ligado ao componente participativo, ferramenta de ampliaçáo do acesso da sociedade civil à tomada de decisôes.

A gestão participativa tem o conteúdo particularmente ancorado no local. Argumenta-se que as questóes locais afetam mais diretamente o cotidiano das pessoas e que, portanto, devem ser resolvidas localmente. A esfera político-administrativa local, o município, deve organizar padróes de gestáo onde o componente participativo seja o principal instrumento. A transferência, pois, de competência decisória a comunidades locais é o ingrediente fundamental do processo descentralizador, significando distribuição de poderes.

No Brasil, as experiências das décadas de 70 e 80 mostram que, muito além de meras declarações de princípios, as práticas de participação popular na gestão urbana se propagaram de forma impressionante por todas as partes. Entretanto, mesmo conduzidas por atores sinceramente empenhados em fazer valer os princípios de uma prática verdadeiramente democrática, estas experiências geraram também novos problemas. Examinando a literatura destas décadas, e comparando com escritos mais recentes, verificamos uma significativa contradição: de um lado, o otimismo, apoio e entusiasmo em relação à funcionalidade destes novos sistemas de gestão; por outro, certo descontentamento ao constatar que as coisas não funcionam tão bem como se previa.

A reforma Sanitária e a consequente descentralização do Sistema de Saúde talvez seja uma das mais bem sucedidas experiências de descentralização. Com amplitude nacional, e fortemente regulamentada - garantindo desta forma recursos, base institucional para execução e consequente diminuição do risco de descontinuidade das políticas - esta reforma é o resultado de um intricado jogo político, com atores se enfrentando na regulaçáo de um sistema complexo - o da gestão de políticas de saúde - envolvendo interesses frequentemente em conflito. É o resultado da mobilização dos militantes da saúde pública, inconformados com uma prática médica dominante ancorada na especialização, fortemente orientada para açôes curativas e com cada vez mais presença de interesses privados. A luta pela reforma sanitária traz como principal tópico da agenda o da universalização do acesso, de um lado, e uma ênfase em práticas de promoçáo de saúde, de outro.

O desenho do modelo é bastante complexo: desde a base (os municípios) até ao topo da hierarquia administrativa brasileira (a Federação) são introduzidos mecanismos de partici- 
pação popular, com os Conselhos de Saúde, formados por representantes da sociedade civil. Estes Conselhos e as Conferências de Saúde, definem a agenda da saúde pública do país.

O conteúdo pleno desta prática de cuidados de saúde envolve, consequentemente, não somente um modelo de gestáo descentralizada e participativa - que no sistema de saúde se estrutura para a definição das agendas a partir dos Conselhos e das Conferências - mas também uma intensa relação entre a equipe de saúde da municipalidade e a população, a partir das redes das comunidades onde habitam, vivem e constroem seus cotidianos. A saúde náo é mais objeto de atenção do indivíduo e seu corpo com o cuidador: é o cuidado do corpo, do estado de sanidade, incorporado à promoção da saúde, à participação da comunidade e suas associaçóes e também ao envolvimento das famílias, dos vizinhos. Trata-se, portanto, de uma concepçáo onde a construção e o resgate destas redes comunitárias e primárias são o conteúdo principal.

Em 6 de Abril de 2001 é promulgada a Lei n. 10.216, que dispóe "sobre a proteção e os direitos das pessoas portadoras de transtornos mentais e redireciona o modelo assistencial em saúde mental". Esta lei se baseia em um projeto do Deputado Paulo Delgado, que tramitou no Congresso Nacional por mais de uma década. A sua versão final foi apresentada a partir de um substitutivo do Senador Sebastião Rocha. Esta Lei formaliza uma prática que há algum tempo tem sido adotada em algumas cidades brasileiras ${ }^{8}$, a de oferecer um modelo de assistência diverso do até entáo existente, o do internamento hospitalar, e a de estimular o apoio da comunidade e dos laços primários do assistido enquanto instrumento central do tratamento. Com efeito, o artigo 2, Parágrafo Único, IX afirma ser direito fundamental da pessoa portadora de transtorno mental "ser tratada, preferencialmente, em servicos comunitários de saúde mental; o artigo 4., $\$ 3$ veda a internação de pacientes portadores de transtorno mental em instituiçôes com características asilares".

O modelo de assistência e de tratamento segue o mesmo padrão ditado pelas diretrizes da reforma sanitária: territorialização, participação comunitária e ambiente multidisciplinar. Para o caso dos portadores de transtorno mental, instituem-se os CAPs (Centros de Atenção Psicossocial), com as seguintes características:

“... devem oferecer condiçôes que inexistem nos ambulatórios, no sentido de uma atenção diária e integral; devem ser regionalizados e oferecer um tratamento dito comunitário ou territorializado; isto é, que não retire o paciente de seus vínculos sociais e baseie-se não apenas nos recursos da instituição mas nos recursos comunitários; devem oferecer possibilidades expressivas, relacionais, de atividades e de convivência diversificadas e devem incorporar à acáo terapêutica iniciativas de ajuda concreta à existência global do paciente antes tidas como extraclínicas"(Tenório, 2002: 50).

Como consequência principal, o declínio do número de leitos em hospitais psiquiátricos, que passa de 72.514 em 1996 para 53.180 em 2003, um decréscimo de 26,6\%, com a progressiva instalação dos CAPs e a inauguração de uma nova prática terapêutica. Como consequências secundárias, os autores têm apresentado alguns efeitos às vezes inesperados ou não desejados, seja pelo não cumprimento integral do modelo, seja por inadequaçóes da nova proposta de intervenção aos ditames da resistência cultural ou mesmo dos profissionais de saúde mental. Alguns pontos merecem ser considerados:

(a) a descentralizacão e as interfaces entre os diversos niveis politico-administrativos. Silva (2003) afirma que "a implementação dos princípios do SUS - como a descentralização da

\footnotetext{
${ }^{8}$ Por exemplo, a experiência de Santos, do NAPS (Núcleo de Assistência Psicossocial), tem início na década de 90.
} 
gestão, a atençáo integral e a participação da comunidade - desencadeia tantos processos político-administrativos, gerando conflitos entre recursos e responsabilidades. Esse processo de descentralização acaba encarregando mais do que empoderando municípios, serviços e profissionais".

(b) O desengajamento do Estado - já há algum tempo os especialistas alertam que os processos descentralizadores podem resultar em transferência de responsabilidades desacompanhadas de recursos adequados e que este fato implica concretamente em uma oferta dos serviços reduzida. A mesma questão tem sido apontada por especialistas da reforma psiquiátrica: "deve-se ter o cuidado para que o Estado não se exima por completo de sua responsabilidade, ao transferir o atendimento a pacientes psiquiátricos para unidades fora de sua rede. A transferência do cuidado dos usuários de saúde mental para CAPs municipais e até para aqueles administrados por organizaçôes da sociedade civil não pode significar a desresponsabilizacáo do Estado. Para o Ministério da Saúde é cômodo e econômico tirar dos hospitais os pacientes internados, como acontece com os beneficiados pelo Programa de Volta para Casa9 . Neste caso, o usuário dos serviços de saúde mental recebe um benefício de um salário mínimo. Caso continuassem os internamentos, o MS gastaria cerca de 3,5 vezes mais por cada paciente (Mattar, 2004). Também deve ser considerado o fato de que em países de baixo ou médio desenvolvimento, o Estado do Bem Estar Social não se desenvolve de forma satisfatória, o que faz com que as famílias ou grupos da sociedade civil sejam os provedores principais dos cuidados. Há um risco bastante alto que com a reforma, a desinstalação dos manicômios não seja acompanhada pela substituição dos serviços antes ofertados por outros, o que resulta na maior presença do que Alves (1998) denomina Sociedade-Providência:

"A Política de Saúde Mental em Portugal é analisada a partir do conhecimento dos modos de produção de respostas na saúde mental. ... Portugal é uma sociedade semi-periférica, e a sociedade providência [é constituída de modo particular] em que as redes de solidariedade que se processam na base de laços de parentesco (a família) aparecem como forma de resposta social aos problemas que a doença mental coloca.

A nossa hipótese anuncia a contradição encontrada a nível das Políticas de Saúde Mental entre o definido legalmente (Psiquiatria Comunitária de Inserção social) e a realidade prática (exclusão social) e introduz as famílias e portanto a sociedade-providência como fundamental nesta análise" (Alves, 1998, pp. 6-7).

(c) Finalmente, deve-se considerar se efetivamente há um ambiente sócio-cultural ao estabelecimento de práticas previstas na reforma psiquiátrica. De um lado, se há efetiva densidade associativa, consequentemente, se as condiçôes de participação são preenchidas; se as comunidades dispóem de densidade adequada de capital social, permitindo, desta forma uma efetiva participação. Por outro, se os diversos atores envolvidos diretamente nos cuidados (profissionais de saúde em geral, membros das redes primárias dos pacientes envolvidos diretamente na sua assistência) assimilam o conteúdo ou a filosofia desta nova prática, incorporando-a sem resistências, ou se, diante de um quatro institucional novo, velhas mentalidades ainda persistem. Se, por exemplo, as famílias - por conta da difícil tarefa de lidar com o preconceito, o estigma e a exclusão - julguem mais adequada a prática tradicional do asilamento e que, na impossibilidade prática de internar o portador de

9 Programa que dispóe sobre auxílio monetário aos portadores de transtorno mental, ou seu representante legal instalado a partir da Lei n. 10708 de 31 de julho de 2003. 
transtorno mental, o isole em sua residência e o exclua do convívio social; ou se a equipe de saúde ainda considere mais eficaz o tratamento medicamentoso, utilizando-o preferencialmente a outro que se apresente como alternativo.

\section{Referências Bibliográficas}

ALVES, Maria de Fátima Pereira - A família como suporte da política de saúde mental em Portugal. Porto: Instituto Superior de Serviço Social do Porto, 1998 (Dissertação de Mestrado).

BADURA, Bernhard - "Social networks and the quality of life". In: FRICK, Dieter (Ed.) The quality of urban life. Social, psychological and physical conditions. Berlin: Walter de Gruyter, 1986, pp. 55-61.

FONTES, Breno Augusto Souto Maior - "Capital Social e Terceiro Setor: Sobre a estruturação das redes sociais em associaçôes voluntárias”. Cadernos do CRH, 30/31, 1999, pp. 239-264.

FOUCAULT, Michel - História da Loucura. São Paulo: Ed. Perspectiva, 2005.

GODBOUT, Jacques - L'esprit du don. Paris: Edition la Découverte, 1992.

GOULDNER, Alvin - "The norm of reciprocity: a preliminary statement". American Sociological Review, no 25, 1960, pp. $161-178$

HABERMAS, Jürgen - Raison et légitimité. Problèmes de legitimation dans le capitalisme avancé. Paris: Payot, 1978.

LEGEWIE, Heiner; WIEDERMANN, Peter M. - "Part E: Mental Health - Introduction”. In FRICK, Dieter (Ed.) The quality of urban life. Social, psychological and physical conditions. Berlin: Walter de Gruyter, 1986, pp. 219-227.

MATTAR, Maria Eduarda - "Mais reforma em mente". La insignia. 10 de outubro de 2004.

MAUSS, Marcel - Sociologia e Antropologia. São Paulo: Cosac \& Naïf, 2003.

PENAA, Roser Fernandes - "Redes Sociales, apoyo social y salude". Periferia. no 3, 2003. (disponível no site www. periferia.name )

SILVA, Pedro Luiz Barros - "Serviços de Saúde: o dilema do SUS na nova década”. São Paulo em Perspectiva, 17(1), 2003, pp. 69-85.

SIMMEL, Georg - "Sociabilidade - um exemplo da sociologia pura ou formal". In FILHO, Evaristo Morais (organizador da coletânea). Sociologia. São Paulo: Ática, 1983, pp.165-181.

TENÓRIO, Fernando - "A reforma psiquiátrica brasileira na década de 80 aos dias atuais". História, Ciências, Saúde. Vol. 9(1), 2002, pp. 25-59. 
Eliane Maria Monteiro da Fonte

\section{Desafios na Avaliação dos Serviços de Saúde Mental NO CONTEXTO DA DESINSTITUCIONALIZAÇÃo}

\section{Introdução}

Os cuidados psiquiátricos no Brasil consistiam basicamente em hospitalização até os anos 1980, quando mudanças nas políticas de saúde mental propuseram a sua transferência para serviços de base comunitária. A reforma psiquiátrica consistiu na tentativa de dar ao problema da loucura uma outra resposta social, não asilar; evitar a internação como destino e reduzi-la a um recurso eventualmente necessário, permitindo aos portadores de transtorno mental ${ }^{1}$ manter-se na sociedade. Mudar o tratamento dado ao doente mental consiste em duas grandes açóes: oferecer uma rede de cuidados que ajude o paciente a viver na comunidade e construir uma atitude nova da sociedade em relaçáo ao doente mental. Os processos de reforma psiquiátrica em curso no Brasil apontam hoje para a necessidade de se avaliar seus resultados. A falta de informaçóes consistentes sobre os pacientes que estão sendo afetados por estas mudanças, torna difícil se avaliar o impacto dos novos serviços de base comunitária, o tratamento efetivo e suporte dado aos seus usuários e suas famílias.

Este artigo tem como objetivo contribuir para a discussão de parâmetros, critérios e indicadores a serem utilizados na avaliação das políticas de saúde mental no Brasil, ou mais especificamente, no que se refere à atenção psicossocial provida pelos serviços saúde mental de base comunitária. A avaliação no campo da atençáo psicossocial tem certas especificidades que os indicadores tradicionalmente utilizados pela clínica, tais como número de consultas, internaçóes, remissão de sintomas, diagnóstico, número de altas, entre outros, são incapazes de captar. Considerando-se o modelo de cuidado psiquiátrico adotado, ganha destaque a necessidade do desenvolvimento de metodologias capazes de captar o processo de desinstitucionalização em curso e de se estabelecer relações entre aquilo que efetivamente é realizado e o que se espera que os serviços substitutivos ofereçam e o que está definido como esperado como resultado desta intervenção.

O presente artigo está estruturado da seguinte forma: a primeira seção caracteriza os avanços da reforma psiquiátrica brasileira; a segunda seção apresenta o modelo substitutivo

1 Paciente psiquiátrico, usuário de serviço de saúde mental, portador de transtorno mental, doente mental, louco, psicótico e portador de sofrimento psíquico intenso, são algumas das terminologias utilizadas para designar aquelas pessoas em tratamento psiquiátrico na rede pública. Embora cada uma delas reflita uma determinada concepção teórica do fenômeno da loucura e política da assistência pública em saúde, utilizaremos de forma alternativa os diversos termos. 
ao centrado na internação hospitalar adotado no Brasil, que prioriza a atendimento comunitário e preza pela manutenção do paciente psiquiátrico em seu meio familiar e comunitário. A título de conclusão, a última seção discute a questão da avaliação dos serviços de saúde mental no Brasil, ressaltando-se a necessidade de se desenvolver processos avaliativos capazes de superar os tradicionalmente utilizados pela clínica psiquiátrica, considerados insuficientes para avaliar os serviços criados a partir da reforma psiquiátrica.

\section{A Reforma Psiquiátrica e o processo de desinstitucionalização no Brasil}

O tratamento asilar de loucos foi sendo modificado, questionado e mesmo substituído desde o pós-guerra em vários países. Apesar disso, observa-se uma grande expansão da rede de hospitais psiquiátricos no Brasil a partir da década de 1960. Foram os governos militares que consolidaram a articulação entre internação asilar e privatização da assistência, com a crescente contratação de leitos nas clínicas e hospitais psiquiátricos conveniados. As internaçôes passaram a ser feitas, não apenas em hospitais públicos, mas em instituiçóes privadas, que eram remuneradas pelo setor público para isso. ${ }^{2} \mathrm{Na}$ maioria das vezes, as clínicas contratadas funcionavam totalmente as expensas do Sistema Único de Saúde (SUS) antes via INPS (Instituto Nacional de Previdência Social). Sua única fonte de receita era a internação psiquiátrica, remunerada na forma de diária paga para cada dia de internação de cada paciente.

Como na psiquiatria, ao contrário de outras especialidades da medicina, a indicação de internação nem sempre é clara ou indiscutível, a decisão, com grande margem de escolha, fica a critério do médico ou da família do paciente. Como o pressuposto disseminado no meio especializado e na sociedade era de que lugar de louco é no hospício, e diante da inexistência de dispositivos de assistência intensiva alternativos ao modelo asilar, o sistema impulsionava a internação, mesmo onde havia boa fé (Tenório, 2002: 34). O sistema e a mentalidade vigentes estavam organizados em torno da internação (e da internação prolongada), as empresas hospitalares auferiam benefícios significativos com as internaçôes (sua única fonte de lucro), com total falta de controle pelo estado, observando-se um verdadeiro empuxo a internação, razão pela qual este sistema veio a ser chamado de "indústria da loucura".

A discussão acerca da necessidade de humanização do tratamento do doente mental teve início na década de 1970, momento em que diversos setores da sociedade brasileira se mobilizaram em torno da redemocratização do país. A Associação Brasileira de Psiquiatria/ABP, em açóes políticas para defender médicos que haviam sido presos e torturados, revitalizou, no cotidiano profissional, discussóes éticas acerca dos direitos humanos e da necessidade de ampliação dos direitos individuais no país (Firmino, 1982: 35). Apelos para que "ninguém fosse submetido à tortura, a tratamento ou castigo cruel, desumano e degradante" e nem "arbitrariamente preso, detido ou exilado" foram estendidos para a

2 O direcionamento do financiamento público para a esfera privada durante o regime militar pode ser percebida no fato de que entre 1965 e 1970 a população internada em hospitais públicos permaneceu inalterada, enquanto a clientela das instituiçóes privadas remuneradas pelo setor público saltou de 14 mil para 30 mil, chegando a uma proporção de $80 \%$ de leitos contratados junto ao setor privado e $20 \%$ diretamente públicos (Tenório, 2002: 34). 
condição de opressão do doente mental nos manicômios e sua humilhação moral na sociedade em geral. Os hospitais psiquiátricos, centralizando a assistência e sendo praticamente únicos na oferta de serviços psiquiátricos no contexto nacional, tiveram as condições internas de maus-tratos aos internados desnudadas e denunciadas no processo social brasileiro de "abertura democrática". A discussão acerca da violência, dos maus tratos e da tortura praticada nos asilos brasileiros produziu, em grande parte, a insatisfaçáo que alimentou o Movimento Antimanicomial. Entretanto, ainda não havia muito claro qual deveria ser o modelo de cuidado e nem uma proposta estruturada da intervenção clínica.

Neste período vários movimentos de contestação ao saber e prática psiquiátrica instituídos se fizeram notar no cenário mundial, dos quais se destacam os movimentos denominados Psiquiatria de Setor, na França; as Comunidades Terapêuticas, na Inglaterra; e a Psiquiatria Preventiva, nos EUA. ${ }^{3}$ Esses movimentos se caracterizaram por visar uma reforma do modelo de atenção psiquiátrica, propondo rearranjos técnico-científicos e administrativos da psiquiatria. Neste processo cabe mencionar a importância significativa do conceito de reforma da "psiquiatria democrática" italiana, concebido por Franco Basaglia (1981) que, na década de 1960, foi um dos primeiros a estabelecer tratamento psiquiátrico sem o uso da instituição asilar, apontando para o fim dos manicômios, começando a se articular o paradigma da desinstitucionalização. A proposta de reformulação assistencial e da cultura manicomial tem como temas centrais: a negação da instituição asilar, a "cidadania" do louco e os modelos assistenciais de base comunitária. A desinstitucionalização do doente mental traz em seu bojo o desafio de se dotar esse indivíduo de um mínimo de recursos vitais que lhe permitam independência para a vida diária e exercício da cidadania, resgatando sua livre gestão e seu direito de ir e vir.

Como apontam Oliveira e Alessi (2005), a influência desses movimentos de crítica à psiquiatria também foi notada no contexto social brasileiro, principalmente a partir da década de 1980, no ocaso da ditadura militar e aguda crise econômica que caracterizaram o período. A sociedade reencontrava as vias democráticas de expressão e reivindicação e, neste contexto, as idéias de Foucault (2005), Goffman (1996), Szasz (1961), Laing (1969, 1982), Scheff (1966); Basaglia (1981) e outros tiveram uma forte influência. ${ }^{4}$ A situação crítica em que se encontrava a assistência psiquiátrica brasileira nessa época era favorável à crítica proposta por esses pensadores e por esses movimentos sociais.

A Reforma Psiquiátrica tem sido vista como um movimento, um processo histórico que se constitui pela crítica ao paradigma médico-psiquiátrico e pelas práticas que transformam e superam esse paradigma, no contexto brasileiro, embora com particularidades regionais significativas, no amplo espaço geográfico nacional. ${ }^{5}$ Pode-se dizer que a reforma diz respeito, necessariamente, a uma mudança nas políticas públicas de saúde mental, no sentido de priorizar o atendimento comunitário do paciente psiquiátrico em detrimento da internação asilar: do tratamento da doença mental no hospício para a reinserção social do usuário na comunidade. Isto implica na provisão de incentivos para o uso de recursos extra-hospitalares, prezando pela manutenção do portador de transtorno mental em seu meio familiar e comunitário.

\footnotetext{
3 Para um mapeamento dos movimentos reformistas da psiquiatria na contemporaneidade ver Amarante (2003).

4 Para uma visão dos estudos sociológicos sobre doença mental e da antipsiquiatria ver Brown (1973), Cooper (1971) e Sedgwick (1982).

5 Uma análise detalhada da trajetória da reforma psiquiátrica no Brasil é apresentada por Amarante (2003).
} 
Em função do compromisso firmado pelo Brasil na Declaração de Caracas ${ }^{6}$ e pela realização da II Conferência Nacional de Saúde Mental, passaram a entrar em vigor no país, a partir da década de 1990, as primeiras normas federais regulamentando a implantação dos serviços de atenção diária, fundadas nas experiências dos primeiros CAPS, NAPS e Hospitais-dias. Também foram aprovadas as primeiras normas para fiscalização e classificação dos hospitais psiquiátricos. As macro-mudanças legislativas, jurídicas e administrativas foram, no período de institucionalização da Reforma Psiquiátrica, consideradas necessárias e, até mesmo, as garantias de operacionalizaçáo de novas práticas terapêuticas. No contexto da reforma psiquiátrica, duas leis consolidaram a direção da política de saúde mental no Brasil, no sentido da desospitalização da assistência psiquiátrica, atendimento na comunidade e respeito aos direitos humanos do paciente: a Lei Federal no ${ }^{\circ}$ 10.216, de abril de 2001, com base na famosa "Lei Paulo Delgado", sobre a extinção dos manicômios, criação de serviços substitutivos na comunidade e regulação da internação psiquiátrica compulsória; e a Lei Federal no. 10.708, de julho de 2003, instituindo o Programa de Volta para Casa (conhecida como "Bolsa-Auxílio"), que assegura recursos financeiros que incentivam a saída de pacientes com longo tempo de internação dos hospícios para a família ou comunidade. ${ }^{7}$

O período atual caracteriza-se por dois movimentos simultâneos: a construção de uma rede de atenção à saúde mental substitutiva ao modelo centrado na internação hospitalar; e a fiscalização e redução progressiva e programada dos leitos psiquiátricos existentes. Embora a reforma psiquiátrica esteja consolidada desde $2001^{8}$ como política oficial do governo, e se observe uma clara reversão dos recursos gastos com hospitais psiquiátricos para os serviços extra-hospitalares, em 2004, os gastos com hospitais psiquiátricos ainda representavam quase $64 \%$ do total de recursos destinados aos serviços de saúde mental (ver Quadro 1).

\section{Quadro 1}

Proporção dos Recursos do SUS destinados aos Hospitais Psiquiátricos e aos Serviços Extra-Hospitalares nos anos de 1997, 2001 e 2004

\begin{tabular}{|l|c|c|c|}
\hline Composiçáo de gastos & $\mathbf{1 9 9 7}$ & $\mathbf{2 0 0 1}$ & $\mathbf{2 0 0 4}$ \\
\hline \% Gastos Hospitalares em Saúde Mental & 93,14 & 79,54 & 63,84 \\
\% Gastos Extra-hospitalares em Saúde Mental & 9,86 & 20,46 & 36,16 \\
\hline Total & 100 & 100 & 100 \\
\hline
\end{tabular}

Fonte: Ministério da Saúde (2005)

${ }^{6} \mathrm{O}$ principal documento norteador das políticas adotadas pelo governo brasileiro nesta área tem sido a declaração de Caracas, aprovada em 1990. Este documento estabeleceu a diretriz da saúde mental, centrando-a na comunidade e dentro de sua rede social. Os recursos, cuidados e tratamentos devem salvaguardar a dignidade pessoal e direitos civis e humanos, propiciando a permanência do doente em seu meio comunitário (Dunker e Kyrillos Neto, 2004: 119).

7 O período 1990-2003 concentra a máxima intensidade política e normativa do que chamamos, no Brasil, de Reforma Psiquiátrica. Para uma visão do conjunto de normativo no período, ver publicado do Ministério da Saúde (2004a), que se constitui em uma antologia de documentos legais, capaz de ajudar na compreensão do esforço de construção da agenda de saúde mental do SUS.

8 As Conferências Nacionais de Saúde Mental, e em especial, a III Conferência Nacional de Saúde Mental, realizada ao final de 2001 em Brasília, consolidaram a Reforma Psiquiátrica como política oficial do SUS e propuseram a criação de uma rede articulada e comunitária de cuidados com pessoas com transtornos mentais, conferindo aos CAPS o valor estratégico para a mudança do modelo de assistência. 
A partir de 2003, na gestão presidencial do Governo Lula, o processo de desinstitucionalização de pessoas com longo período de internação psiquiátrica vem avançando significativamente, graças à criação de alguns mecanismos para a redução de leitos no país e a expansão de serviços substitutivos, levando ao fechamento de vários hospitais psiquiátricos. Dentre estas medidas salientam-se: o Programa Nacional de Avaliação do Sistema Hospitalar/Psiquiatria (PNASH/Psiquiatria), que permite aos gestores um diagnóstico da qualidade da assistência dos hospitais psiquiátricos conveniados e públicos existentes na rede de saúde, descredenciando os hospitais considerados de baixa qualidade; o Programa Anual de Reestruturação da Assistência Hospitalar Psiquiátrica no SUS (PRH), que tem como principal estratégia a redução progressiva e planejada de leitos de macro-hospitais (acima de 600 leitos) e hospitais de grande porte ( 240 a 600 leitos psiquiátricos); e os Serviços Residenciais Terapêuticos (também chamados Residências Terapêuticas ou simplesmente moradias) que devem ser utilizadas para resolver o problema de moradia de pessoas com transtornos mentais graves, preferencialmente as egressas de hospitais psiquiátricos, devendo auxiliar o morador em seu processo de reintegração na comunidade.

No Quadro 2, pode-se acompanhar a reduçáo de leitos e a concomitante expansão dos CAPS, considerados serviços estratégicos da Reforma Psiquiátrica no Brasil. O destaque dado aos CAPS na atual política de saúde mental pode ser avaliado pela evolução do número destes serviços.

\section{Quadro 2}

Comparação na evolução do sistema hospitalar (número de leitos em Hospitais Psiquiátricos SUS) e serviços substitutivos (CAPS) no Brasil, 1996-2005

\begin{tabular}{|l|r|r|r|r|r|r|r|r|r|r|}
\hline Ano & $\mathbf{1 9 9 6}$ & $\mathbf{1 9 9 7}$ & $\mathbf{1 9 9 8}$ & $\mathbf{1 9 9 9}$ & $\mathbf{2 0 0 0}$ & $\mathbf{2 0 0 1}$ & $\mathbf{2 0 0 2}$ & $\mathbf{2 0 0 3}$ & $\mathbf{2 0 0 4}$ & $\mathbf{2 0 0 5}$ \\
\hline CAPS & 92 & 112 & 148 & 179 & 208 & 295 & 424 & 500 & 605 & 689 \\
\hline Leitos HP & 72.514 & 71.041 & 70.323 & 66.393 & 60.868 & 52.962 & 51.393 & 48.303 & 45.814 & 42.076 \\
\hline
\end{tabular}

Fonte: Ministério da Saúde (2005). Dados de 2005 colhidos até outubro de 2005.

Em uma rápida avaliação do processo aqui historiado, pode-se perceber que a reforma psiquiátrica brasileira tem se apresentado de forma positiva e bem sucedida. Embora ainda esteja em processo de construção, os fatos e dados aqui apresentados demonstram que ela vem alcançando seus objetivos, especialmente no que tange a provisão de recursos extra-hospitalares e na redução da internação asilar. Um dos êxitos das políticas de saúde mental atual foi ter conseguido o redirecionamento do financiamento público e um maior controle sobre o funcionamento dos hospitais. O que se espera também é que, além de promover um aperfeiçoamento técnico e institucional do tratamento da saúde mental, a reforma psiquiátrica no Brasil tenha efeitos positivos também do ponto de vista da saúde, da qualidade de vida e da cidadania de portadores de transtorno mental.

Conforme afirma Tenório (2002: 31), o lugar estratégico que a expressão 'saúde mental' ocupa hoje no discurso da reforma está relacionado a dois aspectos: servir para denotar um afastamento da figura médica da doença, que não leva em consideração os aspectos subjetivos ligados à existência concreta do sujeito assistido; e servir para demarcar um campo de práticas e saberes que não se restringem à medicina e aos saberes psicológicos tradicionais. O cuidado na saúde mental amplia-se no sentido de ser também uma sustentação cotidiana da lida diária do paciente, inclusive nas suas relaçóes sociais. A reformulação das institui- 
çóes de cuidados, segundo Goldenberg (1994: 21) depende também de uma reformulação conceitual: a doença mental não é meramente uma questão de sintomas e de sua remissão, mas uma questão de existência da pessoa doente. Uma vez que a condição psicótica abarca a totalidade da experiência do sujeito, desde questóes objetivas, como trabalhar, manter moradia, etc., até a dimensão subjetiva, uma abordagem sintomatológica da doença mental deve ser transformada "em benefício da criação de uma clínica psiquiátrica renovada, deslocando o processo de tratamento da figura da doença para a pessoa doente".

\section{A rede de cuidados na Comunidade e o papel estratégico dos Centros de Atençáo Psicossocial (CAPS)}

A rede de atenção à saúde mental brasileira é parte integrante do Sistema Único de Saúde (SUS), rede organizada de açóes e serviços públicos de saúde, instituída no Brasil por Lei Federal na década de 1990. O SUS regula e organiza em todo território nacional as açôes e serviços de saúde de forma regionalizada, hierarquizada, em níveis de complexidade crescente, tendo direção única em cada esfera de governo: federal, estadual e municipal. O SUS tem como princípios o acesso universal público e gratuito às açóes e serviços de saúde; a integralidade das ações, num conjunto articulado e contínuo em todos os níveis de complexidade do sistema; a equidade da oferta de serviços, sem preconceitos ou privilégios de qualquer espécie; a descentralização político-administrativa; o controle social das açôes, exercido por Conselhos Municipais, Estaduais e Nacional de Saúde. Compartilhando destes princípios, a rede de atenção à saúde mental, caracteriza-se por ser essencialmente pública, de base municipal.

A substituição do modelo hospitalocêntrico e segregador tem se dado através da criação e fortalecimento de uma rede de serviços substitutivos ao modelo asilar, como CAPS, Núcleos de Atenção Psicossocial (NAPS), Hospitais-Dia, Serviços Residenciais Terapêuticos, Centros de Convivência, Serviço de Urgência e Emergência Psiquiátrica em Pronto-Socorro Geral, etc. ${ }^{9}$ A Portaria no 336/2002 reconhece os CAPS como os mais representativos destes serviços e ampliou o seu funcionamento e a sua complexidade. A missão dos CAPS, segundo essa portaria é

“...dar atendimento diuturno às pessoas que sofrem com transtornos mentais severos e persistentes, num dado território, oferecendo cuidados clínicos e de reabilitaçáo psicossocial, com o objetivo de substituir o modelo hospitalacêntrico, evitando internaçóes e favorecendo o exercício da cidadania e da inclusão social dos usuários e de suas famílias" (Ministério da Saúde, 2004b: 12).

Os CAPS se diferenciam em tamanho e complexidade e quanto à especificidade da demanda. Estes estão estabelecidos em três níveis: CAPS 1 e CAPS II (para atendimento diário de adultos) e CAPS III (para atendimento diário e noturno de adultos), definidos por ordem crescente de porte, complexidade e abrangência populacional. Os CAPSi são destinados ao tratamento de crianças e adolescentes com transtornos mentais e os CAPSad

9 Várias destas experiências estão apresentas em um documento organizado pelo Ministério da Saúde (2002), intitulado como "Experiências Inovadoras no SUS". 
são destinados à população com transtornos mentais decorrentes do uso e dependência de substâncias psicoativas, como álcool e outras drogas. Este último possui leitos de repouso com a finalidade exclusiva de tratamento de desintoxicaçáo.

As inspiraçóes para os primeiros CAPS e os demais que se criaram a seguir vieram, em grande parte, das experiências realizadas no exterior, principalmente de alguns princípios das comunidades terapêuticas, da psiquiatria do setor e da psiquiatria democrática italiana. A inspiração mais forte, no entanto, segundo Pitta (1994), foi a dos Centros de Atenção Psicossocial de Manágua (Nicarágua), surgidos em 1986, em plena revolução naquele país. Esses centros se constituíram de formas criativas de cuidar de pessoas com problemas psiquiátricos. Eram utilizados líderes comunitários, profissionais diversos, materiais improvisados e sucatas para reabilitar as pessoas que, pelos transtornos mentais, eram excluídos da sociedade. As equipes eram interdisciplinares e tinham a proposta de uma ação ligada, ao mesmo tempo, à prevenção, tratamento e reabilitação. Havia ainda a parceria com outras instâncias sociais, alguns destes centros funcionavam em salóes paroquiais ou outros locais da comunidade. O que marcava essas estruturas era o compromisso ético de que todos têm direito a uma vida digna a despeito da doença mental ou de outras limitaçóes sociais e econômicas.

Para a consolidação da reforma psiquiátrica tem sido fundamental a construção de uma rede comunitária de cuidados. De acordo com documentos oficiais do Ministério da Saúde, essa rede é maior do que o conjunto dos serviços de saúde mental no município. Uma rede se conforma na medida em que são permanentemente articuladas outras instituiçóes, associaçóes, cooperativas e variados espaços das cidades. A idéia fundamental aqui é que somente uma organização em rede, e não apenas um serviço ou equipamento, é capaz de fazer face à complexidade das demandas de inclusão de pessoas secularmente estigmatizadas, em um país com acentuadas desigualdades sociais. Acredita-se que é a articulação em rede de diversos equipamentos da cidade, e não apenas os serviços de saúde, que pode garantir a resolutividade, promoçáo da autonomia e da cidadania de pessoas com transtornos mentais.

O termo Reabilitação Psicossocial tem sido utilizado para definir o modelo das práticas empregadas nos novos serviços existentes no Brasil. Segundo a International Association of Psychossocial Rehabilitation Services (Pitta, 1996), a definição clássica seria

"O processo de facilitar ao indivíduo com limitaçôes, a restauração, no melhor nível possível de autonomia do exercício de suas funçôes na comunidade. O processo enfatizaria as partes mais sadias e a totalidade de potenciais do indivíduo, mediante uma abordagem compreensiva e um suporte vocacional, residencial, social, recreacional, educacional, ajustados a demandas singulares de cada indivíduo e cada situação de modo personalizado”.

Os CAPS têm como um de seus pilares básicos a responsabilização pela clientela atendida de forma que esta se torne capaz de estabelecer laços sociais enfraquecidos por longos anos de hospitalização, ao mesmo tempo em que deve funcionar como um local de referência para seus usuários. Neste sentido, quando se pensa em um CAPS como um local de passagem, capaz de aumentar o poder contratual de seus usuários de forma que estes sejam capazes de gerar normas para suas vidas e utilizar cada vez menos os serviços, torna-se imprescindível à construção de uma rede de vínculos composta por outras instâncias da vida social. Ao mesmo tempo, por fazer parte de um sistema de saúde, os CAPS precisam articular-se a essa rede de cuidados a fim de garantir a referência para aqueles usuários que não 
necessitam de atenção diária ou estão impossibilitados de obtê-la pela insuficiente oferta de serviços substitutivos. A construção de uma rede no "interior do SUS" e no "exterior do manicômio" é um dos desafios que se apresenta aos novos dispositivos de atenção à saúde mental cujas funçôes deveriam estar além da assistência stricto sensu (Almeida, 2002: 20).

Como se pode observar a partir do exposto aqui, qualquer tentativa de avaliação dos novos serviços não poderá se basear apenas nos indicadores utilizados no modelo médico e hospitalar tradicional. Embora não exista consenso quanto à melhor forma de se avaliar os resultados dos novos serviços, os modelos utilizados deverão ser capazes de refletir de forma fiel sua prática e incluir a avaliação de conceitos importantes na sua operacionalização, tais como autonomia, qualidade de vida e inserção social do portador de transtorno mental.

\section{Consideraçóes Finais}

A avaliação dos serviços de saúde mental ainda é um campo de estudos bastante recente no Brasil. Alguns estudos realizados (Pitta et al. 1995; Silva Filho et al, 1996, 1998; Bandeira et al. 1999, 2000; Libério, 1999) procuraram criar novos instrumentos e indicadores de avaliação capazes de superar os tradicionalmente utilizados pela clínica psiquiátrica, tais como número de consultas, internaçóes ou procedimentos laboratoriais, remissão de sintomas, número de altas, diagnósticos, etc., considerados insuficientes para avaliar os serviços criados a partir do processo da Reforma Psiquiátrica. O tema da avaliação dos serviços de saúde mental ganhou destaque no Brasil principalmente a partir de meados da década de 1990, após o momento inicial dos primeiros serviços substitutivos. Estes estudos foram norteados por certa percepção da ineficiência dos indicadores tradicionais da assistência tradicional hospitalocêntrica para avaliar os novos serviços. Algumas das críticas aos processos tradicionais das formas de avaliar recaem sobre o caráter externo deste processo, a busca de objetividade como sinônimo de significância quantitativa, preocupação exclusiva com a eficiência, incapacidade de incorporar dados contextuais e baixa relevância dos resultados para os atores envolvidos na intervenção. Além disso, o campo do sofrimento psíquico e de suas formas de cuidados traz em si especificidades de ordem subjetiva e social que náo devem ser ignoradas ${ }^{10}$.

No Brasil, alguns dos estudos desenvolvidos, apoiados por organismos internacionais como a Organização Mundial de Saúde (OMS), e a presença do tema nas Conferências Nacionais de Saúde Mental, motivaram a realização de trabalhos que culminaram na validação de instrumentos adaptados à realidade brasileira. A OMS tem sido importante incentivador de pesquisas que avaliem a qualidade dos novos serviços de Saúde Mental a partir da construçáo de indicadores que captem as perspectivas dos diversos atores envolvidos: usuários, técnicos e familiares. Os instrumentos utilizados nas pesquisas buscam, a partir desta triangulação, obter dados referentes à satisfação com a assistência recebida, qualidade de vida de todos os envolvidos na atenção, níveis de autonomia e inserção social dos usuários, condiçóes de trabalho e de vida dos profissionais. O “interior” dos serviços é apontado enquanto espaço privilegiado para a produção de novas formas de avaliar. Com a incorporação de novas variáveis tais como inserção familiar, no trabalho e na vida cotidiana, busca-se responder ao desafio de criar indicadores mais sensíveis aos princípios da reforma

10 Ver, por exemplo, Amarante e Carvalho (1996), Saraceno et al (1993) e Vasconcelos (1995). 
psiquiátrica e que possam ser úteis ao processo decisório, especialmente nos locais onde ocorre a assistência (Almeida, 2002: 50). Neste sentido, vários instrumentos têm sido construídos (predominantemente por médicos) para avaliar a qualidade de vida ${ }^{11}$ de pacientes egressos de longo tempo de hospitalização.

$\mathrm{O}$ interesse na qualidade de vida nos cuidados com a saúde mental tem sido estimulado pela desinstitucionalização de pacientes psiquiátricos, como também pelo interesse em se entender como os novos modelos de atenção e cuidado aos portadores de transtornos mentais têm impactado no conjunto de suas vidas diárias. Vários instrumentos têm sido construídos para avaliar tanto os sintomas quanto o nível de funcionamento, capacidade de adaptação social e qualidade de vida do paciente crônico ${ }^{12}$. Um aspecto importante a considerar sobre estes instrumentos é que a maior parte foi construída por médicos, raramente sendo incluídos sociólogos ou antropólogos. Conseqüentemente, as percepçóes biomédicas de saúde, de bem-estar e qualidade de vida têm uma grande influência na construção destes instrumentos. Apesar da importância destes instrumentos, deve-se ponderar que a percepção biomédica necessita ser aliada às variáveis de caráter social, considerando-se os efeitos esperados em termos de inclusão social e de construção da cidadania do portador de transtorno mental.

Uma questão central na avaliação da qualidade de vida na psiquiatria é se os pacientes psiquiátricos, na medida em que suas funçôes mentais estão doentes, estariam em condiçôes de avaliar sua qualidade de vida. Um paciente com humor depressivo pode ter o humor afetado pelo negativismo, tendo uma tendência a se sentir insatisfeito com a maior parte dos aspectos de sua vida. Entretanto, se consideramos o conceito de qualidade de vida como algo subjetivo, o ponto de vista do paciente deve ser válido, podendo ser útil para avaliar sua resposta ao tratamento ${ }^{13}$.

A precária institucionalidade no Brasil em relação à avaliação de políticas e programas reflete-se também na área de saúde mental, observando-se a inexistência de consenso quanto a melhor forma de avaliar os serviços comunitários da saúde mental e aos indicadores a serem utilizados. Desta forma, este ainda é um campo aberto à inovação no que se refere ao desenvolvimento de metodologias de avaliação que possam orientar a prática diária e que não se constituam simplesmente de instrumentos de caráter burocrático.

Tendo como referência a experiência da "Instituição Negada" (Basaglia, 1981), o modelo a ser construído para a avaliação dos Serviços de Saúde Mental não levar em consideração

${ }^{11}$ O termo qualidade de vida como vem sendo aplicado na literatura médica não parece ter um único significado. "Condiçốes de saúde", "funcionamento social" e "qualidade de vida" têm sido usados como sinônimos. Qualidade de vida relacionada com a saúde e Estado subjetivo de saúde são conceitos afins centrados na avaliação subjetiva do paciente, mas necessariamente ligados ao impacto do estado de saúde sobre a capacidade do indivíduo viver plenamente. O modelo de qualidade de vida relacionado à saúde, desenvolvido por Parsons (1958, apud Lima, 2002: 15) o define como "um estado de capacidade absoluta para a realização de tarefas" e a doença só se torna um problema quando ela afeta a capacidade de desempenho.

12 Para uma discussão dos instrumentos utilizados para a mensuração da qualidade de vida de pacientes psiquiátricos ver Fonte (2006), Dias e Monteiro (2002), Lima (2002) e Pitta (1999).

13 Spitzer e colaboradores (1995 apud Lima, 2002: 28) compararam a qualidade de vida relacionada à saúde em pacientes com transtornos psiquiátricos e pacientes com outras condiçôes médicas que procuravam serviços primários. Os resultados do estudo mostraram que as doenças mentais, particularmente a depressão, contribuíram para maiores prejuízos na qualidade de vida do que outras condiçóes médicas, em todos os domínios analisados. Quanto a padrôes distintos de prejuízos na qualidade de vida, observou-se que a depressão afeta globalmente os domínios e que os pacientes que apresentavam dois ou mais transtornos, tiveram os piores escores de qualidade de vida. 
apenas a supressão ou redução dos sintomas. Deve-se avaliar também a inserção familiar, no trabalho e na vida cotidiana do portador de transtorno mental, consideradas de difícil mensurabilidade. Os serviços substitutivos apresentam-se como uma realidade muito recente e ainda não hegemônica em termos de destinação de recursos relativos à assistência psiquiátrica no Brasil. Modelos avaliativos ainda são incipientes e a assistência ao louco envolve determinantes sociais e individuais complexos. Entretanto, o desenvolvimento de políticas que pressupóem a participação popular, especialmente aquelas relacionadas a grupos sociais vulneráveis, faz crescer a necessidade de avaliaçóes que, além de incorporem a perspectiva dos usuários e dos demais envolvidos, ampliem a visibilidade das novas práticas.

\section{Referências Bibliográficas}

AMARANTE, Paulo - Loucos pela Vida: a trajetória da Reforma Psiquiátrica no Brasil. Rio de Janeiro: Panorama/ Fiocruz, 2003.

AMARANTE, Paulo; CARVAlHO, A. L. - "Avaliação de qualidade dos novos serviços de Saúde Mental: em busca de novos parâmetros". Saúde em Debate. 52, 1996, pp. 74-82.

ALMEIDA, P. F. - O desafio da produção de indicadores para avaliação dos serviços de saúde mental: um estudo do Centro de Atenção Psicossocial Rubens Correia/RJ. Rio de Janeiro: Fundação Oswaldo Cruz / Escola Nacional de Saúde Pública. Dissertação de Mestrado, 2002.

BANDEIRA, Marina et al. - "Escalas da OMS de avaliação da satisfação e da sobrecarga em serviços de saúde mental: qualidades psicométricas da versão brasileira”. Jornal Brasileiro Psiquiatria, 48 (6), 1999, pp. 233-244.

BASÁGLIA, Franco - A Instituição Negada. Rio de Janeiro: Ed.Graal, 1981.

BROWN, Phil (Ed.) - Radical Psychology. London: Tavistock, 1973.

COOPER, David - Psychiatry and anti-psychiatry. New York: Ballantine Books, 1971.

DUNKER, C. I. L.; KYRILLOS NETO, Fuad - "Sobre a retórica da exclusão: a incidência do discurso ideológico em serviços substitutivos de cuidados psicóticos”. Psicologia, Ciência e Profissáo. 24 (1), 2004, pp. 116-125.

DIAS, Miriam T. Guterres; MONTEIRO, Jaqueline R. - "Seguimento e avaliação da reforma Psiquiátrica no Hospital Psiquiátrico São Pedro”. In: Experiências inovadoras no SUS.: Relatos de experiências: novas tecnologias assistenciais / Secretaria Estaduais e Municipais de Saúde / Secretaria de Assistência à Saúde / Secretaria de Gestão e Investimento em Saúde (Projeto REFORSUS). Brasília: Ministério da Saúde, 2002.

FIRMINO, Hiran - Nos poróes da loucura. Rio de Janeiro: Codecri, 1982.

FONTE, Eliane da - "Saúde mental e cidadania: a qualidade de vida em portadores de transtorno mental". In Fontes, Breno e Martins, Paulo Henrique (org.) Redes, práticas associativas e gestão pública. Recife: Ed. Universitária da UFPE, 2006.

FOUCAULT, Michel - História da Loucura. São Paulo: Perspectiva, 2005.

GOFFMAN, Erving - Manicômios, prisóes e conventos. São Paulo: Perspectiva, 1996.

GOLDENBERG, Jairo - Clínica da Psicose: um projeto na rede pública. Rio de Janeiro: Te-Corá / Instituto Franco Basaglia, 1994.

LAING, Ronald David - Politics of Experience. Harmondsworth: Penguin, 1969.

LAING, Ronald David - Sobre loucos e sãos. São Paulo: Brasiliense, 1982.

LIBÈRIO, Maria Madalena - Estudo de Satisfaçáo com os CAPS da Cidade do Rio de Janeiro: ouvindo seus atores principais. Rio de Janeiro: Fundaçáo Oswaldo Cruz / Escola Nacional de Saúde Pública. Dissertação de Mestrado, 1999.

LIMA, A. F. B. - Qualidade de Vida em pacientes do sexo masculino dependentes de álcool. Porto Alegre, Universidade Federal do Rio Grande do Sul / Programa de Pós-Graduação em Medicina: Clínica Médica. Dissertação de Mestrado, 2002.

MINISTÉRIO DA SAÚDE/BRASIL - Reforma Psiquiátrica e Política de Saúde Mental no Brasil. Brasília: Ministério da Saúde / Secretaria de Atenção à Saúde / DAPE / Coordenação Geral de Saúde Mental. Documento apresentado à Conferência Regional de Reforma dos Serviços de Saúde Mental: 15 anos depois de Caracas. OPAS, 2005.

MINISTÉRIO DA SAÚDE/BRASIL - Legislação em Saúde Mental: 1990-2004. Brasília: Ministério da Saúde / Secretaria Executiva / Secretaria de Atenção à Saúde, 2004a. 
MINISTÉRIO DA SAÚDE/BRASIL - Saúde Mental no SUS: Os Centros de Atençâo Psicossocial. Brasília: Ministério da Saúde/ Secretaria de Atenção à Saúde / DAPE, 2004b.

MINISTÉRIO DA SAÚDE/BRASIL - Experiências inovadoras no SUS: Relatos de experiências: Novas tecnologias assistenciais. Brasília: Ministério da Saúde / Secretaria Estaduais e Municipais de Saúde / Secretaria de Assistência à Saúde / Secretaria de Gestão e Investimento em Saúde (Projeto Reforsus - Componente II), 2002.

OLIVEIRA, Alice Guimarães Bottaro de; ALESSI, Neiry Primo - "Cidadania: instrumento e finalidade do processo de trabalho na reforma psiquiátrica”. Ciência e Saúde Coletiva. Jan./Mar. 10 (1), 2005, pp. 191-203.

PITTA, Ana Maria Fernandes - "A qualidade de vida de clientes de serviços de saúde mental”. Revista de Psicologia Clínica. Edição Especial, 1999, pp. 68-77.

PITTA, Ana Maria Fernandes - “Os Centros de Atenção Psicossocial: Espaços de Reabilitação?”. Jornal Brasileiro de Psiquiatria. 43 (12), 1996, pp. 647-648.

PITTA, Ana Maria Fernandes - "Qualidade de serviços de saúde mental: desafios para e epidemiologia”. Jornal Brasileiro de Psiquiatria. 45 (6), 1994, pp. 313-321.

PITTA, Ana Maria Fernandes et al. - "Determinantes da qualidade de serviços de saúde mental em municípios brasileiros". Jornal Brasileiro de Psiquiatria. 44 (9), 1995, pp. 441-452.

SARACENO, B. et al. - Evaluation of Psychiatric Services: Hard and Soft Indicators in Inovative Approaches in Service Evaluations: Consumer Contribution to Qualitative Evaluation - Soft Indicators. Geneva: WHO/ MND/93.19, 1993.

SCHEFF, Thomas - Being Mentally Ill: A sociological Theory. Chicago: Aldine, 1966.

SEDGWICK, Peter - Psychopolitics: Laing, Foucault, Goffman, Szasz and the future of Mass Psychiatry. New York: Harper and Row, 1982.

SILVA FILHO, Jorge Ferreira et al. - "Avaliaçẫo da qualidade de serviços de Saúde Mental no município de Niterói - RJ - A satisfação dos usuários como critério avaliador”. Jornal Brasileiro de Psiquiatria. 45 (7), 1996, pp. 393-402.

SZASZ, Thomas Stephen - The Myth of Mental Illness: Foundation of a Theory of Personal Conduct. New York: Hoeber-Harper, 1961.

TENÓRIO, Fernando - "A reforma psiquiátrica brasileira, na década de 1980 aos dias atuais". História, Ciências e Saúde-Manguinhos. 9 (1), 2002, pp. 25-59.

VASCONCELOS, Eduardo - "Avaliação de serviços no contexto da desinstitucionalização psiquiátrica: revisão de metodologias e estratégias de pesquisa”. Jornal Brasileiro de Psiquiatria. 44 (4), 1995, pp. 189-197. 
(Página deixada propositadamente em branco) 


\title{
Notas bIOGRÁFICAS DOS AUTORES
}

\begin{abstract}
Adriana Marrero
Doutorada em Sociologia pela Universidade de Salamanca (Espanha). Professora Agregada do Departamento de Sociologia da Faculdade de Ciências Sociais e do Departamento de Sociologia e Economia da Educaçáo da Faculdade de Humanidades da Universidade da República (Uruguai) e Investigadora de Nível II do Sistema Nacional de Investigadores. Investiga e ensina sobre teoria sociológica, sociologia da educação e desigualdades, com ênfase na classe e no género. É autora de múltiplos trabalhos nestas áreas.
\end{abstract}

\section{Aécio Gomes de Matos}

Doutorado em Psicossociologia das Organizaçóes: Université de Paris IX - Dauphine e Pós-Doutorado em Sociologia pela Universidade Paris X - Nanterre. Professor da Universidade Federal de Pernambuco e Investigador do Núcleo de Cidadania, Exclusão e Processos de Mudança (NUCEM/UFPE). Tem investigado e publicado nas áreas do desenvolvimento e dos estudos rurais, da participação e da saúde.

\section{Breno Augusto Souto Maior Fontes}

Doutorado em Estudos das Sociedades Latino-Americanas pela Universidade de Paris III (Sorbonne-Nouvelle) em 1990. Pós-Doutoramento na Harvard University (1998-1999) e na Université de Nanterre (2003). Iniciou a sua carreira Académica na Universidade Federal de Alagoas (1984-1994). Professor Adjunto da Universidade Federal de Pernambuco desde 1994, vinculado ao Programa de Pós-Graduação em Sociologia, do Departamento de Ciências Sociais. Investigador do NUCEM/ UFPE. Tem investigado e publicado sobre redes sociais, gestão urbana, capital social, participação popular e saúde.

\section{Eliane Maria Monteiro da Fonte.}

Doutorada em Sociologia pela Universidade de Londres (LSE) e Mestre em Sociologia pela Universidade Federal de Pernambuco (UFPE). Pós-doutoramento no Instituto de Sociologia da Universidade de Hamburgo, Alemanha. Professora Adjunta do Departamento de Ciências Sociais e do Programa de Pós-Graduação em Sociologia (PPGS) da UFPE, do qual foi coordenadora. Investigadora do NUCEM/ UFPE. Investiga e publica 
nas seguintes áreas: desenvolvimento rural e local, agricultura familiar, políticas sociais e métodos de pesquisa social, com especial interesse em pesquisa avaliativa.

\section{Fernando Ruivo}

Doutorado em Sociologia pela Universidade de Coimbra. Professor da Faculdade de Economia da Universidade de Coimbra e Investigador do Centro de Estudos Sociais. Co-coordenador dos Programas de Mestrado e Doutoramento "Políticas Locais e Descentralização" e "Democracia no Século XXI" da FEUC. Coordena, ainda, o Observatório dos Poderes Locais e a parte portuguesa do Curso Integrado Coimbra-Bordéus (FEUC - Institut d'Études Politiques de Bordeaux). Tem investigado sobre poder local em Portugal e numa perspectiva comparada.

\section{María Cristina Reigadas.}

Doutorada em Filosofia pela Faculdade de Filosofía e Letras, Universidade de Buenos Aires. Professora Titular Regular da Faculdade de Ciências Sociais, Universidade de Buenos Aires, da Universidade Nacional de La Plata, Argentina e de numerosas Universidades argentinas e estrangeiras. Investigadora do Instituto de Investigação em Ciências Sociais "Gino Germani", Faculdade de Ciências Sociais, Universidade de Buenos Aires. Life Member Fellow de Clare Hall, Universidad de Cambridge, Reino Unido. É especialista em filosofia política e social e em ética.

\section{Maria José Ferros Hespanha}

Médica e Investigadora do CES. Actualmente é Coordenadora Regional do Programa Rede Nacional de Cuidados Continuados. Tem publicado diversos artigos na área da Sociologia da Saúde, com especial destaque para a questão do apoio social aos idosos.

\section{Paulo Henrique Martins}

Doutorado em Sociologia pela Universidade de Paris I, Sorbonne. Pós-doutoramento na Universidade de Paris X, Nanterre. Professor Adjunto IV do Departamento de Ciências Sociais da Universidade Federal de Pernambuco (UFPE). Fundador e coordenador do Núcleo de Cidadania, Exclusão e Processos de Mudança (NUCEM). Colaborador do MAUSS (Mouvement Anti-Utilitariste dans les Sciences Sociales). Tem se dedicado a repensar as políticas públicas no contexto da mundialização, da crise do Estado e da emergência de uma sociedade civil complexa e, nos últimos anos, contribuído para a consolidação dos estudos de Sociologia da Saúde no Brasil e para a reforma do Estado e das políticas públicas nesta área.

\section{Pedro Hespanha}

Doutorado em Sociologia pela Universidade de Coimbra. Professor da Faculdade de Economia e Investigador do Centro de Estudos Sociais, onde coordena o Núcleo de Estudos sobre Cidadania e Políticas Locais. É Coordenador dos Programas de Mestrado "Políticas 
Locais e Descentralização. As Novas Áreas do Social" e "Intervenção Social, Inovação e Empreendedorismo" da FEUC. Tem investigado e publicado nas áreas dos estudos rurais, políticas sociais, sociologia da medicina, pobreza e exclusão social

\section{Sílvia Portugal}

Doutorada em Sociologia pela Universidade de Coimbra. Professora da Faculdade de Economia da Universidade de Coimbra e Investigadora do Centro de Estudos Sociais, onde integra o Núcleo de Estudos sobre Cidadania e Políticas Locais. É Co-coordenadora do Mestrado em Sociologia da FEUC. Tem pesquisado sobre os modelos de produção de bem-estar, a articulação entre sistemas formais e informais de apoio e o papel das redes sociais. 


\section{Série}

\section{Documentos}

Imprensa da Universidade de Coimbra

Coimbra University Press

2011

- $\mathrm{U}$

C • 